\title{
Werkgelegenheid en scholing 2001
}

Citation for published version (APA):

Researchcentrum voor Onderwijs en Arbeidsmarkt, ROA. (2002). Werkgelegenheid en scholing 2001:

Statistische Bijlage. Researchcentrum voor Onderwijs en Arbeidsmarkt, Faculteit der Economische

Wetenschappen. ROA Reports No. 007B https://doi.org/10.26481/umarep.2002007B

Document status and date:

Published: 01/01/2002

DOI:

10.26481/umarep.2002007B

Document Version:

Publisher's PDF, also known as Version of record

\section{Please check the document version of this publication:}

- A submitted manuscript is the version of the article upon submission and before peer-review. There can be important differences between the submitted version and the official published version of record.

People interested in the research are advised to contact the author for the final version of the publication, or visit the DOI to the publisher's website.

- The final author version and the galley proof are versions of the publication after peer review.

- The final published version features the final layout of the paper including the volume, issue and page numbers.

Link to publication

\footnotetext{
General rights rights.

- You may freely distribute the URL identifying the publication in the public portal. please follow below link for the End User Agreement:

www.umlib.nl/taverne-license

Take down policy

If you believe that this document breaches copyright please contact us at:

repository@maastrichtuniversity.nl

providing details and we will investigate your claim.
}

Copyright and moral rights for the publications made accessible in the public portal are retained by the authors and/or other copyright owners and it is a condition of accessing publications that users recognise and abide by the legal requirements associated with these

- Users may download and print one copy of any publication from the public portal for the purpose of private study or research.

- You may not further distribute the material or use it for any profit-making activity or commercial gain

If the publication is distributed under the terms of Article $25 \mathrm{fa}$ of the Dutch Copyright Act, indicated by the "Taverne" license above, 


\section{Statistische Bijlage \\ Werkgelegenheid en scholing 2001}

ROA-R-2002/7B

Researchcentrum voor Onderwijs en Arbeidsmarkt

Faculteit der Economische Wetenschappen en Bedrijfskunde Universiteit Maastricht

Maastricht, april 2002 
Niets uit deze uitgave mag worden verveelvoudigd en/of openbaar gemaakt door middel van druk, fotokopie, microfilm, of op welke wijze ook, zonder voorafgaande schriftelijke toestemming van de directeur van het Researchcentrum voor Onderwijs en Arbeidsmarkt. In geval van overname van het datamateriaal moet telkens duidelijk als bron worden vermeld: "Researchcentrum voor Onderwijs en Arbeidsmarkt" of "ROA". Van publicaties waarin gebruik wordt gemaakt van gegevens uit deze Statistische bijlage ontvangen wij gaarne een exemplaar.

Hoewel de grootst mogelijke zorg is besteed aan de inhoud van dit rapport, kan het ROA in generlei opzicht verantwoordelijkheid op zich nemen voor eventuele onvolledigheden of onjuistheden.

ISBN 90-5321-335-X

Sec02.062.doc 


\section{Inhoud}

Voorwoord

\section{Landbouw en visserij}

Tabel 1.1 Kernindicatoren

Figuur 1.1 Sectoraal risicoprofie

Tabel 1.2 Percentage werkenden dat wordt geconfronteerd met lawaai tijdens het werk, 2000

Tabel 1.3 Percentage werkenden dat gebruik maakt van gereedschap of apparaten die trilling veroorzaken, 2000

Tabel 1.4 Percentage werkenden dat kracht moet zetten tijdens het werk, 2000

Tabel 1.5 Percentage werkenden dat onder hoge tijdsdruk werkt, 2000

Tabel 1.6 Percentage werkenden dat als gevolg van klachten door lichamelijke belasting

het werk heeft verzuimd, 1999

Tabel 1.7 Percentage werkenden dat als gevolg van problemen met de werkdruk het

werk heeft verzuimd, 1999

Tabel 1.8 Informatisering, 2000

Tabel 1.9 Uitstroomrisico, gemiddeld jaarlijks percentage, 1994-1998

Tabel 1.10 Deelname aan bedrijfsopleidingen, 2000 (momentopname)

Tabel 1.11 Risicogroepen binnen de sector per risicofactor

\section{Voeding}

Tabel 2.1

Kernindicatoren

Percentage werkenden dat wordt geconfronteerd met lawaai tijdens het werk, 2000

Percentage werkenden dat gebruik maakt van gereedschap of apparaten die trilling veroorzaken, 2000

Tabel 2.4 Percentage werkenden dat kracht moet zetten tijdens het werk, 2000

Tabel 2.5

Percentage werkenden dat onder hoge tijdsdruk werkt, 2000

Percentage werkenden dat als gevolg van klachten door lichamelijke belasting het werk heeft verzuimd, 1999

Tabel 2.7 Percentage werkenden dat als gevolg van problemen met de werkdruk het werk heeft verzuimd, 1999

Tabel 2.8 Informatisering, 2000

Tabel 2.9

Uitstroomrisico, gemiddeld jaarlijks percentage, 1994-1998

Tabel 2.10 Deelname aan bedrijfsopleidingen, 2000 (momentopname)

Tabel 2.11 Risicogroepen binnen de sector per risicofactor

\section{Chemie}

Tabel 3.1

Kernindicatoren

Tabel 3.2 Percentage werkenden dat wordt geconfronteerd met lawaai tijdens het werk, 2000

Percentage werkenden dat kracht moet zetten tijdens het werk, 2000

Percentage werkenden dat onder hoge tijdsdruk werkt, 2000

Percentage werkenden dat als gevolg van klachten door lichamelijke belasting het werk heeft verzuimd, 1999

Tabel 3.7

Percentage werkenden dat als gevolg van problemen met de werkdruk het werk heeft verzuimd, 1999

Tabel 3.9 Uitstroomrisico, gemiddeld jaarlijks percentage, 1994-1998

Tabel 3.10 Deelname aan bedrijfsopleidingen, 2000 (momentopname)

Tabel 3.11

Risicogroepen binnen de sector per risicofactor

\section{Metaal en elektrotechniek}

Tabel 4.1 Kernindicatoren 
Tabel 4.3 Percentage werkenden dat gebruik maakt van gereedschap of apparaten die trilling veroorzaken, 2000

Tabel 4.4 Percentage werkenden dat kracht moet zetten tijdens het werk, 2000

Tabel 4.5 Percentage werkenden dat onder hoge tijdsdruk werkt, 2000

Tabel 4.6 Percentage werkenden dat als gevolg van klachten door lichamelijke belasting het werk heeft verzuimd, 1999

Tabel 4.7 Percentage werkenden dat als gevolg van problemen met de werkdruk het werk heeft verzuimd, 1999

Tabel 4.8 Informatisering, 2000

Tabel 4.9 Uitstroomrisico, gemiddeld jaarlijks percentage, 1994-1998

Tabel 4.10 Deelname aan bedrijfsopleidingen, 2000 (momentopname)

Tabel 4.11 Risicogroepen binnen de sector per risicofactor

\section{Overige industrie}

Tabel $5.1 \quad$ Kernindicatoren

Percentage werkenden dat wordt geconfronteerd met lawaai tijdens het werk, 2000

Percentage werkenden dat gebruik maakt van gereedschap of apparaten die trilling veroorzaken, 2000

Tabel 5.4 Percentage werkenden dat kracht moet zetten tijdens het werk, 2000

Percentage werkenden dat als gevolg van klachten door lichamelijke belasting het werk heeft verzuimd, 1999

Percentage werkenden dat als gevolg van problemen met de werkdruk het werk heeft verzuimd, 1999

Tabel 5.8 Informatisering, 2000

Tabel 5.9

Uitstroomrisico, gemiddeld jaarlijks percentage, 1994-1998

Tabel 5.10 Deelname aan bedrijfsopleidingen, 2000 (momentopname)

Tabel 5.11

Risicogroepen binnen de sector per risicofactor

\section{Energie}

Tabel 6.1

Kernindicatoren

Percentage werkenden dat wordt geconfronteerd met lawaai tijdens het werk, 2000

Tabel 6.4

Percentage werkenden dat kracht moet zetten tijdens het werk, 2000

Tabel 6.5

Percentage werkenden dat onder hoge tijdsdruk werkt, 2000

Tabel 6.6 Percentage werkenden dat als gevolg van klachten door lichamelijke belasting het werk heeft verzuimd, 1999

Tabel 6.7 Percentage werkenden dat als gevolg van problemen met de werkdruk het werk heeft verzuind, 1999

Tabel 6.8 Informatisering, 2000

Tabel 6.9 Uitstroomrisico, gemiddeld jaarlijks percentage, 1994-1998

Tabel 6.10 Deelname aan bedriffsopleidingen, 2000 (momentopname)

Tabel 6.11 Risicogroepen binnen de sector per risicofactor

\section{Bouw en onroerend goed}

Tabel 7.1 Kernindicatoren

Figuur 7.1 Sectoraal risicoprofiel

Tabel 7.2 Percentage werkenden dat wordt geconfronteerd met lawaai tijdens het werk, 2000

Percentage werkenden dat gebruik maakt van gereedschap of apparaten die trilling veroorzaken, 2000

Percentage werkenden dat kracht moet zetten tijdens het werk, 2000

Tabel 7.4

Percentage werkenden dat onder hoge tijdsdruk werkt, 2000

Tabel 7.7 Percentage werkenden dat als gevolg van problemen met de werkdruk het werk heeft verzuimd, 1999

Tabel 7.8 Informatisering, 2000 


\section{Handel en reparatie}

Tabel $8.1 \quad$ Kernindicatoren 83

Figuur 8.1 Sectoraal risicoprofiel 84

Tabel 8.2 Percentage werkenden dat wordt geconfronteerd met lawaai tijdens het werk, $2000 \quad 84$

Tabel 8.3 Percentage werkenden dat gebruik maakt van gereedschap of apparaten die trilling veroorzaken, 2000

Tabel 8.4 Percentage werkenden dat kracht moet zetten tijdens het werk, 2000

Tabel 8.5 Percentage werkenden dat onder hoge tijdsdruk werkt, 2000

Tabel 8.6 Percentage werkenden dat als gevolg van klachten door lichamelijke belasting het werk heeft verzuimd, 1999

Tabel 8.7 Percentage werkenden dat als gevolg van problemen met de werkdruk het werk heeft verzuimd, 1999

Tabel 8.8 Informatisering, 2000

Tabel $8.9 \quad$ Uitstroomrisico, gemiddeld jaarlijks percentage, 1994-1998

Tabel 8.10 Deelname aan bedriffsopleidingen, 2000 (momentopname) 91

Tabel 8.11 Risicogroepen binnen de sector per risicofactor

\section{Transport en communicatie}

Tabel 9.1 Kernindicatoren

Figuur 9.1 Sectoraal risicoprofie

Percentage werkenden dat wordt geconfronteerd met lawaai tijdens het werk, 2000

Percentage werkenden dat gebruik maakt van gereedschap of apparaten die trilling veroorzaken, 2000

Tabel 9.4 Percentage werkenden dat kracht moet zetten tijdens het werk, 2000

Tabel 9.5 Percentage werkenden dat onder hoge tijdsdruk werkt, 2000

Tabel 9.6 Percentage werkenden dat als gevolg van klachten door lichamelijke belasting het werk heeft verzuimd, 1999

Tabel 9.7 Percentage werkenden dat als gevolg van problemen met de werkdruk het werk heeft verzuimd, 1999

Tabel 9.8 Informatisering, 2000

Uitstroomrisico, gemiddeld jaarlijks percentage, 1994-1998

Tabel 9.10 Deelname aan bedrijfsopleidingen, 2000 (momentopname) 102

Tabel 9.11 Risicogroepen binnen de sector per risicofactor 103

\section{Bank- en verzekeringswezen}

Tabel 10.1 Kernindicatoren

Tabel 10.2 Percentage werkenden dat wordt geconfronteerd met lawaai tijdens het werk, 2000

Tabel 10.3 Percentage werkenden dat gebruik maakt van gereedschap of apparaten die trilling veroorzaken, 2000

Tabel 10.4 Percentage werkenden dat kracht moet zetten tijdens het werk, 2000

Percentage werkenden dat onder hoge tijdsdruk werkt, 2000

Tabel 10.6 Percentage werkenden dat als gevolg van klachten door lichamelijke belasting het werk heeft verzuimd, 1999

Tabel 10.7 Percentage werkenden dat als gevolg van problemen met de werkdruk het werk heeft verzuimd, 1999

Tabel 10.8 Informatisering, 2000

Tabel 10.9 Uitstroomrisico, gemiddeld jaarlijks percentage, 1994-1998

\section{Horeca en zakelijke dienstverlening}

Tabel 11.1 Kernindicatoren 119

Figuur 11.1 Sectoraal risicoprofiel $\quad 120$

Tabel 11.2 Percentage werkenden dat wordt geconfronteerd met lawaai tijdens het werk, $2000 \quad 120$

Tabel 11.3 Percentage werkenden dat gebruik maakt van gereedschap of apparaten die trilling veroorzaken, 2000

Tabel 11.4 Percentage werkenden dat kracht moet zetten tijdens het werk, 2000

Tabel 11.5 Percentage werkenden dat onder hoge tijdsdruk werkt, $2000 \quad 123$

Tabel 11.6 Percentage werkenden dat als gevolg van klachten door lichamelijke belasting 124

Tabel 11.7 Percentage werkenden dat als gevolg van problemen met de werkdruk het

$\begin{array}{lll}\text { Tabel } 11.8 & \text { Informatisering, } 2000 & 126\end{array}$ 
Tabel 11.9 Uitstroomrisico, gemiddeld jaarlijks percentage, 1994-1998

\section{Kwartaire diensten}

Tabel $12.1 \quad$ Kernindicatoren 131

Figuur 12.1 Sectoraal risicoprofiel

Tabel 12.2 Percentage werkenden dat wordt geconfronteerd met lawaai tijdens het werk, $2000 \quad 132$

Tabel 12.3 Percentage werkenden dat gebruik maakt van gereedschap of apparaten die trilling veroorzaken, 2000

Tabel 12.4 Percentage werkenden dat kracht moet zetten tijdens het werk, 2000

Tabel 12.5 Percentage werkenden dat onder hoge tijdsdruk werkt, 2000

Tabel 12.6 Percentage werkenden dat als gevolg van klachten door lichamelijke belasting

Tabel 12.7 Percentage werkenden dat als gevolg van problemen met de werkdruk het

$\begin{array}{lll} & \text { werk heeft verzuimd, } 1999 & 137 \\ \text { Tabel 12.8 } & \text { Informatisering, 2000 } & 138\end{array}$

Tabel 12.9 Uitstroomrisico, gemiddeld jaarlijks percentage, 1994-1998 139

Tabel 12.10 Deelname aan bedrijfsopleidingen, 2000 (momentopname) 140

Tabel 12.11 Risicogroepen binnen de sector per risicofactor 140

\section{Overheid en onderwijs}

Tabel 13.1 Kernindicatoren

Figuur 13.1 Sectoraal risicoprofie

Tabel 13.2 Percentage werkenden dat wordt geconfronteerd met lawaai tijdens het werk, 2000

Tabel 13.3 Percentage werkenden dat gebruik maakt van gereedschap of apparaten die trilling veroorzaken, 2000

Tabel 13.4 Percentage werkenden dat kracht moet zetten tijdens het werk, 2000

Tabel 13.6 Percentage werkenden dat als gevolg van klachten door lichamelijke belasting 148

Tabel 13.7 Percentage werkenden dat als gevolg van problemen met de werkdruk het

Tabel 13.8 Informatisering, 2000

Tabel 13.9 Uitstroomrisico, gemiddeld jaarlijks percentage, 1994-1998 151

Tabel 13.10 Deelname aan bedrijfsopleidingen, 2000 (momentopname) 152

Tabel 13.11 Risicogroepen binnen de sector per risicofactor 152 


\section{Voorwoord}

Werkgelegenheid en scholing 2001 en deze bijbehorende Statistische Bijlage is de vierde versie van het overzichtsrapport in het kader van het Werkgelegenheid en Scholing Observatorium (WSO) dat het Researchcentrum voor Onderwijs en Arbeidsmarkt (ROA) in opdracht van het Ministerie van Sociale Zaken en Werkgelegenheid heeft opgesteld.

Het observatorium-karakter van dit rapport wordt weerspiegeld door het grote aantal indicatoren dat de revue passeert. Deze kengetallen hebben steeds als doel opvallende factoren of ontwikkelingen te signaleren. Deze Statistische Bijlage beoogt op dit punt wederom te fungeren als een naslagwerk, waarin op systematische wijze een totaaloverzicht wordt gegeven van de in het hoofdrapport besproken indicatoren.

Uitgangspunt van zowel het hoofdrapport als deze Statistische Bijlage is dat informatie wordt gegeven over de verschillende groepen werkenden in een bepaald beroep of met een bepaalde opleidingsachtergrond werkzaam binnen een bepaalde bedrijfssector. In deze Statistische Bijlage wordt de informatie gepresenteerd naar bedrijfssector. Per bedrijfssector wordt eerst ingegaan op een aantal kernindicatoren die betrekking hebben op de sector in haar geheel. Vervolgens wordt door middel van het risicoprofiel voor de betreffende bedrijfssector in beeld gebracht in hoeverre bepaalde risicofactoren binnen de desbetreffende sector zich voordoen en in hoeverre er scholing wordt aangeboden om kwalificatieveroudering te voorkomen c.q. te beperken. Daarna wordt voor de verschillende beroeps- en opleidingssectoren binnen de desbetreffende bedrijfssector aangegeven in hoeverre de diverse risicofactoren voor deze specifieke groepen werkenden een rol spelen. Ten slotte wordt aangegeven welke groepen werkenden binnen een sector tot de doelgroepen voor het scholingsbeleid gericht op behoud van werk behoren.

De gepresenteerde indicatoren worden telkens ook kwalitatief getypeerd, uiteenlopend van 'erg laag' tot 'erg hoog'. De typeringen die daarbij worden gebruikt zijn gebaseerd op de gemiddelde score voor de totale werkzame bevolking. Dit om de vergelijkbaarheid tussen de werkenden in de verschillende sectoren mogelijk te maken. De "trends" die voor een aantal indicatoren worden vermeld hebben telkens betrekking op de periode 1998-2000. Wanneer niet kan worden voldaan aan de ondergrens voor publicatie of wanneer het gegeven onbekend is, wordt dit in de tabellen aangegeven met een -.

De projectleiding van het WSO is in handen van prof. dr. A. de Grip. Drs. J.B. van Loo en drs. J.M.A.F. Sanders speelden een centrale rol bij de uitvoering van het onderzoek en de totstandkoming van de rapportage. Aan het rapport is verder meegewerkt door R. Leclercq en S. Dijksman. Onze dank gaat bovendien uit naar de leden van de begeleidingscommissie bij het Ministerie van Sociale Zaken en Werkgelegenheid, te weten: drs. L. Bastiaansen, dr. E. Josten, drs. J. Ruitenberg en drs. F. Straatjes. 
1. Landbouw en visserij 

Tabel 1.1

Kernindicatoren

\section{Arbeidsomstandigheden}

Belastende arbeidsomstandigheden

$\begin{array}{rr}\% & \text { typering } \\ 27 & \text { hoog } \\ 33 & \text { erg hoog } \\ 67 & \text { erg hoog } \\ 14 & \text { erg laag } \\ 43 & \text { erg laag }\end{array}$

Lawaai

Trilling

Kracht zetten

Beeldschermwerk

erg laag

Verzuim vanwege lichamelijke belasting, percentage 1999

Verzuim vanwege de hoge werkdruk, percentage 1999

gemiddeld

erg laag

\section{Technologische en organisatorische ontwikkelingen}

\begin{tabular}{|c|c|c|c|c|c|c|}
\hline Organisatorische ontwikkelingen & 1992-1994* & & $4-1996^{*}$ & \multicolumn{2}{|c|}{$1996-1998^{*}$} & $1992-1998^{*}$ \\
\hline Kleine veranderingen & 8 & & 9 & & 12 & 5 \\
\hline Intensieve veranderingen & 7 & & 6 & & 8 & 3 \\
\hline Veranderingen in positie & 5 & & 38 & & 6 & 8 \\
\hline Interne reorganisaties & 14 & & 12 & & 10 & 6 \\
\hline Technologische ontwikkelingen & 1997 & 1998 & 1999 & 2000 & 2001 & $1997-2001^{*}$ \\
\hline FTE's ICT-personeel & 0,02 & 0,07 & 0,14 & 0,15 & 0,17 & 67 \\
\hline Reële automatiseringskosten (euro) & 3.900 & 7.600 & 10.100 & 9.500 & 12.100 & 33 \\
\hline Aantal PC's** & 3 & 3 & 3 & 4 & 4 & \\
\hline Aantal PC's in netwerk ${ }^{* *}$ & 2 & 2 & 2 & 2 & 2 & \\
\hline Aantal internet-PC's** & - & 1 & 1 & 2 & 2 & 21 \\
\hline 1994 & 1995 & 1996 & 1997 & 1998 & 1999 & $1994-1998$ \\
\hline Reële R\&D uitgaven & 40 & 30 & 35 & 59 & 81 & \\
\hline
\end{tabular}

Ontwikkelingen in de structuur van de werkgelegenheid

Uitstroomrisico, 1994-1998*

Verwachte uitbreidingsvraag, 2001-2006*

Flexibele arbeid, percentage 2000

\section{Scholingsdeelname}

Deelname aan bedrijfsopleidingen, percentage 2000 (momentopname)

Cursusparticipatie, percentage 1998-2000

Bron: K\&E, POLS, Automatiseringsstatistieken (allen CBS), Arbeidsaanbod- en arbeidsvraagpanel (beiden OSA), POA (ROA)

* Gemiddelde jaarlijkse percentages

** Aantal per bedrijf 


\section{Risicoprofiel}

Figuur 1.1

Sectoraal risicoprofiel

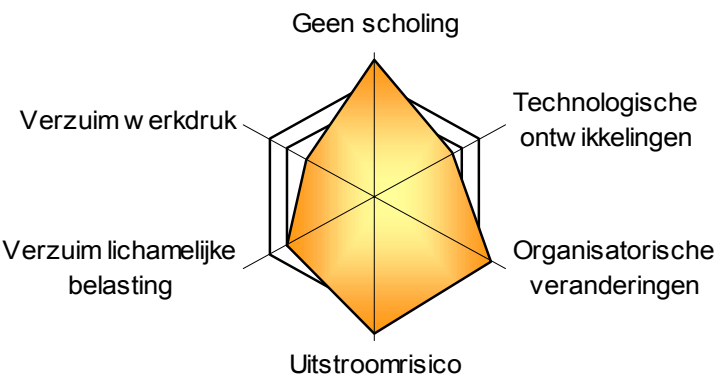

\section{Landbouw en visserij}

Uitstroomrisico

\section{Arbeidsomstandigheden}

Tabel 1.2

Percentage werkenden dat wordt geconfronteerd met lawaai tijdens het werk, 2000

\begin{tabular}{|c|c|c|c|}
\hline & $\%$ & typering & trend \\
\hline \multicolumn{4}{|l|}{ Bedrijfsgrootte } \\
\hline 5 tot 10 werknemers & 23 & gemiddeld & sterk stijgend \\
\hline 10 tot 20 & 27 & hoog & constant \\
\hline 20 tot 100 & - & gemiddeld & sterk stijgend \\
\hline 500 of meer & - & erg hoog & - \\
\hline \multicolumn{4}{|l|}{ Beroep } \\
\hline Agrarische beroepen & 27 & hoog & sterk stijgend \\
\hline Technische en Industrieberoepen & - & erg hoog & sterk stijgend \\
\hline Transportberoepen & _- & erg laag & - \\
\hline Medische en Paramedische beroepen & - & erg hoog & - \\
\hline Economisch-administratieve beroepen & - & gemiddeld & sterk stijgend \\
\hline Informaticaberoepen & - & erg laag & - \\
\hline Verzorgende en Dienstverlenende beroepen & - & erg laag & - \\
\hline \multicolumn{4}{|l|}{ Opleiding } \\
\hline Basisonderwijs & - & gemiddeld & sterk stijgend \\
\hline VMBO Theorie & 57 & erg hoog & sterk stijgend \\
\hline VMBO Landbouw en techniek & - & gemiddeld & stijgend \\
\hline VMBO Economie & - & laag & - \\
\hline VMBO Verzorging & - & erg laag & sterk stijgend \\
\hline HAVO/ VWO & - & laag & sterk dalend \\
\hline MBO Landbouw en techniek & 41 & erg hoog & stijgend \\
\hline MBO Economie & - & laag & stijgend \\
\hline MBO Dienstverlening en gezondheidszorg & - & erg hoog & sterk stijgend \\
\hline HO Landbouw en techniek & - & gemiddeld & - \\
\hline HO Economie & - & erg laag & - \\
\hline HO Onderwijs en sociaal cultureel & - & erg laag & - \\
\hline
\end{tabular}

Bron: EBB (CBS), bewerking ROA 
Tabel 1.3

Percentage werkenden dat gebruik maakt van gereedschap of apparaten die trilling veroorzaken, 2000

\begin{tabular}{|c|c|c|c|}
\hline & $\%$ & typering & trend \\
\hline \multicolumn{4}{|l|}{ Bedrijfsgrootte } \\
\hline 5 tot 10 werknemers & 36 & erg hoog & sterk stijgend \\
\hline 10 tot 20 & 29 & erg hoog & sterk stijgend \\
\hline 20 tot 100 & 34 & erg hoog & sterk stijgend \\
\hline \multicolumn{4}{|l|}{ Beroep } \\
\hline Agrarische beroepen & 34 & erg hoog & sterk stijgend \\
\hline Technische en Industrieberoepen & - & erg hoog & sterk stijgend \\
\hline Transportberoepen & - & laag & - \\
\hline Medische en Paramedische beroepen & - & laag & - \\
\hline Economisch-administratieve beroepen & - & gemiddeld & - \\
\hline Informaticaberoepen & - & laag & - \\
\hline Verzorgende en Dienstverlenende beroepen & - & laag & - \\
\hline \multicolumn{4}{|l|}{ Opleiding } \\
\hline Basisonderwijs & 31 & erg hoog & sterk stijgend \\
\hline VMBO Theorie & - & hoog & sterk stijgend \\
\hline VMBO Landbouw en techniek & 33 & erg hoog & sterk stijgend \\
\hline VMBO Economie & - & gemiddeld & - \\
\hline VMBO Verzorging & - & laag & - \\
\hline HAVO/ VWO & - & erg hoog & sterk stijgend \\
\hline MBO Landbouw en techniek & 59 & erg hoog & sterk stijgend \\
\hline MBO Economie & - & hoog & sterk stijgend \\
\hline MBO Dienstverlening en gezondheidszorg & - & hoog & sterk stijgend \\
\hline HO Landbouw en techniek & - & hoog & - \\
\hline HO Economie & - & laag & - \\
\hline HO Onderwijs en sociaal cultureel & - & laag & - \\
\hline
\end{tabular}

Bron: EBB (CBS) 
Tabel 1.4

Percentage werkenden dat kracht moet zetten tijdens het werk, 2000

\begin{tabular}{|c|c|c|c|}
\hline & $\%$ & typering & trend \\
\hline \multicolumn{4}{|l|}{ Bedrijfsgrootte } \\
\hline 5 tot 10 werknemers & 77 & erg hoog & sterk stijgend \\
\hline 10 tot 20 & 61 & hoog & stijgend \\
\hline 20 tot 100 & 60 & hoog & sterk stijgend \\
\hline \multicolumn{4}{|l|}{ Beroep } \\
\hline Agrarische beroepen & 70 & erg hoog & sterk stijgend \\
\hline Technische en Industrieberoepen & - & hoog & sterk stijgend \\
\hline Transportberoepen & - & erg hoog & - \\
\hline Medische en Paramedische beroepen & - & erg laag & - \\
\hline Economisch-administratieve beroepen & - & gemiddeld & sterk stijgend \\
\hline Informaticaberoepen & - & erg laag & - \\
\hline Sociaal-culturele beroepen & - & - & - \\
\hline Verzorgende en Dienstverlenende beroepen & - & erg hoog & sterk dalend \\
\hline \multicolumn{4}{|l|}{ Opleiding } \\
\hline Basisonderwijs & 63 & erg hoog & sterk stijgend \\
\hline VMBO Theorie & 61 & hoog & sterk stijgend \\
\hline VMBO Landbouw en techniek & 71 & erg hoog & sterk stijgend \\
\hline VMBO Economie & - & erg hoog & sterk stijgend \\
\hline VMBO Verzorging & - & hoog & sterk stijgend \\
\hline HAVO/ VWO & - & erg hoog & sterk stijgend \\
\hline MBO Landbouw en techniek & 81 & erg hoog & constant \\
\hline MBO Economie & - & hoog & sterk stijgend \\
\hline MBO Dienstverlening en gezondheidszorg & - & erg hoog & sterk stijgend \\
\hline HO Landbouw en techniek & - & laag & - \\
\hline HO Economie & - & erg laag & - \\
\hline HO Onderwijs en sociaal cultureel & - & gemiddeld & - \\
\hline
\end{tabular}

Bron: EBB (CBS) 
Tabel 1.5

Percentage werkenden dat onder hoge tijdsdruk werkt, 2000

$\% \quad$ typering trend

Bedrijfsgrootte

5 tot 10 werknemers

10 tot 20

20 tot 100

42

erg laag

stijgend

Beroep

Agrarische beroepen

Technische en Industrieberoepen

Transportberoepen

Medische en Paramedische beroepen

Economisch-administratieve beroepen

Informaticaberoepen

Sociaal-culturele beroepen

Verzorgende en Dienstverlenende beroepen

erg laag

dalend

sterk stijgend

Opleiding

Basisonderwijs

VMBO Theorie

VMBO Landbouw en techniek

VMBO Economie

VMBO Verzorging

HAVO/ VWO

MBO Landbouw en techniek

MBO Economie

41 erg laag constant

MBO Dienstverlening en gezondheidszorg

$\mathrm{HO}$ Landbouw en techniek

- laag

- $\quad$ erg laag

erg laag

- $\quad$ gemiddeld

stijgend

- $\quad$ erg laag

- $\quad$ erg laag

stijgend

- $\quad$ erg laag

erg laag sterk dalend

Economie

$46 \quad$ erg laag sterk stijgend

- $\quad$ erg laag sterk stijgend

45 erg laag dalend

- $\quad$ gemiddeld

erg laag

- $\quad$ laag

sterk stijgend

- $\quad$ erg laag

sterk stijgend

constant

erg laag dalend

HO Onderwijs en sociaal cultureel

gemiddeld

laag

sterk stijgend

sterk stijgend sterk dalend

Bron: EBB (CBS) 
Tabel 1.6

Percentage werkenden dat als gevolg van klachten door lichamelijke belasting het werk heeft verzuimd, 1999

typering

Beroep

Agrarische beroepen

Technische en Industrieberoepen

Economisch-administratieve beroepen

Verzorgende en Dienstverlenende beroepen

erg laag

- $\quad$ erg laag

Opleiding

Basisonderwijs

VMBO Theorie

VMBO Landbouw en techniek

VMBO Economie

VMBO Verzorging

HAVO/ VWO

MBO Landbouw en techniek

MBO Economie

MBO Dienstverlening en gezondheidszorg

HO Landbouw en techniek

HO Economie

HO Onderwijs en sociaal cultureel

$\mathrm{HO}$ (Para)medisch

erg hoog

erg hoog

erg laag

erg laag

erg hoog

erg laag

gemiddeld

erg laag

erg laag

erg hoog

erg hoog

erg laag

erg laag

Bron: POLS (CBS)

Tabel 1.7

Percentage werkenden dat als gevolg van problemen met de werkdruk het werk heeft verzuimd, 1999

typering

Beroep

Agrarische beroepen

Technische en Industrieberoepen

Economisch-administratieve beroepen

Verzorgende en Dienstverlenende beroepen

erg laag

erg laag

Opleiding

Basisonderwijs

VMBO Theorie

VMBO Landbouw en techniek

VMBO Economie

VMBO Verzorging

HAVO/ VWO

MBO Landbouw en techniek

MBO Economie

MBO Dienstverlening en gezondheidszorg

HO Landbouw en techniek

$\mathrm{HO}$ Onderwijs en sociaal cultureel

HO (Para)medisch

Bron: POLS (CBS) 
Technologische en organisatorische ontwikkelingen

Tabel 1.8

Informatisering, 2000

\begin{tabular}{|c|c|c|c|}
\hline & $\%$ & typering & trend \\
\hline \multicolumn{4}{|l|}{ Bedrijfsgrootte } \\
\hline 5 tot 10 werknemers & - & erg laag & constant \\
\hline 10 tot 20 & - & erg laag & sterk dalend \\
\hline 20 tot 100 & 33 & laag & sterk stijgend \\
\hline 100 tot 500 & - & erg hoog & sterk stijgend \\
\hline 500 of meer & - & erg laag & - \\
\hline \multicolumn{4}{|l|}{ Beroep } \\
\hline Agrarische beroepen & 8 & erg laag & constant \\
\hline Technische en Industrieberoepen & - & erg laag & sterk dalend \\
\hline Transportberoepen & - & erg laag & - \\
\hline Medische en Paramedische beroepen & - & erg laag & - \\
\hline Economisch-administratieve beroepen & 74 & hoog & stijgend \\
\hline Informaticaberoepen & - & erg hoog & - \\
\hline Verzorgende en Dienstverlenende beroepen & - & gemiddeld & - \\
\hline \multicolumn{4}{|l|}{ Opleiding } \\
\hline Basisonderwijs & - & erg laag & - \\
\hline VMBO Theorie & - & erg laag & dalend \\
\hline VMBO Landbouw en techniek & - & erg laag & - \\
\hline VMBO Economie & - & erg laag & - \\
\hline VMBO Verzorging & - & erg laag & - \\
\hline HAVO/ VWO & - & laag & - \\
\hline MBO Landbouw en techniek & 22 & erg laag & stijgend \\
\hline MBO Economie & - & laag & stijgend \\
\hline MBO Dienstverlening en gezondheidszorg & - & laag & - \\
\hline HO Landbouw en techniek & - & erg hoog & sterk stijgend \\
\hline HO Economie & - & erg hoog & - \\
\hline HO Onderwijs en sociaal cultureel & - & gemiddeld & _ \\
\hline
\end{tabular}

Bron: EBB (CBS)

\section{Ontwikkelingen in de structuur van de werkgelegenheid}

Tabel 1.9

Uitstroomrisico, gemiddeld jaarlijks percentage, 1994-1998

$\% \quad$ typering

Beroep

Agrarische beroepen

Technische en industrieberoepen

Economisch-administratieve beroepen

Verzorgende en dienstverlenende beroepen

gemiddeld

gemiddeld

erg hoog

Opleiding

Basisonderwijs

VMBO theorie

gemiddeld

VMBO overig

11,1 hoog

HAVO/VWO

14,9 erg hoog

$M B O$

erg

$\begin{array}{ll}3,9 & \text { gemiddeld } \\ 9,1 & \text { hoog }\end{array}$

$\mathrm{HBO}$

Bron: SEP (CBS) 


\section{Scholingsinspanningen}

Tabel 1.10

Deelname aan bedrijfsopleidingen, 2000 (momentopname)

\begin{tabular}{|c|c|c|c|}
\hline & $\%$ & typering & trend \\
\hline \multicolumn{4}{|l|}{ Beroep } \\
\hline Agrarische beroepen & - & erg laag & dalend \\
\hline Technische en Industrieberoepen & - & gemiddeld & dalend \\
\hline Transportberoepen & - & erg laag & - \\
\hline Medische en Paramedische beroepen & - & erg laag & - \\
\hline Economisch-administratieve beroepen & - & erg laag & - \\
\hline Informaticaberoepen & - & erg hoog & - \\
\hline Sociaal-culturele beroepen & - & erg laag & - \\
\hline Verzorgende en Dienstverlenende beroepen & - & erg laag & - \\
\hline \multicolumn{4}{|l|}{ Opleiding } \\
\hline Basisonderwijs & - & erg laag & sterk stijgend \\
\hline VMBO Theorie & - & erg laag & - \\
\hline VMBO Landbouw en techniek & - & erg laag & sterk dalend \\
\hline VMBO Economie & - & erg laag & - \\
\hline VMBO Verzorging & - & erg laag & - \\
\hline HAVO/ VWO & - & erg laag & - \\
\hline MBO Landbouw en techniek & - & erg laag & constant \\
\hline MBO Economie & - & erg laag & - \\
\hline MBO Dienstverlening en gezondheidszorg & - & erg laag & - \\
\hline HO Landbouw en techniek & - & erg hoog & - \\
\hline HO Economie & - & erg laag & - \\
\hline HO Onderwijs en sociaal cultureel & - & erg laag & - \\
\hline
\end{tabular}

Bron: EBB (CBS)

\section{Doelgroepen voor scholingsbeleid}

Tabel 1.11

Risicogroepen binnen de sector per risicofactor

Lichamelijke belasting

Beroep

Opleiding

Psychische belasting

Beroep

Opleiding

Informatisering

Beroep

Economische administratieve beroepen

Opleiding

Ontwikkelingen in de structuur van de werkgelegenheid Beroep

Opleiding

VMBO theorie (MAVO)

VMBO landbouw en techniek

Bron: ROA 
2. Voeding 

Tabel 2.1

Kernindicatoren

\section{Arbeidsomstandigheden}

Belastende arbeidsomstandigheden

Lawaai

Trilling

Kracht zetten

Beeldschermwerk

Tijdsdruk

$\%$

typering

Verzuim vanwege lichamelijke belasting, percentage 1999

Verzuim vanwege de hoge werkdruk, percentage 1999

erg hoog

gemiddeld

gemiddeld

gemiddeld

gemiddeld

gemiddeld

hoog

\section{Technologische en organisatorische ontwikkelingen}

Organisatorische ontwikkelingen

1992-1994*

1994-1996*

1996-1998*

$1992-1998$

Kleine veranderingen

Intensieve veranderingen

Veranderingen in positie

Interne reorganisaties

Technologische ontwikkelingen

\section{5}

28

8
10

8

$8 \quad 16$

16
9

23

21

$\begin{array}{lllll}1997 & 1998 & 1999 & 2000 & 2001\end{array}$

$\begin{array}{rrrrr}0,47 & 0,54 & 0,82 & 0,91 & 0,95 \\ 79300 & 82100 & 118200 & 129200 & 131500\end{array}$

129200131500

FTE's ICT-personeel

79300

82100118200

$\begin{array}{rrrrr}16 & 16 & 22 & 24 & 25 \\ 13 & 14 & 19 & 20 & 21 \\ - & 5 & 4 & 6 & 8\end{array}$

Aantal PC's**

Aantal PC's in netwerk**

Aantal internet-PC's**

(verandering 1998-2001)

1994

1995

1996

1997

1998

1999

Reële R\&D uitgaven

182

234

188

$180 \quad 230$

1997-2001*

Ontwikkelingen in de structuur van de werkgelegenheid

Uitstroomrisico, 1994-1998*

5,7

0,8

11

trend

dalend

typering

laag

Deelname aan bedrijfsopleidingen, percentage 2000 (momentopname)

Cursusparticipatie, percentage 1998-2000

Bron: K\&E, POLS, Automatiseringsstatistieken (allen CBS), Arbeidsaanbod- en arbeidsvraagpanel (beiden OSA), POA (ROA)

* Gemiddelde jaarlijkse percentages

** Aantal per bedrijf 


\section{Risicoprofiel}

Figuur 2.1

Sectoraal risicoprofiel

\section{Voeding}

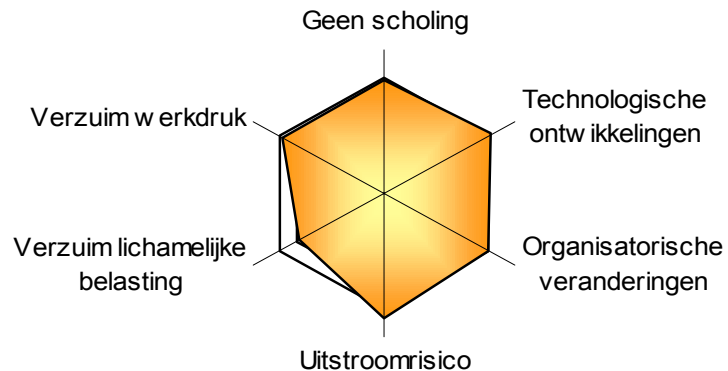

\section{Arbeidsomstandigheden}

Tabel 2.2

Percentage werkenden dat wordt geconfronteerd met lawaai tijdens het werk, 2000

\begin{tabular}{|c|c|c|c|}
\hline & $\%$ & typering & trend \\
\hline \multicolumn{4}{|l|}{ Bedrijfsgrootte } \\
\hline 5 tot 10 & - & - & sterk dalend \\
\hline 10 tot 20 & 41 & erg hoog & dalend \\
\hline 20 tot 100 & 44 & erg hoog & dalend \\
\hline 100 tot 500 & - & - & - \\
\hline 500 of meer & - & - & - \\
\hline \multicolumn{4}{|l|}{ Beroep } \\
\hline Pedagogische beroepen & - & erg laag & - \\
\hline Culturele beroepen & - & - & - \\
\hline Agrarische beroepen & _- & erg laag & _- \\
\hline Technische en Industrieberoepen & 62 & erg hoog & dalend \\
\hline Transportberoepen & - & erg hoog & sterk stijgend \\
\hline Medische en Paramedische beroepen & - & erg hoog & - \\
\hline Economisch-administratieve beroepen & 24 & gemiddeld & dalend \\
\hline Informaticaberoepen & - & gemiddeld & - \\
\hline Sociaal-culturele beroepen & - & erg laag & - \\
\hline Verzorgende en Dienstverlenende beroepen & - & gemiddeld & constant \\
\hline Openbare orde- en Veiligheidsberoepen & - & erg laag & - \\
\hline \multicolumn{4}{|l|}{ Opleiding } \\
\hline Basisonderwijs & 58 & erg hoog & constant \\
\hline VMBO Theorie & - & erg hoog & sterk dalend \\
\hline VMBO Landbouw en techniek & 57 & erg hoog & constant \\
\hline VMBO Economie & - & erg hoog & sterk stijgend \\
\hline VMBO Verzorging & - & erg hoog & sterk dalend \\
\hline HAVO/ VWO & - & erg hoog & sterk stijgend \\
\hline MBO Landbouw en techniek & 66 & erg hoog & stijgend \\
\hline MBO Economie & - & gemiddeld & sterk dalend \\
\hline MBO Dienstverlening en gezondheidszorg & - & erg hoog & dalend \\
\hline HO Landbouw en techniek & - & gemiddeld & dalend \\
\hline HO Economie & - & erg laag & - \\
\hline HO Onderwijs en sociaal cultureel & - & erg laag & - \\
\hline
\end{tabular}

Bron: EBB (CBS), bewerking ROA 
Tabel 2.3

Percentage werkenden dat gebruik maakt van gereedschap of apparaten die trilling veroorzaken, 2000

\begin{tabular}{|c|c|c|c|}
\hline & $\%$ & typering & trend \\
\hline \multicolumn{4}{|l|}{ Bedrijfsgrootte } \\
\hline 5 tot 10 & - & - & sterk stijgend \\
\hline 10 tot 20 & 24 & hoog & sterk stijgend \\
\hline 20 tot 100 & 14 & gemiddeld & constant \\
\hline \multicolumn{4}{|l|}{ Beroep } \\
\hline Pedagogische beroepen & - & laag & - \\
\hline Agrarische beroepen & - & laag & - \\
\hline Technische en Industrieberoepen & 27 & hoog & stijgend \\
\hline Transportberoepen & - & hoog & sterk stijgend \\
\hline Medische en Paramedische beroepen & - & laag & - \\
\hline Economisch-administratieve beroepen & - & laag & sterk stijgend \\
\hline Informaticaberoepen & - & laag & - \\
\hline Sociaal-culturele beroepen & - & laag & - \\
\hline Verzorgende en Dienstverlenende beroepen & - & hoog & stijgend \\
\hline Openbare orde- en Veiligheidsberoepen & - & laag & - \\
\hline \multicolumn{4}{|l|}{ Opleiding } \\
\hline Basisonderwijs & - & hoog & sterk stijgend \\
\hline VMBO Theorie & - & erg hoog & sterk stijgend \\
\hline VMBO Landbouw en techniek & - & hoog & constant \\
\hline VMBO Economie & - & erg hoog & sterk stijgend \\
\hline VMBO Verzorging & - & gemiddeld & - \\
\hline HAVO/ VWO & - & gemiddeld & - \\
\hline MBO Landbouw en techniek & 28 & erg hoog & stijgend \\
\hline MBO Economie & - & laag & - \\
\hline MBO Dienstverlening en gezondheidszorg & - & gemiddeld & - \\
\hline HO Landbouw en techniek & - & laag & - \\
\hline HO Economie & - & laag & - \\
\hline HO Onderwijs en sociaal cultureel & - & laag & - \\
\hline
\end{tabular}

Bron: EBB (CBS) 
Tabel 2.4

Percentage werkenden dat kracht moet zetten tijdens het werk, 2000

\begin{tabular}{|c|c|c|c|}
\hline & $\%$ & typering & trend \\
\hline \multicolumn{4}{|l|}{ Bedrijfsgrootte } \\
\hline 5 tot 10 & 64 & erg hoog & constant \\
\hline 10 tot 20 & 53 & hoog & sterk dalend \\
\hline 20 tot 100 & 33 & gemiddeld & dalend \\
\hline \multicolumn{4}{|l|}{ Beroep } \\
\hline Pedagogische beroepen & - & erg laag & - \\
\hline Agrarische beroepen & - & erg laag & - \\
\hline Technische en Industrieberoepen & 57 & hoog & constant \\
\hline Transportberoepen & 73 & erg hoog & dalend \\
\hline Medische en Paramedische beroepen & - & erg laag & - \\
\hline Economisch-administratieve beroepen & 15 & laag & dalend \\
\hline Informaticaberoepen & - & erg laag & - \\
\hline Sociaal-culturele beroepen & - & erg laag & - \\
\hline Verzorgende en Dienstverlenende beroepen & 44 & gemiddeld & sterk dalend \\
\hline Openbare orde- en Veiligheidsberoepen & - & erg laag & - \\
\hline \multicolumn{4}{|l|}{ Opleiding } \\
\hline Basisonderwijs & 45 & gemiddeld & sterk dalend \\
\hline VMBO Theorie & 53 & hoog & dalend \\
\hline VMBO Landbouw en techniek & 51 & hoog & sterk dalend \\
\hline VMBO Economie & - & erg hoog & sterk stijgend \\
\hline VMBO Verzorging & - & gemiddeld & dalend \\
\hline HAVO/ VWO & - & gemiddeld & sterk stijgend \\
\hline MBO Landbouw en techniek & 62 & erg hoog & stijgend \\
\hline MBO Economie & - & laag & sterk dalend \\
\hline MBO Dienstverlening en gezondheidszorg & - & gemiddeld & - \\
\hline HO Landbouw en techniek & - & laag & - \\
\hline HO Economie & - & erg laag & - \\
\hline HO Onderwijs en sociaal cultureel & - & gemiddeld & - \\
\hline
\end{tabular}

Bron: EBB (CBS) 
Tabel 2.5

Percentage werkenden dat onder hoge tijdsdruk werkt, 2000

\begin{tabular}{|c|c|c|c|}
\hline & $\%$ & typering & trend \\
\hline \multicolumn{4}{|l|}{ Bedrijfsgrootte } \\
\hline 5 tot 10 & - & erg laag & stijgend \\
\hline 10 tot 20 & 54 & laag & sterk dalend \\
\hline 20 tot 100 & 58 & gemiddeld & constant \\
\hline \multicolumn{4}{|l|}{ Beroep } \\
\hline Pedagogische beroepen & - & erg laag & - \\
\hline Agrarische beroepen & - & hoog & - \\
\hline Technische en Industrieberoepen & 54 & laag & dalend \\
\hline Transportberoepen & 58 & gemiddeld & constant \\
\hline Medische en Paramedische beroepen & - & erg laag & - \\
\hline Economisch-administratieve beroepen & 59 & gemiddeld & dalend \\
\hline Informaticaberoepen & - & erg hoog & stijgend \\
\hline Sociaal-culturele beroepen & - & erg hoog & - \\
\hline Verzorgende en Dienstverlenende beroepen & 42 & erg laag & dalend \\
\hline Openbare orde- en Veiligheidsberoepen & - & erg laag & - \\
\hline \multicolumn{4}{|l|}{ Opleiding } \\
\hline Basisonderwijs & 48 & laag & dalend \\
\hline VMBO Theorie & - & erg laag & sterk dalend \\
\hline VMBO Landbouw en techniek & 55 & gemiddeld & dalend \\
\hline VMBO Economie & - & erg hoog & sterk stijgend \\
\hline VMBO Verzorging & - & erg laag & sterk dalend \\
\hline HAVO/ VWO & - & erg laag & sterk dalend \\
\hline MBO Landbouw en techniek & 61 & gemiddeld & constant \\
\hline MBO Economie & 56 & gemiddeld & constant \\
\hline MBO Dienstverlening en gezondheidszorg & - & erg laag & sterk dalend \\
\hline HO Landbouw en techniek & - & hoog & dalend \\
\hline HO Economie & 65 & hoog & sterk stijgend \\
\hline HO Onderwijs en sociaal cultureel & - & laag & - \\
\hline $\mathrm{HO}$ (Para)medisch & - & erg hoog & - \\
\hline
\end{tabular}

Bron: EBB (CBS) 
Tabel 2.6

Percentage werkenden dat als gevolg van klachten door lichamelijke belasting het werk heeft verzuimd, 1999

typering

Beroep

Agrarische beroepen

Technische en Industrieberoepen

Transportberoepen

Economisch-administratieve beroepen

Informaticaberoepen

Verzorgende en Dienstverlenende beroepen

Openbare orde- en Veiligheidsberoepen

$\begin{array}{ll}- & \text { erg laag } \\ 6 & \text { gemiddeld } \\ - & \text { erg laag } \\ - & \text { erg laag } \\ - & \text { erg laag } \\ - & \text { erg laag } \\ - & \text { erg laag }\end{array}$

Opleiding

Basisonderwijs

VMBO Theorie

VMBO Landbouw en techniek

VMBO Economie

VMBO Verzorging

HAVO/ VWO

MBO Landbouw en techniek

MBO Economie

MBO Dienstverlening en gezondheidszorg

$\mathrm{HO}$ Landbouw en techniek

$\mathrm{HO}$ Economie

HO Onderwijs en sociaal cultureel

HO (Para)medisch

$\begin{array}{cl}31 & \text { erg hoog } \\ 19 & \text { erg hoog } \\ - & \text { erg laag } \\ - & \text { erg laag } \\ - & \text { erg laag } \\ - & \text { erg laag } \\ - & \text { erg laag } \\ - & \text { erg laag } \\ - & \text { erg laag } \\ - & \text { erg laag } \\ - & \text { erg laag } \\ - & \text { erg hoog } \\ - & \text { erg laag }\end{array}$

Bron: POLS (CBS)

Tabel 2.7

Percentage werkenden dat als gevolg van problemen met de werkdruk het werk heeft verzuimd, 1999

$\% \quad$ typering

Beroep

Agrarische beroepen

Technische en Industrieberoepen

Transportberoepen

Economisch-administratieve beroepen

Informaticaberoepen

Verzorgende en Dienstverlenende beroepen

Openbare orde- en Veiligheidsberoepen

Opleiding

Basisonderwijs

VMBO Theorie

VMBO Landbouw en techniek

VMBO Economie

VMBO Verzorging

HAVO/ VWO

MBO Landbouw en techniek

MBO Economie

MBO Dienstverlening en gezondheidszorg

HO Landbouw en techniek

HO Economie

HO (Para)medisch

$\begin{array}{ll}- & \text { erg laag } \\ 7 & \text { hoog } \\ - & \text { erg laag } \\ - & \text { erg laag } \\ - & \text { erg laag } \\ - & \text { erg laag } \\ - & \text { erg laag }\end{array}$

Bron: POLS (CBS) 
Technologische en organisatorische ontwikkelingen

Tabel 2.8

Informatisering, 2000

\begin{tabular}{|c|c|c|c|}
\hline & $\%$ & typering & trend \\
\hline \multicolumn{4}{|l|}{ Bedrijfsgrootte } \\
\hline 5 tot 10 & - & erg laag & sterk stijgend \\
\hline 10 tot 20 & 26 & laag & dalend \\
\hline 20 tot 100 & 72 & hoog & sterk stijgend \\
\hline 100 tot 500 & - & erg hoog & - \\
\hline 500 of meer & - & erg laag & - \\
\hline \multicolumn{4}{|l|}{ Beroep } \\
\hline Pedagogische beroepen & - & erg hoog & - \\
\hline Agrarische beroepen & - & laag & - \\
\hline Technische en Industrieberoepen & 50 & gemiddeld & stijgend \\
\hline Transportberoepen & - & gemiddeld & sterk stijgend \\
\hline Medische en Paramedische beroepen & - & gemiddeld & - \\
\hline Economisch-administratieve beroepen & 76 & hoog & sterk stijgend \\
\hline Informaticaberoepen & - & erg hoog & - \\
\hline Sociaal-culturele beroepen & - & erg hoog & - \\
\hline Verzorgende en Dienstverlenende beroepen & - & erg laag & sterk stijgend \\
\hline Openbare orde- en Veiligheidsberoepen & - & erg hoog & - \\
\hline \multicolumn{4}{|l|}{ Opleiding } \\
\hline Basisonderwijs & - & laag & stijgend \\
\hline VMBO Theorie & - & laag & dalend \\
\hline VMBO Landbouw en techniek & - & laag & sterk dalend \\
\hline VMBO Economie & - & laag & - \\
\hline VMBO Verzorging & - & laag & sterk stijgend \\
\hline HAVO/ VWO & - & gemiddeld & dalend \\
\hline MBO Landbouw en techniek & 67 & gemiddeld & sterk stijgend \\
\hline MBO Economie & 63 & gemiddeld & stijgend \\
\hline MBO Dienstverlening en gezondheidszorg & - & gemiddeld & constant \\
\hline HO Landbouw en techniek & 94 & erg hoog & sterk stijgend \\
\hline HO Economie & 98 & erg hoog & sterk stijgend \\
\hline HO Onderwijs en sociaal cultureel & - & erg hoog & - \\
\hline
\end{tabular}

Bron: EBB (CBS) 
Ontwikkelingen in de structuur van de werkgelegenheid

Tabel 2.9

Uitstroomrisico, gemiddeld jaarlijks percentage, 1994-1998

typering

Beroep

Technische en industrieberoepen

Transportberoepen

Economisch-administratieve beroepen

Informaticaberoepen

Verzorgende en dienstverlenende beroepen

3,4

middeld

6,3 gemiddeld

14,3 erg hoog

15,6 erg hoog

Opleiding

Basisonderwijs

VMBO theorie

10,3 hoog

VMBO overig

27,3 erg hoog

HAVO/VWO

2,5 laag

MBO

16,7

erg hoog

$\mathrm{HBO}$

gemiddeld

Bron: SEP (CBS)

\section{Scholingsinspanningen}

Tabel 2.10

Deelname aan bedrijfsopleidingen, 2000 (momentopname)

$\% \quad$ typering trend

\section{Beroep}

Pedagogische beroepen

Agrarische beroepen

Technische en Industrieberoepen

Transportberoepen

Medische en Paramedische beroepen

Economisch-administratieve beroepen

Informaticaberoepen

Sociaal-culturele beroepen

Verzorgende en Dienstverlenende beroepen

Openbare orde- en Veiligheidsberoepen

Opleiding

Basisonderwijs

VMBO Theorie

VMBO Landbouw en techniek

VMBO Economie

VMBO Verzorging

HAVO/ VWO

MBO Landbouw en techniek

MBO Economie

MBO Dienstverlening en gezondheidszorg

HO Landbouw en techniek

HO Economie

$\mathrm{HO}$ Onderwijs en sociaal cultureel

HO (Para)medisch

$\begin{array}{ll}\text { erg laag } & - \\ \text { erg hoog } & - \\ \text { gemiddeld } & \text { sterk dalend } \\ \text { laag } & - \\ \text { erg laag } & - \\ \text { erg laag } & \text { dalend } \\ \text { erg laag } & - \\ \text { erg hoog } & - \\ \text { erg laag } & - \\ \text { erg laag } & - \\ & \\ \text { erg laag } & \text { constant } \\ \text { erg laag } & \text { stijgend } \\ \text { laag } & \text { constant } \\ \text { erg laag } & - \\ \text { erg laag } & - \\ \text { erg laag } & - \\ \text { erg hoog } & \text { dalend } \\ \text { hoog } & \text { sterk dalend } \\ \text { erg laag } & \text { dalend } \\ \text { erg laag } & \text { sterk dalend } \\ \text { gemiddeld } & \text { sterk stijgend } \\ \text { erg laag } & - \\ \text { erg laag } & -\end{array}$

Bron: EBB (CBS) 


\section{Doelgroepen voor scholingsbeleid}

Tabel 2.11

Risicogroepen binnen de sector per risicofactor

\section{Lichamelijke belasting}

Beroep

Opleiding

Basisonderwijs

Psychische belasting

Beroep

Opleiding

VMBO theorie (MAVO)

Informatisering

Beroep

Opleiding

HO landbouw en techniek

Ontwikkelingen in de structuur van de werkgelegenheid Beroep

Verzorgende en dienstverlenende beroepen

Opleiding

VMBO theorie (MAVO) 

3. Chemie 

Tabel 3.1

Kernindicatoren

\section{Arbeidsomstandigheden}

Belastende arbeidsomstandigheden

Lawaai

Trilling

Kracht zetten

Beeldschermwerk

Tijdsdruk

$\begin{array}{rr}\% & \text { typering } \\ 39 & \text { erg hoog } \\ 22 & \text { hoog } \\ 34 & \text { gemiddeld } \\ 77 & \text { hoog } \\ 60 & \text { gemiddeld } \\ & \\ 10 & \text { hoog } \\ - & \text { erg laag }\end{array}$

Verzuim vanwege lichamelijke belasting, percentage 1999

Verzuim vanwege de hoge werkdruk, percentage 1999

\section{Technologische en organisatorische ontwikkelingen}

\begin{tabular}{|c|c|c|c|c|c|c|}
\hline Organisatorische ontwikkelingen & 1992-1994* & \multicolumn{2}{|c|}{$1994-1996 *$} & \multicolumn{2}{|c|}{$1996-1998^{*}$} & $1992-1998^{*}$ \\
\hline Kleine veranderingen & 17 & & 9 & & 9 & 6 \\
\hline Intensieve veranderingen & 11 & & 8 & & 13 & 5 \\
\hline Veranderingen in positie & 6 & & 21 & & 7 & 6 \\
\hline Interne reorganisaties & 12 & & 7 & & 27 & 8 \\
\hline Technologische ontwikkelingen & 1997 & 1998 & 1999 & 2000 & 2001 & $1997-2001^{*}$ \\
\hline $\begin{array}{l}\text { FTE's ICT-personeel } \\
\text { Reële automatiseringskosten (euro) }\end{array}$ & $\begin{array}{r}0,35 \\
46900\end{array}$ & $\begin{array}{r}0,45 \\
59400\end{array}$ & $\begin{array}{r}0,85 \\
63700\end{array}$ & $\begin{array}{r}0,91 \\
58600\end{array}$ & $\begin{array}{r}1,00 \\
60000\end{array}$ & $\begin{array}{r}30 \\
6\end{array}$ \\
\hline Aantal PC's** & 17 & 16 & 19 & 20 & 21 & \\
\hline Aantal PC's in netwerk ${ }^{* *}$ & 14 & 15 & 17 & 18 & 19 & \\
\hline Aantal internet-PC's** & - & 4 & 6 & 7 & 9 & 29 \\
\hline 1994 & 1995 & 1996 & 1997 & 1998 & 1999 & $1994-199$ \\
\hline Reële R\&D uitgaven & 826 & 819 & 834 & 823 & 884 & \\
\hline
\end{tabular}

Ontwikkelingen in de structuur van de werkgelegenheid

Uitstroomrisico, 1994-1998*

Verwachte uitbreidingsvraag, 2001-2006*

Flexibele arbeid, percentage 2000

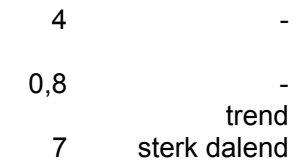

\section{Scholingsdeelname}

Deelname aan bedrijfsopleidingen, percentage 2000 (momentopname)

Cursusparticipatie, percentage 1998-2000 typering

9 erg hoog

Bron: K\&E, POLS, Automatiseringsstatistieken (allen CBS), Arbeidsaanbod- en arbeidsvraagpanel (beiden OSA), POA (ROA)

* Gemiddelde jaarlijkse percentages

** Aantal per bedrijf 


\section{Risicoprofiel}

Figuur 3.1

Sectoraal risicoprofiel

Chemie

Geen scholing

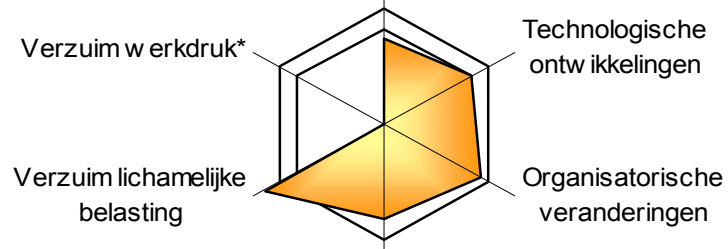

Uitstroomrisico

* geen betrouwbare informatie beschikbaar voor deze risicofactor

\section{Arbeidsomstandigheden}

Tabel 3.2

Percentage werkenden dat wordt geconfronteerd met lawaai tijdens het werk, 2000

\begin{tabular}{|c|c|c|c|}
\hline & $\%$ & typering & trend \\
\hline \multicolumn{4}{|l|}{ Bedrijfsgrootte } \\
\hline 10 tot 20 & 34 & erg hoog & dalend \\
\hline 20 tot 100 & 40 & erg hoog & dalend \\
\hline \multicolumn{4}{|l|}{ Beroep } \\
\hline Technische en Industrieberoepen & 53 & erg hoog & sterk dalend \\
\hline Transportberoepen & - & gemiddeld & sterk dalend \\
\hline Medische en Paramedische beroepen & - & gemiddeld & - \\
\hline Economisch-administratieve beroepen & - & laag & sterk stijgend \\
\hline Informaticaberoepen & - & laag & - \\
\hline Sociaal-culturele beroepen & - & erg laag & - \\
\hline Verzorgende en Dienstverlenende beroepen & - & erg hoog & - \\
\hline Openbare orde- en Veiligheidsberoepen & - & erg hoog & - \\
\hline \multicolumn{4}{|l|}{ Opleiding } \\
\hline Basisonderwijs & 58 & erg hoog & stijgend \\
\hline VMBO Theorie & - & erg hoog & sterk dalend \\
\hline VMBO Landbouw en techniek & - & erg hoog & sterk dalend \\
\hline VMBO Economie & - & erg hoog & - \\
\hline VMBO Verzorging & - & erg hoog & - \\
\hline HAVO/ VWO & - & gemiddeld & sterk dalend \\
\hline MBO Landbouw en techniek & 56 & erg hoog & sterk dalend \\
\hline MBO Economie & - & gemiddeld & sterk dalend \\
\hline MBO Dienstverlening en gezondheidszorg & - & erg hoog & sterk stijgend \\
\hline HO Landbouw en techniek & - & gemiddeld & sterk stijgend \\
\hline HO Economie & - & gemiddeld & - \\
\hline HO Onderwijs en sociaal cultureel & - & erg laag & - \\
\hline HO (Para)medisch & - & erg laag & - \\
\hline
\end{tabular}

Bron: EBB (CBS), bewerking ROA 
Tabel 3.3

Percentage werkenden dat gebruik maakt van gereedschap of apparaten die trilling veroorzaken, 2000

\begin{tabular}{|c|c|c|c|}
\hline & $\%$ & typering & trend \\
\hline \multicolumn{4}{|l|}{ Bedrijfsgrootte } \\
\hline 10 tot 20 & - & hoog & sterk dalend \\
\hline 20 tot 100 & 23 & hoog & constant \\
\hline \multicolumn{4}{|l|}{ Beroep } \\
\hline Technische en Industrieberoepen & 32 & erg hoog & dalend \\
\hline Transportberoepen & - & gemiddeld & - \\
\hline Medische en Paramedische beroepen & - & erg hoog & - \\
\hline Economisch-administratieve beroepen & - & laag & - \\
\hline Informaticaberoepen & - & laag & - \\
\hline Sociaal-culturele beroepen & - & laag & - \\
\hline Verzorgende en Dienstverlenende beroepen & - & erg hoog & - \\
\hline Openbare orde- en Veiligheidsberoepen & - & erg hoog & - \\
\hline \multicolumn{4}{|l|}{ Opleiding } \\
\hline Basisonderwijs & - & hoog & - \\
\hline VMBO Theorie & - & hoog & sterk stijgend \\
\hline VMBO Landbouw en techniek & - & erg hoog & sterk dalend \\
\hline VMBO Economie & - & erg hoog & - \\
\hline VMBO Verzorging & - & laag & - \\
\hline HAVO/ VWO & - & gemiddeld & - \\
\hline MBO Landbouw en techniek & 32 & erg hoog & sterk dalend \\
\hline MBO Economie & - & gemiddeld & stijgend \\
\hline MBO Dienstverlening en gezondheidszorg & - & erg hoog & - \\
\hline HO Landbouw en techniek & - & gemiddeld & sterk stijgend \\
\hline HO Economie & - & gemiddeld & - \\
\hline HO Onderwijs en sociaal cultureel & - & laag & - \\
\hline HO (Para)medisch & - & laag & - \\
\hline
\end{tabular}

Bron: EBB (CBS) 
Tabel 3.4

Percentage werkenden dat kracht moet zetten tijdens het werk, 2000

\begin{tabular}{|c|c|c|c|}
\hline & $\%$ & typering & trend \\
\hline \multicolumn{4}{|l|}{ Bedrijfsgrootte } \\
\hline 10 tot 20 & 48 & hoog & stijgend \\
\hline 20 tot 100 & 31 & gemiddeld & dalend \\
\hline \multicolumn{4}{|l|}{ Beroep } \\
\hline Technische en Industrieberoepen & 48 & hoog & dalend \\
\hline Transportberoepen & - & gemiddeld & sterk dalend \\
\hline Medische en Paramedische beroepen & - & laag & - \\
\hline Economisch-administratieve beroepen & - & erg laag & constant \\
\hline Informaticaberoepen & - & erg laag & - \\
\hline Sociaal-culturele beroepen & - & erg laag & - \\
\hline Verzorgende en Dienstverlenende beroepen & - & erg laag & - \\
\hline Openbare orde- en Veiligheidsberoepen & - & hoog & - \\
\hline \multicolumn{4}{|l|}{ Opleiding } \\
\hline Basisonderwijs & 66 & erg hoog & dalend \\
\hline VMBO Theorie & - & gemiddeld & dalend \\
\hline VMBO Landbouw en techniek & - & hoog & sterk dalend \\
\hline VMBO Economie & - & erg hoog & - \\
\hline VMBO Verzorging & - & hoog & sterk dalend \\
\hline HAVO/ VWO & - & erg laag & - \\
\hline MBO Landbouw en techniek & 48 & hoog & dalend \\
\hline MBO Economie & - & laag & sterk dalend \\
\hline MBO Dienstverlening en gezondheidszorg & - & gemiddeld & sterk stijgend \\
\hline HO Landbouw en techniek & - & laag & sterk stijgend \\
\hline HO Economie & - & erg laag & - \\
\hline HO Onderwijs en sociaal cultureel & - & erg laag & - \\
\hline HO (Para)medisch & - & erg laag & - \\
\hline
\end{tabular}

Bron: EBB (CBS) 
Tabel 3.5

Percentage werkenden dat onder hoge tijdsdruk werkt, 2000

\begin{tabular}{|c|c|c|c|}
\hline & $\%$ & typering & trend \\
\hline \multicolumn{4}{|l|}{ Bedrijfsgrootte } \\
\hline 5 tot 10 & - & - & sterk dalend \\
\hline 10 tot 20 & 57 & gemiddeld & dalend \\
\hline 20 tot 100 & 62 & gemiddeld & dalend \\
\hline 100 tot 500 & - & - & sterk dalend \\
\hline \multicolumn{4}{|l|}{ Beroep } \\
\hline Pedagogische beroepen & - & erg hoog & - \\
\hline Culturele beroepen & - & erg hoog & _ \\
\hline Technische en Industrieberoepen & 60 & gemiddeld & dalend \\
\hline Transportberoepen & - & erg laag & sterk dalend \\
\hline Medische en Paramedische beroepen & - & laag & sterk dalend \\
\hline Economisch-administratieve beroepen & 65 & gemiddeld & dalend \\
\hline Informaticaberoepen & - & erg hoog & sterk stijgend \\
\hline Sociaal-culturele beroepen & - & gemiddeld & - \\
\hline Verzorgende en Dienstverlenende beroepen & - & erg laag & sterk dalend \\
\hline Openbare orde- en Veiligheidsberoepen & - & gemiddeld & - \\
\hline \multicolumn{4}{|l|}{ Opleiding } \\
\hline Basisonderwijs & - & erg laag & dalend \\
\hline VMBO Theorie & - & gemiddeld & sterk dalend \\
\hline VMBO Landbouw en techniek & - & laag & sterk dalend \\
\hline VMBO Economie & - & hoog & sterk stijgend \\
\hline VMBO Verzorging & - & erg hoog & sterk dalend \\
\hline HAVO/ VWO & - & hoog & sterk dalend \\
\hline MBO Landbouw en techniek & 58 & gemiddeld & sterk dalend \\
\hline MBO Economie & 57 & gemiddeld & sterk dalend \\
\hline MBO Dienstverlening en gezondheidszorg & - & gemiddeld & sterk stijgend \\
\hline HO Landbouw en techniek & 69 & hoog & constant \\
\hline HO Economie & 80 & erg hoog & stijgend \\
\hline HO Onderwijs en sociaal cultureel & - & erg hoog & sterk dalend \\
\hline $\mathrm{HO}$ (Para)medisch & - & erg hoog & constant \\
\hline
\end{tabular}

Bron: EBB (CBS) 
Tabel 3.6

Percentage werkenden dat als gevolg van klachten door lichamelijke belasting het werk heeft verzuimd, 1999

\begin{tabular}{lcl}
\hline & $\%$ & typering \\
\hline Beroep & & \\
Technische en Industrieberoepen & 16 & erg hoog \\
Medische en Paramedische beroepen & - & erg laag \\
Economisch-administratieve beroepen & - & erg laag \\
Informaticaberoepen & - & erg laag \\
Opleiding & & \\
Basisonderwijs & - & erg laag \\
VMBO Theorie & 35 & erg hoog \\
VMBO Landbouw en techniek & 64 & erg hoog \\
VMBO Economie & - & erg laag \\
VMBO Verzorging & - & erg laag \\
HAVO/ VWO & - & erg laag \\
MBO Landbouw en techniek & 6 & gemiddeld \\
MBO Economie & - & erg laag \\
MBO Dienstverlening en gezondheidszorg & - & erg hoog \\
HO Landbouw en techniek & - & erg laag \\
HO Economie & - & erg laag \\
HO Onderwijs en sociaal cultureel & - & erg hoog \\
HO (Para)medisch & - & erg laag \\
\hline BrOn: POLS (CBS) & & \\
\hline
\end{tabular}

Bron: POLS (CBS)

Tabel 3.7

Percentage werkenden dat als gevolg van problemen met de werkdruk het werk heeft verzuimd, 1999

\begin{tabular}{|c|c|c|}
\hline & $\%$ & typering \\
\hline \multicolumn{3}{|l|}{ Beroep } \\
\hline Technische en Industrieberoepen & 3 & erg laag \\
\hline Medische en Paramedische beroepen & - & erg laag \\
\hline Economisch-administratieve beroepen & - & erg laag \\
\hline Informaticaberoepen & - & erg laag \\
\hline \multicolumn{3}{|l|}{ Opleiding } \\
\hline Basisonderwijs & 27 & erg hoog \\
\hline VMBO Theorie & - & erg laag \\
\hline VMBO Landbouw en techniek & - & erg laag \\
\hline VMBO Economie & - & erg laag \\
\hline VMBO Verzorging & - & erg laag \\
\hline HAVO/ VWO & - & erg laag \\
\hline MBO Landbouw en techniek & - & erg laag \\
\hline MBO Economie & - & erg laag \\
\hline HO Landbouw en techniek & - & erg laag \\
\hline HO Economie & - & erg laag \\
\hline $\mathrm{HO}$ (Para)medisch & - & erg laag \\
\hline
\end{tabular}

Bron: POLS (CBS) 
Technologische en organisatorische ontwikkelingen

Tabel 3.8

Informatisering, 2000

\begin{tabular}{|c|c|c|c|}
\hline & $\%$ & typering & trend \\
\hline \multicolumn{4}{|l|}{ Bedrijfsgrootte } \\
\hline 5 tot 10 & - & gemiddeld & - \\
\hline 10 tot 20 & 58 & gemiddeld & constant \\
\hline 20 tot 100 & 82 & hoog & dalend \\
\hline 500 of meer & - & hoog & - \\
\hline \multicolumn{4}{|l|}{ Beroep } \\
\hline Technische en Industrieberoepen & 73 & hoog & constant \\
\hline Transportberoepen & - & gemiddeld & dalend \\
\hline Medische en Paramedische beroepen & - & erg hoog & - \\
\hline Economisch-administratieve beroepen & 82 & hoog & dalend \\
\hline Informaticaberoepen & - & erg hoog & - \\
\hline Sociaal-culturele beroepen & - & erg hoog & - \\
\hline Verzorgende en Dienstverlenende beroepen & - & gemiddeld & - \\
\hline Openbare orde- en Veiligheidsberoepen & - & erg hoog & - \\
\hline \multicolumn{4}{|l|}{ Opleiding } \\
\hline Basisonderwijs & - & gemiddeld & sterk stijgend \\
\hline VMBO Theorie & - & gemiddeld & sterk dalend \\
\hline VMBO Landbouw en techniek & - & laag & sterk dalend \\
\hline VMBO Economie & - & hoog & sterk stijgend \\
\hline VMBO Verzorging & - & erg laag & - \\
\hline HAVO/ VWO & - & erg hoog & sterk dalend \\
\hline MBO Landbouw en techniek & 81 & hoog & dalend \\
\hline MBO Economie & 89 & hoog & sterk dalend \\
\hline MBO Dienstverlening en gezondheidszorg & - & gemiddeld & sterk stijgend \\
\hline HO Landbouw en techniek & 88 & hoog & sterk dalend \\
\hline HO Economie & 96 & erg hoog & sterk stijgend \\
\hline HO Onderwijs en sociaal cultureel & - & erg hoog & - \\
\hline HO (Para)medisch & - & erg hoog & - \\
\hline
\end{tabular}

Bron: EBB (CBS) 
Ontwikkelingen in de structuur van de werkgelegenheid

Tabel 3.9

Uitstroomrisico, gemiddeld jaarlijks percentage, 1994-1998

$\%$

typering

Beroep

Technische en industrieberoepen

Transportberoepen

Economisch-administratieve beroepen

Verzorgende en dienstverlenende beroepen

$0,0 \quad-$

5,3 gemiddeld

Opleiding

Basisonderwijs

VMBO overig

$\mathrm{MBO}$

$11,1 \quad$ erg hoog

HBO

0,0

WO

gemiddeld

gemiddeld

Bron: SEP (CBS)

\section{Scholingsinspanningen}

Tabel 3.10

Deelname aan bedrijfsopleidingen, 2000 (momentopname)

\begin{tabular}{|c|c|c|c|}
\hline & $\%$ & typering & trend \\
\hline \multicolumn{4}{|l|}{ Beroep } \\
\hline Pedagogische beroepen & - & erg hoog & - \\
\hline Culturele beroepen & - & erg laag & - \\
\hline Technische en Industrieberoepen & 11 & erg hoog & constant \\
\hline Transportberoepen & - & erg hoog & sterk stijgend \\
\hline Medische en Paramedische beroepen & - & erg laag & - \\
\hline Economisch-administratieve beroepen & - & erg laag & stijgend \\
\hline Informaticaberoepen & - & erg hoog & - \\
\hline Sociaal-culturele beroepen & - & erg laag & - \\
\hline Verzorgende en Dienstverlenende beroepen & - & erg laag & - \\
\hline Openbare orde- en Veiligheidsberoepen & - & erg hoog & - \\
\hline \multicolumn{4}{|l|}{ Opleiding } \\
\hline Basisonderwijs & - & erg laag & sterk dalend \\
\hline VMBO Theorie & - & gemiddeld & sterk dalend \\
\hline VMBO Landbouw en techniek & - & hoog & sterk dalend \\
\hline VMBO Economie & - & erg hoog & sterk dalend \\
\hline VMBO Verzorging & - & erg laag & - \\
\hline HAVO/ VWO & - & erg hoog & sterk stijgend \\
\hline MBO Landbouw en techniek & - & erg hoog & stijgend \\
\hline MBO Economie & - & gemiddeld & constant \\
\hline MBO Dienstverlening en gezondheidszorg & - & erg laag & sterk dalend \\
\hline HO Landbouw en techniek & - & hoog & constant \\
\hline HO Economie & - & erg hoog & - \\
\hline HO Onderwijs en sociaal cultureel & - & erg laag & - \\
\hline HO (Para)medisch & - & erg laag & - \\
\hline
\end{tabular}

Bron: EBB (CBS) 


\section{Doelgroepen voor scholingsbeleid}

Tabel 3.11

Risicogroepen binnen de sector per risicofactor

Lichamelijke belasting

Beroep

Opleiding

VMBO landbouw en techniek

VMBO theorie (MAVO)

Psychische belasting

Beroep

Opleiding

Basisonderwijs

Informatisering

Beroep

Economisch- administratieve beroepen

Opleiding

Ontwikkelingen in de structuur van de werkgelegenheid

Beroep

Opleiding

Bron: ROA 

4. Metaal en elektrotechniek 

Tabel 4.1

Kernindicatoren

\section{Arbeidsomstandigheden}

Belastende arbeidsomstandigheden

$\%$

45

Lawaai

Trilling

Kracht zetten

Beeldschermwerk

Tijdsdruk

Verzuim vanwege lichamelijke belasting, percentage 1999

Verzuim vanwege de hoge werkdruk, percentage 1999

\section{Technologische en organisatorische ontwikkelingen}

Organisatorische ontwikkelingen

$1992-1994^{*}$

1994-1996*

$1996-1998$

$1992-1998$

Kleine veranderingen

Intensieve veranderingen

Veranderingen in positie

Interne reorganisaties

Technologische ontwikkelingen

18
17

17

14
17

9

$9 \quad 10$

10
9

22

13

$\begin{array}{lllll}1997 & 1998 & 1999 & 2000 & 2001\end{array}$

12

typering

erg hoog

erg hoog

gemiddeld

gemiddeld

laag

erg hoog

erg laag

FTE's ICT-personeel

$\begin{array}{lllll}0,66 & 0,66 & 0,65 & 0,70 & 0,76\end{array}$

$\begin{array}{rrrrr}0,66 & 0,66 & 0,65 & 0,70 & 0,76 \\ 92800 & 149500 & 160100 & 168800 & 172100\end{array}$

Reële automatiseringskosten (euro)

49500

26

$28 \quad 29$

\begin{tabular}{lllll}
21 & 24 & 26 & 28 & 29 \\
\hline
\end{tabular}

Aantal PC's in netwerk**

Aantal internet-PC's ${ }^{* *}$

(verandering 1998-2001)

-

$\begin{array}{lrrrrrr} & 1994 & 1995 & 1996 & 1997 & 1998 & 1999 \\ \text { Reële R\&D uitgaven } & 1301 & 1425 & 1445 & 1564 & 1510 & 1742\end{array}$

999 1994-1999*

6

Ontwikkelingen in de structuur van de werkgelegenheid

Uitstroomrisico, 1994-1998*

4,7

Verwachte uitbreidingsvraag, 2001-2006*

Flexibele arbeid, percentage 2000

7

trend

constant

typering hoog

Deelname aan bedrijfsopleidingen, percentage 2000 (momentopname)

Cursusparticipatie, percentage 1998-2000

Bron: K\&E, POLS, Automatiseringsstatistieken (allen CBS), Arbeidsaanbod- en arbeidsvraagpanel (beiden OSA), POA (ROA)

* Gemiddelde jaarlijkse percentages

** Aantal per bedrijf 


\section{Risicoprofiel}

Figuur 4.1

Sectoraal risicoprofiel

\section{Metaal- en elektrotechniek}

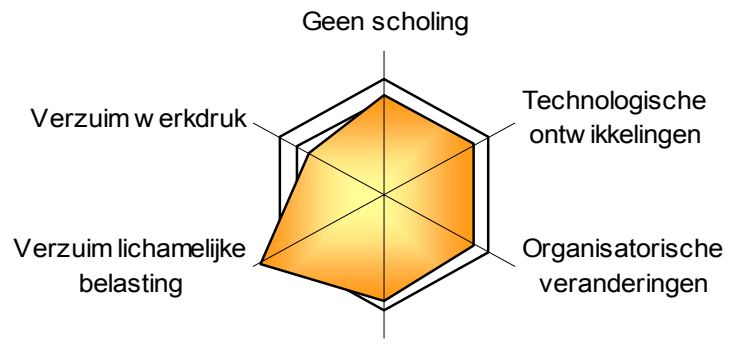

Uitstroomrisico

\section{Arbeidsomstandigheden}

Tabel 4.2

Percentage werkenden dat wordt geconfronteerd met lawaai tijdens het werk, 2000

\begin{tabular}{|c|c|c|c|}
\hline & $\%$ & typering & trend \\
\hline \multicolumn{4}{|l|}{ Bedrijfsgrootte } \\
\hline 5 tot 10 & 45 & erg hoog & sterk dalend \\
\hline 10 tot 20 & 50 & erg hoog & stijgend \\
\hline 20 tot 100 & 43 & erg hoog & constant \\
\hline 500 of meer & - & erg hoog & - \\
\hline \multicolumn{4}{|l|}{ Beroep } \\
\hline Pedagogische beroepen & - & erg hoog & - \\
\hline Culturele beroepen & - & erg hoog & - \\
\hline Technische en Industrieberoepen & 59 & erg hoog & constant \\
\hline Transportberoepen & 47 & erg hoog & sterk stijgend \\
\hline Medische en Paramedische beroepen & - & erg hoog & sterk stijgend \\
\hline Economisch-administratieve beroepen & 20 & gemiddeld & sterk stijgend \\
\hline Informaticaberoepen & - & erg hoog & sterk stijgend \\
\hline Sociaal-culturele beroepen & - & erg laag & - \\
\hline Verzorgende en Dienstverlenende beroepen & - & erg laag & - \\
\hline Openbare orde- en Veiligheidsberoepen & - & erg laag & - \\
\hline \multicolumn{4}{|l|}{ Opleiding } \\
\hline Basisonderwijs & 62 & erg hoog & stijgend \\
\hline VMBO Theorie & 37 & erg hoog & dalend \\
\hline VMBO Landbouw en techniek & 57 & erg hoog & dalend \\
\hline VMBO Economie & - & erg hoog & sterk dalend \\
\hline VMBO Verzorging & - & gemiddeld & sterk dalend \\
\hline HAVO/ VWO & - & hoog & sterk stijgend \\
\hline MBO Landbouw en techniek & 54 & erg hoog & stijgend \\
\hline MBO Economie & 21 & gemiddeld & sterk dalend \\
\hline MBO Dienstverlening en gezondheidszorg & - & erg hoog & sterk dalend \\
\hline HO Landbouw en techniek & 13 & laag & constant \\
\hline HO Economie & - & gemiddeld & sterk stijgend \\
\hline HO Onderwijs en sociaal cultureel & - & erg hoog & sterk stijgend \\
\hline $\mathrm{HO}$ (Para)medisch & - & - & - \\
\hline
\end{tabular}

Bron: EBB (CBS), bewerking ROA 
Tabel 4.3

Percentage werkenden dat gebruik maakt van gereedschap of apparaten die trilling veroorzaken, 2000

\begin{tabular}{|c|c|c|c|}
\hline & $\%$ & typering & trend \\
\hline \multicolumn{4}{|l|}{ Bedrijfsgrootte } \\
\hline 5 tot 10 & 58 & erg hoog & constant \\
\hline 10 tot 20 & 36 & erg hoog & constant \\
\hline 20 tot 100 & 27 & erg hoog & stijgend \\
\hline 500 of meer & - & erg hoog & - \\
\hline \multicolumn{4}{|l|}{ Beroep } \\
\hline Pedagogische beroepen & - & erg hoog & - \\
\hline Culturele beroepen & - & erg hoog & - $\quad$ \\
\hline Technische en Industrieberoepen & 45 & erg hoog & constant \\
\hline Transportberoepen & - & erg hoog & sterk stijgend \\
\hline Medische en Paramedische beroepen & - & erg hoog & - \\
\hline Economisch-administratieve beroepen & 7 & gemiddeld & sterk stijgend \\
\hline Informaticaberoepen & - & gemiddeld & - \\
\hline Sociaal-culturele beroepen & - & laag & - \\
\hline Verzorgende en Dienstverlenende beroepen & - & laag & - \\
\hline Openbare orde- en Veiligheidsberoepen & - & laag & - \\
\hline \multicolumn{4}{|l|}{ Opleiding } \\
\hline Basisonderwijs & 28 & erg hoog & sterk dalend \\
\hline VMBO Theorie & - & gemiddeld & sterk dalend \\
\hline VMBO Landbouw en techniek & 53 & erg hoog & stijgend \\
\hline VMBO Economie & - & erg hoog & sterk dalend \\
\hline VMBO Verzorging & - & erg hoog & sterk stijgend \\
\hline HAVO/ VWO & - & hoog & - \\
\hline MBO Landbouw en techniek & 38 & erg hoog & constant \\
\hline MBO Economie & - & gemiddeld & dalend \\
\hline MBO Dienstverlening en gezondheidszorg & - & erg hoog & sterk dalend \\
\hline HO Landbouw en techniek & - & gemiddeld & sterk stijgend \\
\hline HO Economie & - & laag & - \\
\hline HO Onderwijs en sociaal cultureel & - & gemiddeld & - \\
\hline
\end{tabular}

Bron: EBB (CBS) 
Tabel 4.4

Percentage werkenden dat kracht moet zetten tijdens het werk, 2000

\begin{tabular}{|c|c|c|c|}
\hline & $\%$ & typering & trend \\
\hline \multicolumn{4}{|l|}{ Bedrijfsgrootte } \\
\hline 5 tot 10 & 61 & erg hoog & sterk dalend \\
\hline 10 tot 20 & 49 & hoog & stijgend \\
\hline 20 tot 100 & 37 & gemiddeld & stijgend \\
\hline 500 of meer & - & hoog & - \\
\hline \multicolumn{4}{|l|}{ Beroep } \\
\hline Pedagogische beroepen & - & gemiddeld & - \\
\hline Culturele beroepen & - & gemiddeld & - \\
\hline Technische en Industrieberoepen & 56 & hoog & constant \\
\hline Transportberoepen & 51 & hoog & dalend \\
\hline Medische en Paramedische beroepen & - & gemiddeld & sterk stijgend \\
\hline Economisch-administratieve beroepen & 17 & laag & sterk stijgend \\
\hline Informaticaberoepen & - & erg laag & - \\
\hline Sociaal-culturele beroepen & - & erg laag & - \\
\hline Verzorgende en Dienstverlenende beroepen & - & erg laag & - \\
\hline Openbare orde- en Veiligheidsberoepen & - & laag & - \\
\hline \multicolumn{4}{|l|}{ Opleiding } \\
\hline Basisonderwijs & 66 & erg hoog & sterk stijgend \\
\hline VMBO Theorie & 46 & gemiddeld & stijgend \\
\hline VMBO Landbouw en techniek & 67 & erg hoog & stijgend \\
\hline VMBO Economie & - & hoog & sterk dalend \\
\hline VMBO Verzorging & - & hoog & dalend \\
\hline HAVO/ VWO & - & gemiddeld & stijgend \\
\hline MBO Landbouw en techniek & 45 & gemiddeld & constant \\
\hline MBO Economie & - & laag & sterk dalend \\
\hline MBO Dienstverlening en gezondheidszorg & - & gemiddeld & sterk dalend \\
\hline HO Landbouw en techniek & - & erg laag & sterk stijgend \\
\hline HO Economie & - & erg laag & - \\
\hline HO Onderwijs en sociaal cultureel & - & laag & sterk stijgend \\
\hline
\end{tabular}

Bron: EBB (CBS) 
Tabel 4.5

Percentage werkenden dat onder hoge tijdsdruk werkt, 2000

\begin{tabular}{|c|c|c|c|}
\hline & $\%$ & typering & trend \\
\hline \multicolumn{4}{|l|}{ Bedrijfsgrootte } \\
\hline 5 tot 10 & 42 & erg laag & sterk dalend \\
\hline 10 tot 20 & 56 & gemiddeld & constant \\
\hline 20 tot 100 & 62 & gemiddeld & dalend \\
\hline 100 tot 500 & - & - & sterk dalend \\
\hline 500 of meer & 53 & laag & - \\
\hline \multicolumn{4}{|l|}{ Beroep } \\
\hline Pedagogische beroepen & - & erg hoog & - \\
\hline Culturele beroepen & - & erg hoog & sterk dalend \\
\hline Agrarische beroepen & - & hoog & - \\
\hline Technische en Industrieberoepen & 58 & gemiddeld & dalend \\
\hline Transportberoepen & 52 & laag & sterk stijgend \\
\hline Medische en Paramedische beroepen & - & gemiddeld & sterk dalend \\
\hline Economisch-administratieve beroepen & 60 & gemiddeld & dalend \\
\hline Informaticaberoepen & 64 & gemiddeld & constant \\
\hline Sociaal-culturele beroepen & - & erg hoog & sterk stijgend \\
\hline Verzorgende en Dienstverlenende beroepen & - & laag & stijgend \\
\hline Openbare orde- en Veiligheidsberoepen & - & laag & sterk stijgend \\
\hline \multicolumn{4}{|l|}{ Opleiding } \\
\hline Basisonderwijs & 50 & laag & constant \\
\hline VMBO Theorie & 61 & gemiddeld & stijgend \\
\hline VMBO Landbouw en techniek & 50 & laag & dalend \\
\hline VMBO Economie & - & laag & sterk dalend \\
\hline VMBO Verzorging & - & erg laag & sterk dalend \\
\hline HAVO/ VWO & 58 & gemiddeld & sterk stijgend \\
\hline MBO Landbouw en techniek & 61 & gemiddeld & constant \\
\hline MBO Economie & 54 & laag & dalend \\
\hline MBO Dienstverlening en gezondheidszorg & & erg laag & sterk dalend \\
\hline HO Landbouw en techniek & 79 & erg hoog & constant \\
\hline HO Economie & 73 & erg hoog & constant \\
\hline HO Onderwijs en sociaal cultureel & - & erg hoog & sterk dalend \\
\hline $\mathrm{HO}$ (Para)medisch & - & erg laag & - \\
\hline
\end{tabular}

Bron: EBB (CBS) 
Tabel 4.6

Percentage werkenden dat als gevolg van klachten door lichamelijke belasting het werk heeft verzuimd, 1999

typering

Beroep

Culturele beroepen

Technische en Industrieberoepen

Transportberoepen

Medische en Paramedische beroepen

Economisch-administratieve beroepen

Informaticaberoepen

erg laag

erg hoog

erg hoog

erg laag

gemiddeld

erg laag

Opleiding

Basisonderwijs

VMBO Theorie

VMBO Landbouw en techniek

VMBO Economie

VMBO Verzorging

HAVO/ VWO

MBO Landbouw en techniek

MBO Economie

MBO Dienstverlening en gezondheidszorg

HO Landbouw en techniek

HO Economie

$\mathrm{HO}$ Onderwijs en sociaal cultureel

$\mathrm{HO}$ (Para)medisch

Bron: POLS (CBS)

Tabel 4.7

Percentage werkenden dat als gevolg van problemen met de werkdruk het werk heeft verzuimd, 1999

typering

Beroep

Culturele beroepen

Technische en Industrieberoepen

Transportberoepen

Medische en Paramedische beroepen

Economisch-administratieve beroepen

Informaticaberoepen

erg hoog

erg hoog

erg hoog

erg laag

erg hoog

erg hoog

erg hoog

laag

erg laag

erg laag

erg laag

erg laag

erg hoog

Opleiding

Basisonderwijs

VMBO Theorie

VMBO Landbouw en techniek

VMBO Economie

VMBO Verzorging

HAVO/ VWO

MBO Landbouw en techniek

MBO Economie

MBO Dienstverlening en gezondheidszorg

HO Landbouw en techniek

HO Economie

HO Onderwijs en sociaal cultureel

erg laag

laag

erg laag

erg laag

erg laag

erg laag

erg laag

erg laag

erg laag

erg laag

erg hoog

erg hoog

gemiddeld

erg laag

erg laag

erg laag

erg laag

erg laag

Bron: POLS (CBS) 
Technologische en organisatorische ontwikkelingen

Tabel 4.8

Informatisering, 2000

\begin{tabular}{|c|c|c|c|}
\hline & $\%$ & typering & trend \\
\hline \multicolumn{4}{|l|}{ Bedrijfsgrootte } \\
\hline 5 tot 10 & 29 & laag & stijgend \\
\hline 10 tot 20 & 51 & gemiddeld & sterk stijgend \\
\hline 20 tot 100 & 65 & gemiddeld & constant \\
\hline 500 of meer & - & laag & - \\
\hline \multicolumn{4}{|l|}{ Beroep } \\
\hline Pedagogische beroepen & - & gemiddeld & - \\
\hline Culturele beroepen & - & erg hoog & - \\
\hline Technische en Industrieberoepen & 45 & gemiddeld & stijgend \\
\hline Transportberoepen & 37 & laag & sterk stijgend \\
\hline Medische en Paramedische beroepen & - & erg laag & sterk dalend \\
\hline Economisch-administratieve beroepen & 89 & hoog & constant \\
\hline Informaticaberoepen & 97 & erg hoog & stijgend \\
\hline Sociaal-culturele beroepen & - & erg hoog & sterk stijgend \\
\hline Verzorgende en Dienstverlenende beroepen & - & hoog & sterk stijgend \\
\hline Openbare orde- en Veiligheidsberoepen & - & gemiddeld & - \\
\hline \multicolumn{4}{|l|}{ Opleiding } \\
\hline Basisonderwijs & 26 & laag & sterk stijgend \\
\hline VMBO Theorie & 53 & gemiddeld & constant \\
\hline VMBO Landbouw en techniek & 33 & laag & sterk stijgend \\
\hline VMBO Economie & - & erg laag & sterk dalend \\
\hline VMBO Verzorging & - & erg laag & - \\
\hline HAVO/ VWO & 71 & hoog & sterk stijgend \\
\hline MBO Landbouw en techniek & 60 & gemiddeld & sterk stijgend \\
\hline MBO Economie & 85 & hoog & constant \\
\hline MBO Dienstverlening en gezondheidszorg & - & laag & - \\
\hline HO Landbouw en techniek & 98 & erg hoog & dalend \\
\hline HO Economie & 97 & erg hoog & dalend \\
\hline HO Onderwijs en sociaal cultureel & & gemiddeld & sterk dalend \\
\hline
\end{tabular}

Bron: EBB (CBS) 
Ontwikkelingen in de structuur van de werkgelegenheid

Tabel 4.9

Uitstroomrisico, gemiddeld jaarlijks percentage, 1994-1998

$\%$

typering

Beroep

Technische en industrieberoepen

Transportberoepen

Economisch-administratieve beroepen

Informaticaberoepen

Verzorgende en dienstverlenende beroepen

gemiddeld

$\begin{aligned} 11,1 & \text { erg hoog } \\ 7,5 & \text { gemiddeld }\end{aligned}$

erg hoog

Opleiding

Basisonderwijs

VMBO theorie

VMBO overig

14,9 erg hoog

HAVO/VWO

12,5

erg hoog

gemiddeld

MBO

6,3
11,1

hoog

$\mathrm{HBO}$

gemiddeld

WO

4,9

gemiddeld

Bron: SEP (CBS)

\section{Scholingsinspanningen}

Tabel 4.10

Deelname aan bedrijfsopleidingen, 2000 (momentopname)

\begin{tabular}{|c|c|c|c|}
\hline & $\%$ & typering & trend \\
\hline \multicolumn{4}{|l|}{ Beroep } \\
\hline Pedagogische beroepen & - & erg hoog & - \\
\hline Culturele beroepen & - & erg laag & - \\
\hline Agrarische beroepen & - & erg laag & - \\
\hline Technische en Industrieberoepen & 8 & hoog & stijgend \\
\hline Transportberoepen & - & erg laag & dalend \\
\hline Medische en Paramedische beroepen & - & erg hoog & sterk dalend \\
\hline Economisch-administratieve beroepen & - & laag & constant \\
\hline Informaticaberoepen & - & erg hoog & sterk stijgend \\
\hline Sociaal-culturele beroepen & - & erg laag & - \\
\hline Verzorgende en Dienstverlenende beroepen & - & gemiddeld & - \\
\hline Openbare orde- en Veiligheidsberoepen & - & erg hoog & sterk stijgend \\
\hline \multicolumn{4}{|l|}{ Opleiding } \\
\hline Basisonderwijs & - & erg laag & constant \\
\hline VMBO Theorie & - & erg laag & sterk dalend \\
\hline VMBO Landbouw en techniek & - & gemiddeld & stijgend \\
\hline VMBO Economie & - & erg laag & - \\
\hline VMBO Verzorging & - & gemiddeld & - \\
\hline HAVO/VWO & - & erg laag & sterk dalend \\
\hline MBO Landbouw en techniek & 10 & erg hoog & sterk stijgend \\
\hline MBO Economie & - & laag & sterk dalend \\
\hline MBO Dienstverlening en gezondheidszorg & - & erg laag & sterk dalend \\
\hline HO Landbouw en techniek & - & erg hoog & sterk stijgend \\
\hline HO Economie & - & laag & sterk stijgend \\
\hline HO Onderwijs en sociaal cultureel & - & erg hoog & sterk stijgend \\
\hline HO (Para)medisch & - & erg laag & - \\
\hline
\end{tabular}

Bron: EBB (CBS) 


\section{Doelgroepen voor scholingsbeleid}

Tabel 4.11

Risicogroepen binnen de sector per risicofactor

Lichamelijke belasting

Beroep

Transportberoepen

Opleiding

Basisonderwijs

Psychische belasting

Beroep

Opleiding

Informatisering

Beroep

Opleiding

HAVO/ VWO

Ontwikkelingen in de structuur van de werkgelegenheid Beroep

Verzorgende en dienstverlenende beroepen

Opleiding

Basisonderwijs

Bron: ROA 

5. Overige industrie 

Tabel 5.1

Kernindicatoren

\section{Arbeidsomstandigheden}

Belastende arbeidsomstandigheden

Lawaai

Trilling

Kracht zetten

Beeldschermwerk

Tijdsdruk

$\begin{array}{rr}\% & \text { typering } \\ 38 & \text { erg hoog } \\ 25 & \text { hoog } \\ 42 & \text { gemiddeld } \\ 47 & \text { gemiddeld } \\ 54 & \text { laag } \\ & \\ 10 & \text { hoog } \\ 10 & \text { erg hoog }\end{array}$

Verzuim vanwege lichamelijke belasting, percentage 1999

Verzuim vanwege de hoge werkdruk, percentage 1999

erg hoog

\section{Technologische en organisatorische ontwikkelingen}

\begin{tabular}{|c|c|c|c|c|c|c|}
\hline Organisatorische ontwikkelingen & 1992-1994* & \multicolumn{2}{|c|}{$1994-1996 *$} & \multicolumn{2}{|c|}{$1996-1998^{*}$} & $1992-1998^{*}$ \\
\hline Kleine veranderingen & 17 & & 8 & & 10 & 6 \\
\hline Intensieve veranderingen & 12 & & 9 & & 14 & 6 \\
\hline Veranderingen in positie & 8 & & 41 & & 5 & 9 \\
\hline Interne reorganisaties & 8 & & 18 & & 18 & 7 \\
\hline Technologische ontwikkelingen & 1997 & 1998 & 1999 & 2000 & 2001 & $1997-2001^{*}$ \\
\hline FTE's ICT-personeel & 0,48 & 0,48 & 0,49 & 0,53 & 0,57 & \\
\hline Reële automatiseringskosten (euro) & 61500 & 67900 & 66300 & 72400 & 74800 & \\
\hline Aantal PC's** & 16 & 15 & 17 & 18 & 19 & \\
\hline Aantal PC's in netwerk ${ }^{* *}$ & 13 & 14 & 15 & 16 & 17 & \\
\hline Aantal internet-PC's** & - & 6 & 6 & 8 & 10 & 22 \\
\hline 1994 & 1995 & 1996 & 1997 & 1998 & 1999 & $1994-1998$ \\
\hline Reële R\&D uitgaven & 54 & 65 & 65 & 57 & 74 & \\
\hline
\end{tabular}

Ontwikkelingen in de structuur van de werkgelegenheid

Uitstroomrisico, 1994-1998*

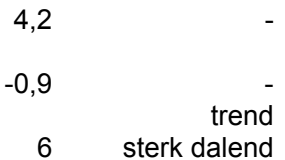

Flexibele arbeid, percentage 2000

typering

\section{Scholingsdeelname}

Deelname aan bedrijfsopleidingen, percentage 2000 (momentopname)

Cursusparticipatie, percentage 1998-2000

Bron: K\&E, POLS, Automatiseringsstatistieken (allen CBS), Arbeidsaanbod- en arbeidsvraagpanel (beiden OSA), POA (ROA)

* Gemiddelde jaarlijkse percentages

** Aantal per bedrijf 


\section{Risicoprofiel}

Figuur 5.1

Sectoraal risicoprofiel

\section{Overige industrie}

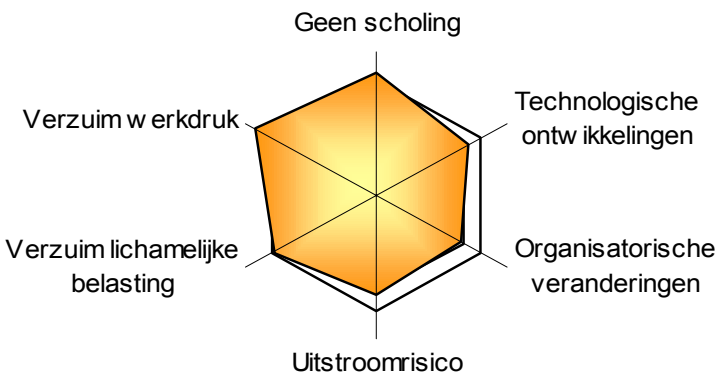

\section{Arbeidsomstandigheden}

Tabel 5.2

Percentage werkenden dat wordt geconfronteerd met lawaai tijdens het werk, 2000

\begin{tabular}{|c|c|c|c|}
\hline & $\%$ & typering & trend \\
\hline \multicolumn{4}{|l|}{ Bedrijfsgrootte } \\
\hline 5 tot 10 & 33 & hoog & constant \\
\hline 10 tot 20 & 43 & erg hoog & stijgend \\
\hline 20 tot 100 & 36 & erg hoog & constant \\
\hline 500 of meer & - & erg hoog & - \\
\hline \multicolumn{4}{|l|}{ Beroep } \\
\hline Pedagogische beroepen & - & erg laag & - \\
\hline Culturele beroepen & - & gemiddeld & sterk stijgend \\
\hline Agrarische beroepen & - & gemiddeld & constant \\
\hline Technische en Industrieberoepen & 60 & erg hoog & constant \\
\hline Transportberoepen & 41 & erg hoog & sterk stijgend \\
\hline Economisch-administratieve beroepen & 16 & gemiddeld & constant \\
\hline Informaticaberoepen & - & erg hoog & sterk stijgend \\
\hline Sociaal-culturele beroepen & - & erg laag & - \\
\hline Verzorgende en Dienstverlenende beroepen & - & laag & sterk dalend \\
\hline Openbare orde- en Veiligheidsberoepen & - & erg laag & - \\
\hline \multicolumn{4}{|l|}{ Opleiding } \\
\hline Basisonderwijs & 39 & erg hoog & stijgend \\
\hline VMBO Theorie & 47 & erg hoog & sterk stijgend \\
\hline VMBO Landbouw en techniek & 49 & erg hoog & constant \\
\hline VMBO Economie & - & erg hoog & sterk dalend \\
\hline VMBO Verzorging & - & hoog & stijgend \\
\hline HAVO/ VWO & - & laag & sterk dalend \\
\hline MBO Landbouw en techniek & 48 & erg hoog & dalend \\
\hline MBO Economie & 24 & gemiddeld & dalend \\
\hline MBO Dienstverlening en gezondheidszorg & - & hoog & sterk dalend \\
\hline HO Landbouw en techniek & - & gemiddeld & sterk stijgend \\
\hline HO Economie & - & laag & sterk stijgend \\
\hline HO Onderwijs en sociaal cultureel & - & laag & sterk stijgend \\
\hline
\end{tabular}

Bron: EBB (CBS), bewerking ROA 
Tabel 5.3

Percentage werkenden dat gebruik maakt van gereedschap of apparaten die trilling veroorzaken, 2000

\begin{tabular}{|c|c|c|c|}
\hline & $\%$ & typering & trend \\
\hline \multicolumn{4}{|l|}{ Bedrijfsgrootte } \\
\hline 5 tot 10 & 29 & erg hoog & stijgend \\
\hline 10 tot 20 & 29 & erg hoog & stijgend \\
\hline 20 tot 100 & 21 & hoog & constant \\
\hline 500 of meer & - & erg hoog & - \\
\hline \multicolumn{4}{|l|}{ Beroep } \\
\hline Pedagogische beroepen & - & laag & - \\
\hline Culturele beroepen & - & laag & - \\
\hline Agrarische beroepen & 29 & erg hoog & constant \\
\hline Technische en Industrieberoepen & 41 & erg hoog & constant \\
\hline Transportberoepen & - & gemiddeld & dalend \\
\hline Economisch-administratieve beroepen & 8 & gemiddeld & sterk stijgend \\
\hline Informaticaberoepen & - & gemiddeld & - \\
\hline Sociaal-culturele beroepen & - & laag & - \\
\hline Verzorgende en Dienstverlenende beroepen & - & gemiddeld & sterk stijgend \\
\hline Openbare orde- en Veiligheidsberoepen & - & erg hoog & - \\
\hline \multicolumn{4}{|l|}{ Opleiding } \\
\hline Basisonderwijs & 28 & erg hoog & stijgend \\
\hline VMBO Theorie & - & gemiddeld & dalend \\
\hline VMBO Landbouw en techniek & 41 & erg hoog & stijgend \\
\hline VMBO Economie & - & erg hoog & stijgend \\
\hline VMBO Verzorging & - & hoog & sterk stijgend \\
\hline HAVO/ VWO & - & gemiddeld & sterk stijgend \\
\hline MBO Landbouw en techniek & 31 & erg hoog & dalend \\
\hline MBO Economie & - & gemiddeld & stijgend \\
\hline MBO Dienstverlening en gezondheidszorg & - & hoog & stijgend \\
\hline HO Landbouw en techniek & - & gemiddeld & sterk stijgend \\
\hline HO Economie & - & hoog & - \\
\hline HO Onderwijs en sociaal cultureel & - & laag & - \\
\hline
\end{tabular}

Bron: EBB (CBS) 
Tabel 5.4

Percentage werkenden dat kracht moet zetten tijdens het werk, 2000

\begin{tabular}{|c|c|c|c|}
\hline & $\%$ & typering & trend \\
\hline \multicolumn{4}{|l|}{ Bedrijfsgrootte } \\
\hline 5 tot 10 & 43 & gemiddeld & stijgend \\
\hline 10 tot 20 & 49 & hoog & stijgend \\
\hline 20 tot 100 & 37 & gemiddeld & stijgend \\
\hline 500 of meer & - & erg hoog & - \\
\hline \multicolumn{4}{|l|}{ Beroep } \\
\hline Pedagogische beroepen & - & erg laag & - \\
\hline Culturele beroepen & - & erg laag & sterk stijgend \\
\hline Agrarische beroepen & 48 & hoog & dalend \\
\hline Technische en Industrieberoepen & 58 & hoog & constant \\
\hline Transportberoepen & 50 & hoog & stijgend \\
\hline Economisch-administratieve beroepen & 22 & laag & sterk stijgend \\
\hline Informaticaberoepen & - & gemiddeld & sterk stijgend \\
\hline Sociaal-culturele beroepen & - & erg laag & - \\
\hline Verzorgende en Dienstverlenende beroepen & - & gemiddeld & sterk stijgend \\
\hline Openbare orde- en Veiligheidsberoepen & - & erg hoog & - \\
\hline \multicolumn{4}{|l|}{ Opleiding } \\
\hline Basisonderwijs & 48 & hoog & constant \\
\hline VMBO Theorie & 42 & gemiddeld & stijgend \\
\hline VMBO Landbouw en techniek & 62 & erg hoog & stijgend \\
\hline VMBO Economie & - & erg hoog & dalend \\
\hline VMBO Verzorging & 51 & hoog & sterk stijgend \\
\hline HAVO/ VWO & - & laag & sterk stijgend \\
\hline MBO Landbouw en techniek & 46 & gemiddeld & dalend \\
\hline MBO Economie & 21 & laag & constant \\
\hline MBO Dienstverlening en gezondheidszorg & - & erg hoog & sterk stijgend \\
\hline HO Landbouw en techniek & - & laag & sterk stijgend \\
\hline HO Economie & - & erg laag & - \\
\hline HO Onderwijs en sociaal cultureel & - & erg laag & sterk stijgend \\
\hline
\end{tabular}

Bron: EBB (CBS) 
Tabel 5.5

Percentage werkenden dat onder hoge tijdsdruk werkt, 2000

$\% \quad$ typering trend

Bedrijfsgrootte

5 tot 10

10 tot 20

20 tot 100

500 of meer

$\begin{array}{cll}54 & \text { laag } & \text { stijgend } \\ 58 & \text { gemiddeld } & \text { constant } \\ 53 & \text { laag } & \text { dalend } \\ - & \text { erg laag } & -\end{array}$

Beroep

Pedagogische beroepen

Culturele beroepen

Agrarische beroepen

Technische en Industrieberoepen

Transportberoepen

Medische en Paramedische beroepen

Economisch-administratieve beroepen

Informaticaberoepen

Sociaal-culturele beroepen

Verzorgende en Dienstverlenende beroepen

Openbare orde- en Veiligheidsberoepen

Opleiding

Basisonderwijs

VMBO Theorie

VMBO Landbouw en techniek

VMBO Economie

VMBO Verzorging

HAVO/ VWO

MBO Landbouw en techniek

MBO Economie

MBO Dienstverlening en gezondheidszorg

HO Landbouw en techniek

HO Economie

$\mathrm{HO}$ Onderwijs en sociaal cultureel

HO (Para)medisch

$\begin{array}{cll}- & \text { erg hoog } & \text { sterk stijgend } \\ 77 & \text { erg hoog } & \text { constant } \\ - & \text { erg laag } & \text { dalend } \\ 58 & \text { gemiddeld } & \text { dalend } \\ 46 & \text { erg laag } & \text { constant } \\ - & \text { erg hoog } & - \\ 53 & \text { laag } & \text { constant } \\ - & \text { erg hoog } & \text { stijgend } \\ - & \text { gemiddeld } & \text { sterk stijgend } \\ - & \text { erg laag } & \text { sterk stijgend } \\ - & \text { erg laag } & - \\ & & \\ 36 & \text { erg laag } & \text { constant } \\ 50 & \text { laag } & \text { sterk dalend } \\ 46 & \text { erg laag } & \text { dalend } \\ - & \text { erg laag } & \text { sterk dalend } \\ - & \text { erg laag } & \text { sterk stijgend } \\ 64 & \text { gemiddeld } & \text { sterk stijgend } \\ 65 & \text { gemiddeld } & \text { dalend } \\ 61 & \text { gemiddeld } & \text { dalend } \\ - & \text { gemiddeld } & \text { dalend } \\ 74 & \text { erg hoog } & \text { stijgend } \\ 72 & \text { hoog } & \text { constant } \\ 78 & \text { erg hoog } & \text { stijgend } \\ - & \text { erg hoog } & \text { sterk stijgend }\end{array}$

Bron: EBB (CBS) 
Tabel 5.6

Percentage werkenden dat als gevolg van klachten door lichamelijke belasting het werk heeft verzuimd, 1999

$\%$

typering

Beroep

Culturele beroepen

Agrarische beroepen

Technische en Industrieberoepen

Transportberoepen

Economisch-administratieve beroepen

Informaticaberoepen

Sociaal-culturele beroepen

Verzorgende en Dienstverlenende beroepen

Openbare orde- en Veiligheidsberoepen

hoog

6 gemiddeld

14 erg hoog

erg laag

gemiddeld

erg laag

erg laag

erg laag

erg laag

Opleiding

Basisonderwijs

VMBO Theorie

VMBO Landbouw en techniek

VMBO Economie

VMBO Verzorging

HAVO/ VWO

MBO Landbouw en techniek

MBO Economie

MBO Dienstverlening en gezondheidszorg

$\mathrm{HO}$ Landbouw en techniek

HO Economie

HO Onderwijs en sociaal cultureel

HO (Para)medisch

erg hoog

laag

erg hoog

erg hoog

erg laag

erg hoog

gemiddeld

erg laag

erg laag

erg laag

erg laag

erg laag

- $\quad$ erg hoog

Bron: POLS (CBS) 
Tabel 5.7

Percentage werkenden dat als gevolg van problemen met de werkdruk het werk heeft verzuimd, 1999

$\% \quad$ typering

Beroep

Culturele beroepen

Agrarische beroepen

Technische en Industrieberoepen

Transportberoepen

Economisch-administratieve beroepen

nformaticaberoepen

Sociaal-culturele beroepen

Verzorgende en Dienstverlenende beroepen

Openbare orde- en Veiligheidsberoepen

erg laag

6 gemiddeld

hoog

erg hoog

erg hoog

erg laag

erg hoog

- $\quad$ erg laag

Opleiding

Basisonderwijs

VMBO Theorie

VMBO Landbouw en techniek

erg laag

VMBO Economie

VMBO Verzorging

HAVO/ VWO

MBO Landbouw en techniek

erg hoog

MBO Economie

MBO Dienstverlening en gezondheidszorg

erg hoog

erg hoog

erg hoog

erg laag

erg hoog

gemiddeld

erg laag

HO Landbouw en techniek

erg hoog

HO Economie

$\mathrm{HO}$ Onderwijs en sociaal cultureel

erg laag

erg laag

erg laag

Bron: POLS (CBS) 
Technologische en organisatorische ontwikkelingen

Tabel 5.8

Informatisering, 2000

\begin{tabular}{|c|c|c|c|}
\hline & $\%$ & typering & trend \\
\hline \multicolumn{4}{|l|}{ Bedrijfsgrootte } \\
\hline 5 tot 10 & 41 & laag & stijgend \\
\hline 10 tot 20 & 47 & gemiddeld & stijgend \\
\hline 20 tot 100 & 50 & gemiddeld & constant \\
\hline 100 tot 500 & - & gemiddeld & - \\
\hline 500 of meer & - & erg laag & - \\
\hline \multicolumn{4}{|l|}{ Beroep } \\
\hline Pedagogische beroepen & 14 & erg laag & stijgend \\
\hline Culturele beroepen & 51 & gemiddeld & dalend \\
\hline Agrarische beroepen & 21 & erg laag & sterk dalend \\
\hline Technische en Industrieberoepen & - & erg laag & - \\
\hline Transportberoepen & - & erg laag & stijgend \\
\hline Medische en Paramedische beroepen & 75 & hoog & sterk stijgend \\
\hline Economisch-administratieve beroepen & 63 & gemiddeld & stijgend \\
\hline Informaticaberoepen & 77 & hoog & dalend \\
\hline Sociaal-culturele beroepen & - & laag & dalend \\
\hline Verzorgende en Dienstverlenende beroepen & 100 & erg hoog & sterk stijgend \\
\hline Openbare orde- en Veiligheidsberoepen & 94 & erg hoog & sterk dalend \\
\hline \multicolumn{4}{|l|}{ Opleiding } \\
\hline Basisonderwijs & 14 & erg laag & stijgend \\
\hline VMBO Theorie & 51 & gemiddeld & dalend \\
\hline VMBO Landbouw en techniek & 21 & erg laag & sterk dalend \\
\hline VMBO Verzorging & - & - & stijgend \\
\hline HAVO/ VWO & 75 & hoog & sterk stijgend \\
\hline MBO Landbouw en techniek & 63 & gemiddeld & stijgend \\
\hline MBO Economie & 77 & hoog & dalend \\
\hline MBO Dienstverlening en gezondheidszorg & - & laag & dalend \\
\hline HO Landbouw en techniek & 100 & erg hoog & sterk stijgend \\
\hline HO Economie & 94 & erg hoog & sterk dalend \\
\hline HO Onderwijs en sociaal cultureel & 89 & hoog & sterk stijgend \\
\hline
\end{tabular}

Bron: EBB (CBS) 
Ontwikkelingen in de structuur van de werkgelegenheid

Tabel 5.9

Uitstroomrisico, gemiddeld jaarlijks percentage, 1994-1998

$\%$

typering

Beroep

Culturele beroepen

Agrarische beroepen

Technische en industrieberoepen

Transportberoepen

0,0

Economisch-administratieve beroepen

$4,9 \quad$ gemiddeld

gemiddeld

gemiddeld

Informaticaberoepen

Sociaal-culturele beroepen

Verzorgende en dienstverlenende beroepen

hoog

Opleiding

Basisonderwijs $\quad 6,4 \quad$ gemiddeld

VMBO theorie $\quad 2,7$ gemiddeld

VMBO overig 4,9 gemiddeld

HAVO/VWO 6,3 gemiddeld

$\mathrm{MBO} \quad 3,6 \quad$ gemiddeld

HBO 2,4 laag

WO

Bron: SEP (CBS)

\section{Scholingsinspanningen}

Tabel 5.10

Deelname aan bedrijfsopleidingen, 2000 (momentopname)

\begin{tabular}{llll}
\hline & & & \\
& $\%$ & typering & trend \\
\hline Beroep & & & \\
Pedagogische beroepen & - & erg laag & - \\
Culturele beroepen & - & erg laag & - \\
Agrarische beroepen & - & erg laag & sterk stijgend \\
Technische en Industrieberoepen & 5 & erg laag & stijgend \\
Transportberoepen & - & erg laag & sterk dalend \\
Medische en Paramedische beroepen & - & erg laag & - \\
Economisch-administratieve beroepen & - & erg laag & stijgend \\
Informaticaberoepen & - & erg hoog & sterk dalend \\
Sociaal-culturele beroepen & - & laag & constant \\
Verzorgende en Dienstverlenende beroepen & - & erg laag & - \\
Openbare orde- en Veiligheidsberoepen & - & erg laag & - \\
Opleiding & & & \\
Basisonderwijs & - & erg laag & sterk stijgend \\
VMBO Theorie & - & gemiddeld & constant \\
VMBO Landbouw en techniek & - & erg laag & sterk dalend \\
VMBO Economie & - & erg laag & - \\
VMBO Verzorging & - & erg laag & - \\
HAVO/ VWO & - & laag & sterk stijgend \\
MBO Landbouw en techniek & - & laag & stijgend \\
MBO Economie & - & erg laag & constant \\
MBO Dienstverlening en gezondheidszorg & - & erg hoog & sterk stijgend \\
HO Landbouw en techniek & - & erg laag & sterk stijgend \\
HO Economie & - & erg laag & sterk dalend \\
HO Onderwijs en sociaal cultureel & erg laag & sterk stijgend \\
HO (Para)medisch & - & erg laag & - \\
\hline Bron: EBB (CBS) & - & & \\
\hline
\end{tabular}

Bron: EBB (CBS) 


\section{Doelgroepen voor scholingsbeleid}

Tabel 5.11

Risicogroepen binnen de sector per risicofactor

Lichamelijke belasting

Beroep

Opleiding

Psychische belasting

Beroep

Opleiding

Informatisering

Beroep

Opleiding

Ontwikkelingen in de structuur van de werkgelegenheid Beroep

Opleiding
Transportberoepen

Basisonderwijs

Transportberoepen

Economisch- administratieve beroepen

MBO dienstverlening en gezondheidszorg

HAVO/ VWO

Culturele beroepen

$\mathrm{HO}$ economie

$\mathrm{HO}$ landbouw en techniek

Verzorgende en dienstverlenende beroepen

Bron: ROA 
6. Energie 

Tabel 6.1

Kernindicatoren

\section{Arbeidsomstandigheden}

Belastende arbeidsomstandigheden

Lawaai

Trilling

Kracht zetten

Beeldschermwerk

Tijdsdruk

$\begin{array}{rr}\% & \text { typering } \\ 22 & \text { gemiddeld } \\ 22 & \text { hoog } \\ 28 & \text { gemiddeld } \\ 83 & \text { hoog } \\ 63 & \text { gemiddeld } \\ & \\ - & \text { erg laag } \\ - & \text { erg laag }\end{array}$

Verzuim vanwege lichamelijke belasting, percentage 1999

Verzuim vanwege de hoge werkdruk, percentage 1999

\section{Technologische en organisatorische ontwikkelingen}

\begin{tabular}{|c|c|c|c|c|c|c|}
\hline Organisatorische ontwikkelingen & 992-1994* & & $94-1996^{*}$ & & 996-1998* & $1992-1998^{*}$ \\
\hline Kleine veranderingen & 4 & & 6 & & 1 & 2 \\
\hline Intensieve veranderingen & 5 & & 2 & & 1 & 1 \\
\hline Veranderingen in positie & 19 & & 67 & & 44 & 22 \\
\hline Interne reorganisaties & 17 & & 60 & & 67 & 24 \\
\hline Technologische ontwikkelingen & 1997 & 1998 & 1999 & 2000 & 2001 & $1997-2001^{*}$ \\
\hline FTE's ICT-personeel & 5,23 & 4,42 & 4,43 & 4,64 & 4,68 & -3 \\
\hline Reële automatiseringskosten (euro) & 940700 & 945800 & 951700 & 1010200 & 1032200 & 2 \\
\hline Aantal PC's** & 147 & 141 & 135 & 139 & 139 & -1 \\
\hline Aantal PC's in netwerk ${ }^{* *}$ & 135 & 134 & 127 & 131 & 134 & 0 \\
\hline Aantal internet-PC's** & - & 58 & 61 & 74 & 82 & 12 \\
\hline 1994 & 1995 & 1996 & 1997 & 1998 & 1999 & 1994-1999* \\
\hline Reële R\&D uitgaven & 103 & 64 & 135 & 167 & 99 & \\
\hline
\end{tabular}

Ontwikkelingen in de structuur van de werkgelegenheid

Uitstroomrisico, 1994-1998*

Verwachte uitbreidingsvraag, 2001-2006*

Flexibele arbeid, percentage 2000

\section{Scholingsdeelname}

Deelname aan bedrijfsopleidingen, percentage 2000 (momentopname)

typering

Cursusparticipatie, percentage 1998-2000

Bron: K\&E, POLS, Automatiseringsstatistieken (allen CBS), Arbeidsaanbod- en arbeidsvraagpanel (beiden OSA), POA (ROA)

* Gemiddelde jaarlijkse percentages

** Aantal per bedrijf 


\section{Risicoprofiel}

Figuur 6.1

Sectoraal risicoprofiel

Energie

Geen scholing

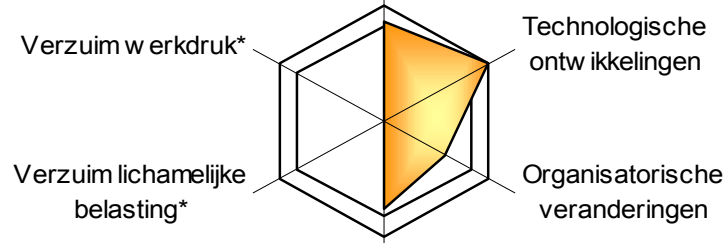

Uitstroomrisico

* geen betrouwbare informatie beschikbaar voor deze risicofactor

\section{Arbeidsomstandigheden}

Tabel 6.2

Percentage werkenden dat wordt geconfronteerd met lawaai tijdens het werk, 2000

\begin{tabular}{|c|c|c|c|}
\hline & $\%$ & typering & trend \\
\hline \multicolumn{4}{|l|}{ Bedrijfsgrootte } \\
\hline 10 tot 20 & - & - & sterk stijgend \\
\hline 20 tot 100 & 19 & gemiddeld & sterk dalend \\
\hline \multicolumn{4}{|l|}{ Beroep } \\
\hline Culturele beroepen & - & erg laag & - \\
\hline Agrarische beroepen & - & erg laag & - \\
\hline Technische en Industrieberoepen & 46 & erg hoog & sterk dalend \\
\hline Transportberoepen & - & erq laag & - \\
\hline Medische en Paramedische beroepen & - & erg laag & - \\
\hline Economisch-administratieve beroepen & - & erg laag & sterk stijgend \\
\hline Informaticaberoepen & - & erg laag & - \\
\hline Sociaal-culturele beroepen & - & erg laag & - \\
\hline Verzorgende en Dienstverlenende beroepen & - & erg hoog & - \\
\hline \multicolumn{4}{|l|}{ Opleiding } \\
\hline Basisonderwijs & - & erg laag & - \\
\hline VMBO Theorie & - & erg laag & - \\
\hline VMBO Landbouw en techniek & - & erg hoog & dalend \\
\hline VMBO Economie & - & erg hoog & - \\
\hline VMBO Verzorging & - & erg laag & _ \\
\hline HAVO/VWO & - & laag & - \\
\hline MBO Landbouw en techniek & 37 & erg hoog & dalend \\
\hline MBO Economie & - & gemiddeld & - \\
\hline MBO Dienstverlening en gezondheidszorg & - & erg hoog & - $\quad$ \\
\hline HO Landbouw en techniek & - & gemiddeld & stijgend \\
\hline HO Economie & - & erg laag & - \\
\hline HO Onderwijs en sociaal cultureel & - & erg laag & - \\
\hline HO (Para)medisch & - & erg laag & - \\
\hline
\end{tabular}

Bron: EBB (CBS), bewerking ROA 
Tabel 6.3

Percentage werkenden dat gebruik maakt van gereedschap of apparaten die trilling veroorzaken, 2000

\begin{tabular}{|c|c|c|c|}
\hline & $\%$ & typering & trend \\
\hline \multicolumn{4}{|l|}{ Bedrijfsgrootte } \\
\hline 20 tot 100 & 20 & hoog & constant \\
\hline \multicolumn{4}{|l|}{ Beroep } \\
\hline Culturele beroepen & - & laag & - \\
\hline Agrarische beroepen & - & laag & - \\
\hline Technische en Industrieberoepen & 50 & erg hoog & constant \\
\hline Transportberoepen & - & laag & - \\
\hline Medische en Paramedische beroepen & - & laag & - \\
\hline Economisch-administratieve beroepen & - & laag & - \\
\hline Informaticaberoepen & - & laag & - \\
\hline Sociaal-culturele beroepen & - & laag & - \\
\hline Verzorgende en Dienstverlenende beroepen & - & laag & - \\
\hline \multicolumn{4}{|l|}{ Opleiding } \\
\hline Basisonderwijs & - & laag & - \\
\hline VMBO Theorie & - & laag & - \\
\hline VMBO Landbouw en techniek & - & erg hoog & dalend \\
\hline VMBO Economie & - & erg hoog & - \\
\hline VMBO Verzorging & - & laag & - \\
\hline HAVO/ VWO & - & laag & - \\
\hline MBO Landbouw en techniek & 42 & erg hoog & stijgend \\
\hline MBO Economie & - & laag & - \\
\hline MBO Dienstverlening en gezondheidszorg & - & laag & - $\quad-2$ \\
\hline HO Landbouw en techniek & - & gemiddeld & sterk stijgend \\
\hline HO Economie & - & gemiddeld & - \\
\hline HO Onderwijs en sociaal cultureel & - & laag & - \\
\hline $\mathrm{HO}$ (Para)medisch & - & laag & - \\
\hline
\end{tabular}

Bron: EBB (CBS) 
Tabel 6.4

Percentage werkenden dat kracht moet zetten tijdens het werk, 2000

\begin{tabular}{|c|c|c|c|}
\hline & $\%$ & typering & trend \\
\hline \multicolumn{4}{|l|}{ Bedrijfsgrootte } \\
\hline 10 tot 20 & - & - & sterk dalend \\
\hline 20 tot 100 & 27 & gemiddeld & dalend \\
\hline \multicolumn{4}{|l|}{ Beroep } \\
\hline Culturele beroepen & - & erg laag & - \\
\hline Agrarische beroepen & - & erg laag & - \\
\hline Technische en Industrieberoepen & 58 & hoog & constant \\
\hline Transportberoepen & - & erg hoog & - \\
\hline Medische en Paramedische beroepen & - & erg laag & - \\
\hline Economisch-administratieve beroepen & - & erg laag & sterk dalend \\
\hline Informaticaberoepen & - & gemiddeld & - \\
\hline Sociaal-culturele beroepen & - & erg laag & - \\
\hline Verzorgende en Dienstverlenende beroepen & - & gemiddeld & - \\
\hline \multicolumn{4}{|l|}{ Opleiding } \\
\hline Basisonderwijs & - & laag & dalend \\
\hline VMBO Theorie & - & laag & - \\
\hline VMBO Landbouw en techniek & - & hoog & sterk dalend \\
\hline VMBO Economie & - & erg hoog & - \\
\hline VMBO Verzorging & - & erg hoog & - \\
\hline HAVO/VWO & - & erg laag & - \\
\hline MBO Landbouw en techniek & 53 & hoog & sterk dalend \\
\hline MBO Economie & - & erg laag & - \\
\hline MBO Dienstverlening en gezondheidszorg & - & erg laag & - \\
\hline HO Landbouw en techniek & - & laag & - \\
\hline HO Economie & - & erg laag & - \\
\hline HO Onderwijs en sociaal cultureel & - & erg laag & - \\
\hline $\mathrm{HO}$ (Para)medisch & - & erg laag & - \\
\hline
\end{tabular}

Bron: EBB (CBS) 
Tabel 6.5

Percentage werkenden dat onder hoge tijdsdruk werkt, 2000

\begin{tabular}{|c|c|c|c|}
\hline & $\%$ & typering & trend \\
\hline \multicolumn{4}{|l|}{ Bedrijfsgrootte } \\
\hline 10 tot 20 & - & - & stijgend \\
\hline 20 tot 100 & 63 & gemiddeld & sterk dalend \\
\hline \multicolumn{4}{|l|}{ Beroep } \\
\hline Culturele beroepen & - & erg laag & - \\
\hline Agrarische beroepen & - & erg hoog & - \\
\hline Technische en Industrieberoepen & 60 & gemiddeld & sterk dalend \\
\hline Transportberoepen & - & hoog & sterk dalend \\
\hline Medische en Paramedische beroepen & - & erg laag & - \\
\hline Economisch-administratieve beroepen & 70 & hoog & stijgend \\
\hline Informaticaberoepen & - & gemiddeld & dalend \\
\hline Sociaal-culturele beroepen & - & erg laag & - \\
\hline Verzorgende en Dienstverlenende beroepen & - & erg laag & - \\
\hline Openbare orde- en Veiligheidsberoepen & - & erg laag & - \\
\hline \multicolumn{4}{|l|}{ Opleiding } \\
\hline Basisonderwijs & - & erg laag & sterk dalend \\
\hline VMBO Theorie & - & gemiddeld & dalend \\
\hline VMBO Landbouw en techniek & - & erg laag & sterk dalend \\
\hline VMBO Economie & - & hoog & - \\
\hline VMBO Verzorging & - & erg hoog & - \\
\hline HAVO/VWO & - & erg hoog & sterk dalend \\
\hline MBO Landbouw en techniek & 60 & gemiddeld & dalend \\
\hline MBO Economie & - & erg hoog & constant \\
\hline MBO Dienstverlening en gezondheidszorg & - & erg laag & sterk dalend \\
\hline HO Landbouw en techniek & 69 & hoog & sterk dalend \\
\hline HO Economie & - & erg hoog & constant \\
\hline HO Onderwijs en sociaal cultureel & - & erg hoog & sterk stijgend \\
\hline $\mathrm{HO}$ (Para)medisch & - & erg laag & - \\
\hline
\end{tabular}

Bron: EBB (CBS) 
Tabel 6.6

Percentage werkenden dat als gevolg van klachten door lichamelijke belasting het werk heeft verzuimd, 1999

$\%$

typering

Beroep

Culturele beroepen

Technische en Industrieberoepen

Economisch-administratieve beroepen

Openbare orde- en Veiligheidsberoepen

erg laag

erg laag

- $\quad$ erg laag

- $\quad$ erg laag

Opleiding

Basisonderwijs

VMBO Theorie

- $\quad$ erg hoog

VMBO Landbouw en techniek

erg hoog

VMBO Economie

VMBO Verzorging

HAVO/ VWO

MBO Landbouw en techniek

MBO Economie

MBO Dienstverlening en gezondheidszorg

HO Landbouw en techniek

HO Economie

HO Onderwijs en sociaal cultureel

HO (Para)medisch

Bron: POLS (CBS)

Tabel 6.7

Percentage werkenden dat als gevolg van problemen met de werkdruk het werk heeft verzuimd, 1999

$\% \quad$ typering

Beroep

Culturele beroepen

Technische en Industrieberoepen

Economisch-administratieve beroepen

Openbare orde- en Veiligheidsberoepen

$\begin{aligned}- & \text { erg laag } \\ 20 & \text { erg hoog } \\ - & \text { erg laag }\end{aligned}$

Opleiding

MBO Landbouw en techniek

MBO Economie

MBO Dienstverlening en gezondheidszorg

HO Landbouw en techniek

HO Economie

HO Onderwijs en sociaal cultureel

HO (Para)medisch

Bron: POLS (CBS) 
Technologische en organisatorische ontwikkelingen

Tabel 6.8

Informatisering, 2000

\begin{tabular}{|c|c|c|c|}
\hline & $\%$ & typering & trend \\
\hline \multicolumn{4}{|l|}{ Bedrijfsgrootte } \\
\hline 5 tot 10 & - & erg hoog & - \\
\hline 10 tot 20 & - & hoog & constant \\
\hline 20 tot 100 & 85 & hoog & sterk dalend \\
\hline 500 of meer & - & laag & - \\
\hline \multicolumn{4}{|l|}{ Beroep } \\
\hline Culturele beroepen & - & erg hoog & - \\
\hline Agrarische beroepen & - & erg hoog & - \\
\hline Technische en Industrieberoepen & 65 & gemiddeld & sterk dalend \\
\hline Transportberoepen & - & erg laag & - \\
\hline Medische en Paramedische beroepen & - & gemiddeld & - \\
\hline Economisch-administratieve beroepen & 100 & erg hoog & stijgend \\
\hline Informaticaberoepen & - & erg hoog & - \\
\hline Sociaal-culturele beroepen & - & erg hoog & - \\
\hline Verzorgende en Dienstverlenende beroepen & - & erg laag & - \\
\hline \multicolumn{4}{|l|}{ Opleiding } \\
\hline Basisonderwijs & - & gemiddeld & dalend \\
\hline VMBO Theorie & - & hoog & - \\
\hline VMBO Landbouw en techniek & - & gemiddeld & sterk dalend \\
\hline VMBO Economie & - & erg hoog & - \\
\hline VMBO Verzorging & - & erg laag & - \\
\hline HAVO/ VWO & - & erg hoog & - \\
\hline MBO Landbouw en techniek & 74 & hoog & sterk dalend \\
\hline MBO Economie & - & erg hoog & - \\
\hline MBO Dienstverlening en gezondheidszorg & - & gemiddeld & - \\
\hline HO Landbouw en techniek & 95 & erg hoog & constant \\
\hline HO Economie & - & erg hoog & sterk stijgend \\
\hline HO Onderwijs en sociaal cultureel & - & erg hoog & sterk stijgend \\
\hline HO (Para)medisch & - & erg hoog & - \\
\hline
\end{tabular}

Bron: EBB (CBS) 
Ontwikkelingen in de structuur van de werkgelegenheid

Tabel 6.9

Uitstroomrisico, gemiddeld jaarlijks percentage, 1994-1998

$\%$

typering

Beroep

Technische en industrieberoepen

Economisch-administratieve beroepen

Informaticaberoepen

$4,1 \quad$ gemiddeld

Opleiding

VMBO overig

HAVO/VWO

MBO

$\mathrm{HBO}$

$\begin{array}{ll}0,0 & - \\ 8,3 & \text { hoog }\end{array}$

Bron: SEP (CBS)

\section{Scholingsinspanningen}

Tabel 6.10

Deelname aan bedrijfsopleidingen, 2000 (momentopname)

\begin{tabular}{llll}
\hline & typering & trend \\
\hline Beroep & & & \\
Culturele beroepen & - & erg laag & - \\
Agrarische beroepen & - & erg hoog & - \\
Technische en Industrieberoepen & - & erg hoog & sterk dalend \\
Transportberoepen & - & erg laag & - \\
Medische en Paramedische beroepen & - & erg laag & - \\
Economisch-administratieve beroepen & - & gemiddeld & dalend \\
Informaticaberoepen & - & gemiddeld & sterk dalend \\
Sociaal-culturele beroepen & - & erg laag & - \\
Verzorgende en Dienstverlenende beroepen & - & erg laag & - \\
Openbare orde- en Veiligheidsberoepen & - & erg laag & - \\
Opleiding & & & \\
Basisonderwijs & - & erg hoog & sterk dalend \\
VMBO Theorie & - & erg laag & - \\
VMBO Landbouw en techniek & - & erg hoog & sterk dalend \\
VMBO Economie & - & erg laag & - \\
VMBO Verzorging & - & erg laag & - \\
HAVO/ VWO & - & erg hoog & sterk stijgend \\
MBO Landbouw en techniek & - & erg hoog & constant \\
MBO Economie & - & erg laag & \\
MBO Dienstverlening en gezondheidszorg & - & erg laag & - \\
HO Landbouw en techniek & - & erg laag & sterk dalend \\
HO Economie & - & erg laag & sterk dalend \\
HO Onderwijs en sociaal cultureel & - & erg laag & - \\
HO (Para)medisch & - & erg laag & - \\
Bron: EBB (CBS) & & & \\
\hline & & &
\end{tabular}




\section{Doelgroepen voor scholingsbeleid}

Tabel 6.11

Risicogroepen binnen de sector per risicofactor

Lichamelijke belasting

Beroep

Opleiding

Psychische belasting

Beroep

Economisch- administratieve beroepen

Opleiding

Informatisering

Beroep

Opleiding

Ontwikkelingen in de structuur van de werkgelegenheid Beroep

Opleiding

Bron: ROA 

7. Bouw en onroerend goed 

Tabel 7.1

Kernindicatoren

\section{Arbeidsomstandigheden}

Belastende arbeidsomstandigheden

Lawaai

Trilling

Kracht zetten

Beeldschermwerk

Tijdsdruk

$\begin{array}{rr}\% & \text { typering } \\ 38 & \text { erg hoog } \\ 46 & \text { erg hoog } \\ 58 & \text { hoog } \\ 34 & \text { laag } \\ 55 & \text { gemiddeld } \\ & \\ 12 & \text { hoog } \\ 3 & \text { laag }\end{array}$

Verzuim vanwege lichamelijke belasting, percentage 1999

Verzuim vanwege de hoge werkdruk, percentage 1999

\section{Technologische en organisatorische ontwikkelingen}

Organisatorische ontwikkelingen

$1992-1994^{*}$

1994-1996*

$1996-1998$

$1992-1998$

Kleine veranderingen

Intensieve veranderingen

Veranderingen in positie

Interne reorganisaties

$8 \quad 6$

$5-3$

Technologische ontwikkelingen

11

FTE's ICT-personeel

$1997-2001^{*}$

Reële automatiseringskosten (euro)

$\begin{array}{lllll}0,11 & 0,11 & 0,18 & 0,20 & 0,22\end{array}$

$\begin{array}{lllll}19800 & 23100 & 23900 & 24000 & 24200\end{array}$

Aantal PC's**

Aantal PC's in netwerk ${ }^{* *}$

Aantal internet-PC's ${ }^{* *}$

$\begin{array}{rrrrrrr} & 7 & 9 & 9 & 10 & 11 & 9 \\ & 6 & 8 & 8 & 8 & 9 & 13 \\ & - & 2 & 2 & 4 & 5 & 38 \\ 1994 & 1995 & 1996 & 1997 & 1998 & 1999 & 1994-1999^{*} \\ 29 & 42 & 49 & 35 & 60 & 56 & 14\end{array}$

(verandering 1998-2001)

Ontwikkelingen in de structuur van de werkgelegenheid

Uitstroomrisico, 1994-1998*

Verwachte uitbreidingsvraag, 2001-2006*
1,7
5 trend
dalend

Flexibele arbeid, percentage 2000

\section{Scholingsdeelname}

Deelname aan bedrijfsopleidingen, percentage 2000 (momentopname)

typering

Cursusparticipatie, percentage 1998-2000

Bron: K\&E, POLS, Automatiseringsstatistieken (allen CBS), Arbeidsaanbod- en arbeidsvraagpanel (beiden OSA), POA (ROA)

* Gemiddelde jaarlijkse percentages

** Aantal per bedrijf 


\section{Risicoprofiel}

Figuur 7.1

Sectoraal risicoprofiel

\section{Bouw en onroerend goed}

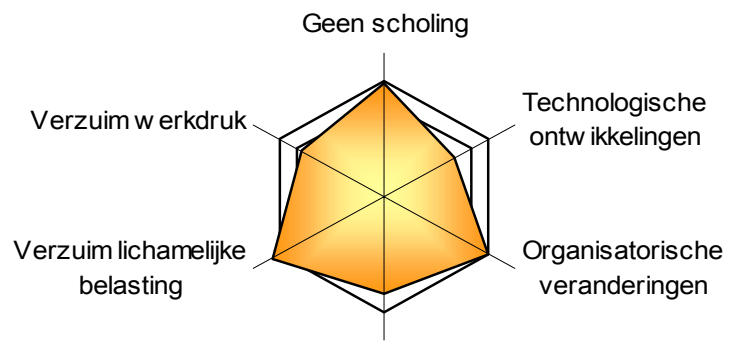

Uitstroomrisico

\section{Arbeidsomstandigheden}

Tabel 7.2

Percentage werkenden dat wordt geconfronteerd met lawaai tijdens het werk, 2000

\begin{tabular}{|c|c|c|c|}
\hline & $\%$ & typering & trend \\
\hline \multicolumn{4}{|l|}{ Bedrijfsgrootte } \\
\hline 5 tot 10 & 30 & hoog & sterk dalend \\
\hline 10 tot 20 & 41 & erg hoog & stijgend \\
\hline 20 tot 100 & 39 & erg hoog & dalend \\
\hline 500 of meer & 30 & hoog & - \\
\hline \multicolumn{4}{|l|}{ Beroep } \\
\hline Culturele beroepen & - & erg laag & - \\
\hline Agrarische beroepen & - & erg hoog & - \\
\hline Technische en Industrieberoepen & 48 & erg hoog & constant \\
\hline Transportberoepen & - & erg hoog & sterk stijgend \\
\hline Economisch-administratieve beroepen & - & erg laag & stijgend \\
\hline Informaticaberoepen & - & laag & - \\
\hline Sociaal-culturele beroepen & - & laag & - \\
\hline Verzorgende en Dienstverlenende beroepen & - & erg laag & - \\
\hline \multicolumn{4}{|l|}{ Opleiding } \\
\hline Basisonderwijs & 52 & erg hoog & stijgend \\
\hline VMBO Theorie & 26 & gemiddeld & sterk dalend \\
\hline VMBO Landbouw en techniek & 50 & erg hoog & dalend \\
\hline VMBO Economie & - & hoog & sterk dalend \\
\hline VMBO Verzorging & - & erg laag & - \\
\hline HAVO/ VWO & - & laag & sterk dalend \\
\hline MBO Landbouw en techniek & 45 & erg hoog & stijgend \\
\hline MBO Economie & - & laag & sterk dalend \\
\hline MBO Dienstverlening en gezondheidszorg & - & erg laag & - \\
\hline HO Landbouw en techniek & - & gemiddeld & sterk stijgend \\
\hline HO Economie & - & erg laag & - \\
\hline HO Onderwijs en sociaal cultureel & - & erg laag & - \\
\hline
\end{tabular}

Bron: EBB (CBS), bewerking ROA 
Tabel 7.3

Percentage werkenden dat gebruik maakt van gereedschap of apparaten die trilling veroorzaken, 2000

\begin{tabular}{|c|c|c|c|}
\hline & $\%$ & typering & trend \\
\hline \multicolumn{4}{|l|}{ Bedrijfsgrootte } \\
\hline 5 tot 10 & 53 & erg hoog & constant \\
\hline 10 tot 20 & 50 & erg hoog & stijgend \\
\hline 20 tot 100 & 36 & erg hoog & dalend \\
\hline 500 of meer & 45 & erg hoog & - \\
\hline \multicolumn{4}{|l|}{ Beroep } \\
\hline Culturele beroepen & - & laag & - \\
\hline Agrarische beroepen & - & erg hoog & - \\
\hline Technische en Industrieberoepen & 58 & erg hoog & constant \\
\hline Transportberoepen & - & erg hoog & sterk stijgend \\
\hline Economisch-administratieve beroepen & - & laag & sterk stijgend \\
\hline Informaticaberoepen & - & laag & - \\
\hline Sociaal-culturele beroepen & - & laag & - \\
\hline Verzorgende en Dienstverlenende beroepen & - & laag & - \\
\hline \multicolumn{4}{|l|}{ Opleiding } \\
\hline Basisonderwijs & 58 & erg hoog & stijgend \\
\hline VMBO Theorie & 34 & erg hoog & dalend \\
\hline VMBO Landbouw en techniek & 57 & erg hoog & dalend \\
\hline VMBO Economie & - & erg hoog & sterk dalend \\
\hline VMBO Verzorging & - & laag & - \\
\hline HAVO/ VWO & - & hoog & sterk stijgend \\
\hline MBO Landbouw en techniek & 57 & erg hoog & stijgend \\
\hline MBO Economie & - & laag & sterk dalend \\
\hline MBO Dienstverlening en gezondheidszorg & - & gemiddeld & sterk dalend \\
\hline HO Landbouw en techniek & - & laag & - \\
\hline HO Economie & - & laag & - \\
\hline HO Onderwijs en sociaal cultureel & - & laag & - \\
\hline
\end{tabular}

Bron: EBB (CBS) 
Tabel 7.4

Percentage werkenden dat kracht moet zetten tijdens het werk, 2000

$\% \quad$ typering trend

Bedrijfsgrootte

5 tot 10

10 tot 20

20 tot 100

500 of meer

$\begin{array}{lll}73 & \text { erg hoog } & \text { constant } \\ 62 & \text { erg hoog } & \text { stijgend } \\ 46 & \text { gemiddeld } & \text { dalend } \\ 58 & \text { hoog } & -\end{array}$

Beroep

Culturele beroepen

Agrarische beroepen

Technische en Industrieberoepen

Transportberoepen

Economisch-administratieve beroepen

Informaticaberoepen

Sociaal-culturele beroepen

Verzorgende en Dienstverlenende beroepen

$\begin{array}{rll}- & \text { erg hoog } & - \\ - & \text { erg hoog } & \text { sterk stijgend } \\ 72 & \text { erg hoog } & \text { constant } \\ - & \text { erg hoog } & \text { sterk stijgend } \\ - & \text { erg laag } & \text { sterk stijgend } \\ - & \text { laag } & - \\ - & \text { gemiddeld } & - \\ - & \text { gemiddeld } & \text { sterk dalend }\end{array}$

Opleiding

Basisonderwijs

VMBO Theorie

VMBO Landbouw en techniek

VMBO Economie

VMBO Verzorging

HAVO/ VWO

MBO Landbouw en techniek

MBO Economie

MBO Dienstverlening en gezondheidszorg

HO Landbouw en techniek

HO Economie

HO Onderwijs en sociaal cultureel

$\begin{array}{cll}81 & \text { erg hoog } & \text { stijgend } \\ 43 & \text { gemiddeld } & \text { sterk dalend } \\ 78 & \text { erg hoog } & \text { dalend } \\ 65 & \text { erg hoog } & \text { sterk dalend } \\ - & \text { laag } & - \\ - & \text { gemiddeld } & \text { sterk stijgend } \\ 66 & \text { erg hoog } & \text { stijgend } \\ - & \text { erg laag } & \text { sterk dalend } \\ - & \text { laag } & \text { sterk dalend } \\ - & \text { erg laag } & \text { sterk stijgend } \\ - & \text { erg laag } & - \\ - & \text { erg laag } & -\end{array}$

Bron: EBB (CBS) 
Tabel 7.5

Percentage werkenden dat onder hoge tijdsdruk werkt, 2000

$\% \quad$ typering trend

Bedrijfsgrootte

5 tot 10

10 tot 20

20 tot 100

500 of meer

$\begin{array}{lll}39 & \text { erg laag } & \text { dalend } \\ 54 & \text { laag } & \text { constant } \\ 63 & \text { gemiddeld } & \text { constant } \\ 40 & \text { erg laag } & -\end{array}$

Beroep

Pedagogische beroepen

Culturele beroepen

Agrarische beroepen

Technische en Industrieberoepen

Transportberoepen

Medische en Paramedische beroepen

Economisch-administratieve beroepen

Informaticaberoepen

Sociaal-culturele beroepen

Verzorgende en Dienstverlenende beroepen

Openbare orde- en Veiligheidsberoepen

Opleiding

Basisonderwijs

VMBO Theorie

VMBO Landbouw en techniek

VMBO Economie

VMBO Verzorging

HAVO/ VWO

MBO Landbouw en techniek

MBO Economie

MBO Dienstverlening en gezondheidszorg

$\mathrm{HO}$ Landbouw en techniek

HO Economie

$\mathrm{HO}$ Onderwijs en sociaal cultureel

HO (Para)medisch

$\begin{array}{rll}- & \text { erg hoog } & - \\ - & \text { gemiddeld } & - \\ - & \text { erg laag } & \text { stijgend } \\ 54 & \text { laag } & \text { constant } \\ - & \text { laag } & \text { stijgend } \\ - & \text { erg laag } & - \\ 59 & \text { gemiddeld } & \text { constant } \\ - & \text { gemiddeld } & \text { sterk stijgend } \\ - & \text { erg hoog } & \text { sterk dalend } \\ - & \text { erg laag } & \text { constant } \\ - & \text { erg hoog } & -\end{array}$

$\begin{array}{rll}49 & \text { laag } & \text { stijgend } \\ 43 & \text { erg laag } & \text { sterk dalend } \\ 50 & \text { laag } & \text { dalend } \\ 63 & \text { gemiddeld } & \text { dalend } \\ - & \text { erg laag } & \text { sterk dalend } \\ 51 & \text { laag } & \text { sterk stijgend } \\ 58 & \text { gemiddeld } & \text { dalend } \\ 43 & \text { erg laag } & \text { sterk dalend } \\ - & \text { erg laag } & \text { stijgend } \\ 75 & \text { erg hoog } & \text { sterk stijgend } \\ 76 & \text { erg hoog } & \text { sterk stijgend } \\ - & \text { laag } & \text { dalend } \\ - & \text { erg hoog } & -\end{array}$

Bron: EBB (CBS) 
Tabel 7.6

Percentage werkenden dat als gevolg van klachten door lichamelijke belasting het werk heeft verzuimd, 1999

typering

Beroep

Agrarische beroepen

Technische en Industrieberoepen

Transportberoepen

Economisch-administratieve beroepen

Verzorgende en Dienstverlenende beroepen

Openbare orde- en Veiligheidsberoepen

- $\quad$ erg laag

erg hoog

- erg laag

$3 \quad$ laag

5 erg hoog

Opleiding

Basisonderwijs

erg hoog

VMBO Theorie

VMBO Landbouw en techniek

erg laag

VMBO Economie

VMBO Verzorging

HAVO/ VWO

MBO Landbouw en techniek

MBO Economie

MBO Dienstverlening en gezondheidszorg

HO Landbouw en techniek

HO Economie

HO Onderwijs en sociaal culturee

HO (Para)medisch

erg hoog

erg hoog

hoog

erg hoog

erg laag

erg laag

hoog

erg hoog

erg laag

erg laag

erg laag

erg laag

erg hoog

Bron: POLS (CBS)

Tabel 7.7

Percentage werkenden dat als gevolg van problemen met de werkdruk het werk heeft verzuimd, 1999

typering

Beroep

Agrarische beroepen

Technische en Industrieberoepen

Transportberoepen

Economisch-administratieve beroepen

Verzorgende en Dienstverlenende beroepen

Openbare orde- en Veiligheidsberoepen

erg laag

$4 \quad$ laag

erg laag

erg hoog

Opleiding

Basisonderwijs

erg laag

VMBO Theorie

VMBO Landbouw en techniek

VMBO Economie

VMBO Verzorging

HAVO/ VWO

MBO Landbouw en techniek

MBO Economie

MBO Dienstverlening en gezondheidszorg

HO Landbouw en techniek

HO Economie

HO Onderwijs en sociaal cultureel

erg hoog

erg laag

erg laag

erg laag

erg laag

erg laag

laag

erg laag

erg laag

erg hoog

erg laag

erg laag

Bron: POLS (CBS) 
Technologische en organisatorische ontwikkelingen

Tabel 7.8

Informatisering, 2000

\begin{tabular}{|c|c|c|c|}
\hline & $\%$ & typering & trend \\
\hline \multicolumn{4}{|l|}{ Bedrijfsgrootte } \\
\hline 5 tot 10 & 25 & laag & stijgend \\
\hline 10 tot 20 & 27 & laag & stijgend \\
\hline 20 tot 100 & 48 & gemiddeld & stijgend \\
\hline 100 tot 500 & - & erg laag & - \\
\hline 500 of meer & - & laag & - \\
\hline \multicolumn{4}{|l|}{ Beroep } \\
\hline Culturele beroepen & - & erg hoog & - \\
\hline Agrarische beroepen & - & laag & - \\
\hline Technische en Industrieberoepen & 17 & erg laag & stijgend \\
\hline Transportberoepen & - & erg laag & dalend \\
\hline Economisch-administratieve beroepen & 93 & erg hoog & stijgend \\
\hline Informaticaberoepen & 100 & erg hoog & - \\
\hline Sociaal-culturele beroepen & - & erg hoog & sterk stijgend \\
\hline Verzorgende en Dienstverlenende beroepen & - & gemiddeld & sterk stijgend \\
\hline \multicolumn{4}{|l|}{ Opleiding } \\
\hline Basisonderwijs & 10 & erg laag & sterk stijgend \\
\hline VMBO Theorie & 49 & gemiddeld & sterk stijgend \\
\hline VMBO Landbouw en techniek & 6 & erg laag & sterk dalend \\
\hline VMBO Economie & - & erg laag & sterk stijgend \\
\hline VMBO Verzorging & - & hoog & - \\
\hline HAVO/ VWO & 66 & gemiddeld & stijgend \\
\hline MBO Landbouw en techniek & 27 & laag & sterk stijgend \\
\hline MBO Economie & 87 & hoog & dalend \\
\hline MBO Dienstverlening en gezondheidszorg & - & hoog & stijgend \\
\hline HO Landbouw en techniek & 97 & erg hoog & constant \\
\hline HO Economie & 80 & hoog & sterk stijgend \\
\hline HO Onderwijs en sociaal cultureel & 89 & hoog & - \\
\hline
\end{tabular}

Bron: EBB (CBS) 
Ontwikkelingen in de structuur van de werkgelegenheid

Tabel 7.9

Uitstroomrisico, gemiddeld jaarlijks percentage, 1994-1998

$\%$

typering

Beroep

Technische en industrieberoepen

Economisch-administratieve beroepen

Sociaal-culturele beroepen

Verzorgende en dienstverlenende beroepen

gemiddeld

Opleiding

Basisonderwijs $\quad 4,8$

$\begin{array}{ll}\text { VMBO theorie } & 2,9 \\ \text { VMBO overig } & 4,8\end{array}$

HAVO/VWO

MBO $\quad 3,5$

$\mathrm{HBO} \quad 3,9$

WO $\quad 0,0$

$0,0 \quad-$

6emiddeld

Bron: SEP (CBS)

\section{Scholingsinspanningen}

Tabel 7.10

Deelname aan bedrijfsopleidingen, 2000 (momentopname)

$\% \quad$ typering trend

\section{Beroep}

Pedagogische beroepen

Culturele beroepen

Agrarische beroepen

Technische en Industrieberoepen

Transportberoepen

Medische en Paramedische beroepen

Economisch-administratieve beroepen

Informaticaberoepen

Sociaal-culturele beroepen

Verzorgende en Dienstverlenende beroepen

Openbare orde- en Veiligheidsberoepen

Opleiding

Basisonderwijs

VMBO Theorie

VMBO Landbouw en techniek

VMBO Economie

VMBO Verzorging

$\mathrm{HAVO} / \mathrm{VWO}$

MBO Landbouw en techniek

MBO Economie

MBO Dienstverlening en gezondheidszorg

HO Landbouw en techniek

HO Economie

HO Onderwijs en sociaal cultureel

$\mathrm{HO}$ (Para)medisch

$\begin{array}{lll}- & \text { erg hoog } & - \\ - & \text { erg laag } & - \\ - & \text { erg hoog } & - \\ 5 & \text { laag } & \text { dalend } \\ - & \text { gemiddeld } & \text { sterk stijgend } \\ - & \text { erg laag } & - \\ - & \text { laag } & \text { stijgend } \\ - & \text { erg hoog } & \text { sterk stijgend } \\ - & \text { erg hoog } & - \\ - & \text { erg laag } & - \\ - & \text { erg laag } & - \\ & & \\ & & \\ - & \text { laag } & \text { sterk stijgend } \\ - & \text { laag } & \text { sterk dalend } \\ - & \text { laag } & \text { sterk dalend } \\ - & \text { erg laag } & \\ - & \text { erg laag } & - \\ - & \text { erg laag } & \text { sterk stijgend } \\ 7 & \text { gemiddeld } & \text { stijgend } \\ - & \text { laag } & \text { constant } \\ - & \text { erg hoog } & \\ - & \text { laag } & \text { stijgend } \\ - & \text { erg laag } & \text { sterk dalend } \\ - & \text { erg laag } & - \\ - & \text { erg laag } & - \\ & & \end{array}$

Bron: EBB (CBS) 


\section{Doelgroepen voor scholingsbeleid}

Tabel 7.11

Risicogroepen binnen de sector per risicofactor

Lichamelijke belasting

Beroep

Verzorgende en Dienstverlenende beroepen

Opleiding

VMBO economie

Psychische belasting

Beroep

Opleiding

Informatisering

Beroep

Opleiding

Ontwikkelingen in de structuur van de werkgelegenheid Beroep

Opleiding

Bron: ROA 

8. Handel en reparatie 

Tabel 8.1

Kernindicatoren

\section{Arbeidsomstandigheden}

Belastende arbeidsomstandigheden

$\begin{array}{rr}\% & \text { typering } \\ & \\ 14 & \text { laag } \\ 11 & \text { gemiddeld } \\ 45 & \text { gemiddeld } \\ 56 & \text { gemiddeld } \\ 51 & \text { laag } \\ & \\ 7 & \text { gemiddeld } \\ 5 & \text { gemiddeld }\end{array}$

Lawaai

Trilling

Kracht zetten

Beeldschermwerk

Tijdsdruk

gemiddeld

\section{Technologische en organisatorische ontwikkelingen}

\begin{tabular}{|c|c|c|c|c|c|c|}
\hline Organisatorische ontwikkelingen & $992-1994^{*}$ & & $4-1996^{*}$ & \multicolumn{2}{|c|}{$1996-1998^{*}$} & $1992-1998^{*}$ \\
\hline Kleine veranderingen & 17 & & 8 & & 9 & 6 \\
\hline Intensieve veranderingen & 9 & & 6 & & 6 & 4 \\
\hline Veranderingen in positie & 7 & & 35 & & 8 & 8 \\
\hline Interne reorganisaties & 7 & & 20 & & 17 & 7 \\
\hline Technologische ontwikkelingen & 1997 & 1998 & 1999 & 2000 & 2001 & $1997-2001^{*}$ \\
\hline FTE's ICT-personeel & 0,38 & 0,42 & 0,53 & 0,56 & 0,60 & 12 \\
\hline Reële automatiseringskosten (euro) & 46900 & 57700 & 64400 & 63300 & 65000 & \\
\hline Aantal PC's** & 10 & 12 & 14 & 15 & 16 & 11 \\
\hline Aantal PC's in netwerk ${ }^{* *}$ & 9 & 10 & 11 & 12 & 13 & 11 \\
\hline Aantal internet-PC's** & - & 4 & 4 & 6 & 7 & 0 \\
\hline 1994 & 1995 & 1996 & 1997 & 1998 & 1999 & 1994-199 \\
\hline Reële R\&D uitgaven & 109 & 134 & 151 & 167 & 192 & \\
\hline
\end{tabular}

Ontwikkelingen in de structuur van de werkgelegenheid

Uitstroomrisico, 1994-1998*

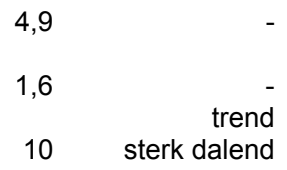

Flexibele arbeid, percentage 2000

typering

\section{Scholingsdeelname}

Deelname aan bedrijfsopleidingen, percentage 2000 (momentopname)

Cursusparticipatie, percentage 1998-2000

Bron: K\&E, POLS, Automatiseringsstatistieken (allen CBS), Arbeidsaanbod- en arbeidsvraagpanel (beiden OSA), POA (ROA)

* Gemiddelde jaarlijkse percentages

** Aantal per bedrijf 


\section{Risicoprofiel}

Figuur 8.1

Sectoraal risicoprofiel

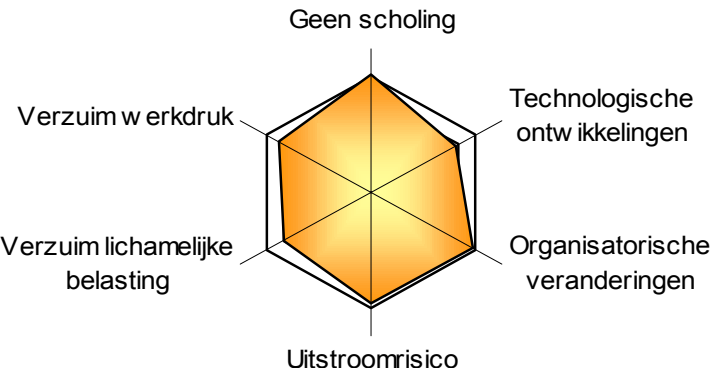

\section{Handel en reparatie}

Uitstroomrisico

\section{Arbeidsomstandigheden}

Tabel 8.2

Percentage werkenden dat wordt geconfronteerd met lawaai tijdens het werk, 2000

\begin{tabular}{|c|c|c|c|}
\hline & $\%$ & typering & trend \\
\hline \multicolumn{4}{|l|}{ Bedrijfsgrootte } \\
\hline 5 tot 10 & 11 & laag & sterk dalend \\
\hline 10 tot 20 & 17 & gemiddeld & sterk stijgend \\
\hline 20 tot 100 & 14 & laag & dalend \\
\hline 500 of meer & - & gemiddeld & - \\
\hline \multicolumn{4}{|l|}{ Beroep } \\
\hline Pedagogische beroepen & - & erg hoog & - \\
\hline Culturele beroepen & - & erg laag & - \\
\hline Agrarische beroepen & - & gemiddeld & sterk stijgend \\
\hline Technische en Industrieberoepen & 41 & erg hoog & constant \\
\hline Transportberoepen & 24 & gemiddeld & constant \\
\hline Medische en Paramedische beroepen & - & erg laag & - \\
\hline Economisch-administratieve beroepen & 8 & erg laag & constant \\
\hline Informaticaberoepen & - & erg laag & - \\
\hline Sociaal-culturele beroepen & - & erg laag & - \\
\hline Verzorgende en Dienstverlenende beroepen & 8 & erg laag & stijgend \\
\hline Openbare orde- en Veiligheidsberoepen & - & - & - \\
\hline \multicolumn{4}{|l|}{ Opleiding } \\
\hline Basisonderwijs & 18 & gemiddeld & stijgend \\
\hline VMBO Theorie & 12 & laag & stijgend \\
\hline VMBO Landbouw en techniek & 19 & gemiddeld & sterk dalend \\
\hline VMBO Economie & - & gemiddeld & stijgend \\
\hline VMBO Verzorging & 12 & laag & sterk stijgend \\
\hline HAVO/ VWO & 13 & laag & sterk stijgend \\
\hline MBO Landbouw en techniek & 27 & hoog & constant \\
\hline MBO Economie & 7 & erg laag & sterk dalend \\
\hline MBO Dienstverlening en gezondheidszorg & 12 & laag & sterk stijgend \\
\hline HO Landbouw en techniek & - & laag & sterk stijgend \\
\hline HO Economie & - & erg laag & sterk dalend \\
\hline HO Onderwijs en sociaal cultureel & - & laag & stijgend \\
\hline HO (Para)medisch & - & gemiddeld & - \\
\hline
\end{tabular}

Bron: EBB (CBS), bewerking ROA 
Tabel 8.3

Percentage werkenden dat gebruik maakt van gereedschap of apparaten die trilling veroorzaken, 2000

\begin{tabular}{|c|c|c|c|}
\hline & $\%$ & typering & trend \\
\hline \multicolumn{4}{|l|}{ Bedrijfsgrootte } \\
\hline 5 tot 10 & 18 & gemiddeld & stijgend \\
\hline 10 tot 20 & 11 & gemiddeld & constant \\
\hline 20 tot 100 & 7 & gemiddeld & constant \\
\hline \multicolumn{4}{|l|}{ Beroep } \\
\hline Pedagogische beroepen & - & erg hoog & - \\
\hline Culturele beroepen & - & laag & - \\
\hline Agrarische beroepen & - & gemiddeld & sterk stijgend \\
\hline Technische en Industrieberoepen & 49 & erg hoog & stijgend \\
\hline Transportberoepen & - & laag & sterk dalend \\
\hline Medische en Paramedische beroepen & - & hoog & sterk stijgend \\
\hline Economisch-administratieve beroepen & 2 & laag & stijgend \\
\hline Informaticaberoepen & - & laag & - \\
\hline Sociaal-culturele beroepen & - & laag & - \\
\hline Verzorgende en Dienstverlenende beroepen & 4 & laag & constant \\
\hline \multicolumn{4}{|l|}{ Opleiding } \\
\hline Basisonderwijs & 12 & gemiddeld & sterk stijgend \\
\hline VMBO Theorie & 7 & gemiddeld & sterk stijgend \\
\hline VMBO Landbouw en techniek & 19 & hoog & sterk dalend \\
\hline VMBO Economie & - & erg hoog & sterk stijgend \\
\hline VMBO Verzorging & - & laag & - \\
\hline HAVO/ VWO & - & laag & sterk dalend \\
\hline MBO Landbouw en techniek & 28 & erg hoog & constant \\
\hline MBO Economie & 6 & laag & stijgend \\
\hline MBO Dienstverlening en gezondheidszorg & 10 & gemiddeld & sterk stijgend \\
\hline HO Landbouw en techniek & - & laag & - \\
\hline HO Economie & - & laag & - \\
\hline HO Onderwijs en sociaal cultureel & - & laag & - \\
\hline $\mathrm{HO}$ (Para)medisch & - & laag & - \\
\hline
\end{tabular}

Bron: EBB (CBS) 
Tabel 8.4

Percentage werkenden dat kracht moet zetten tijdens het werk, 2000

\begin{tabular}{|c|c|c|c|}
\hline & $\%$ & typering & trend \\
\hline \multicolumn{4}{|l|}{ Bedrijfsgrootte } \\
\hline 5 tot 10 & 52 & hoog & sterk stijgend \\
\hline 10 tot 20 & 44 & gemiddeld & sterk stijgend \\
\hline 20 tot 100 & 43 & gemiddeld & constant \\
\hline 500 of meer & - & laag & - \\
\hline \multicolumn{4}{|l|}{ Beroep } \\
\hline Pedagogische beroepen & - & erg hoog & - \\
\hline Culturele beroepen & - & erg laag & - \\
\hline Agrarische beroepen & 49 & hoog & sterk stijgend \\
\hline Technische en Industrieberoepen & 70 & erg hoog & constant \\
\hline Transportberoepen & 79 & erg hoog & constant \\
\hline Medische en Paramedische beroepen & 26 & laag & sterk stijgend \\
\hline Economisch-administratieve beroepen & 18 & laag & sterk stijgend \\
\hline Informaticaberoepen & - & erg laag & sterk dalend \\
\hline Sociaal-culturele beroepen & - & laag & - \\
\hline Verzorgende en Dienstverlenende beroepen & 54 & hoog & sterk stijgend \\
\hline \multicolumn{4}{|l|}{ Opleiding } \\
\hline Basisonderwijs & 64 & erg hoog & sterk stijgend \\
\hline VMBO Theorie & 46 & gemiddeld & stijgend \\
\hline VMBO Landbouw en techniek & 58 & hoog & dalend \\
\hline VMBO Economie & 52 & hoog & dalend \\
\hline VMBO Verzorging & 52 & hoog & sterk stijgend \\
\hline HAVO/VWO & 34 & gemiddeld & dalend \\
\hline MBO Landbouw en techniek & 53 & hoog & stijgend \\
\hline MBO Economie & 43 & gemiddeld & stijgend \\
\hline MBO Dienstverlening en gezondheidszorg & 40 & gemiddeld & sterk stijgend \\
\hline HO Landbouw en techniek & - & laag & sterk stijgend \\
\hline HO Economie & _- & erg laag & dalend \\
\hline HO Onderwijs en sociaal cultureel & - & laag & constant \\
\hline HO (Para)medisch & _- & laag & - \\
\hline
\end{tabular}

Bron: EBB (CBS) 
Tabel 8.5

Percentage werkenden dat onder hoge tijdsdruk werkt, 2000

$\% \quad$ typering trend

Bedrijfsgrootte

5 tot 10

10 tot 20

20 tot 100

100 tot 500

500 of meer

$\begin{array}{rll}37 & \text { erg laag } & \text { constant } \\ 52 & \text { laag } & \text { constant } \\ 59 & \text { gemiddeld } & \text { dalend } \\ - & - & \text { sterk dalend } \\ 32 & \text { erg laag } & - \\ & & \\ & & \\ - & \text { erg hoog } & \text { dalend } \\ - & \text { gemiddeld } & \text { sterk dalend } \\ 54 & \text { laag } & \text { sterk dalend } \\ 57 & \text { gemiddeld } & \text { dalend } \\ 52 & \text { laag } & \text { constant } \\ 51 & \text { laag } & \text { sterk dalend } \\ 60 & \text { gemiddeld } & \text { dalend } \\ 72 & \text { hoog } & \text { constant } \\ - & \text { erg hoog } & \text { stijgend } \\ 40 & \text { erg laag } & \text { stijgend } \\ - & \text { laag } & - \\ & & \\ 43 & \text { erg laag } & \text { stijgend } \\ 45 & \text { erg laag } & \text { stijgend } \\ 47 & \text { erg laag } & \text { dalend } \\ 64 & \text { gemiddeld } & \text { sterk dalend } \\ 38 & \text { erg laag } & \text { constant } \\ 45 & \text { erg laag } & \text { dalend } \\ 58 & \text { gemiddeld } & \text { constant } \\ 53 & \text { laag } & \text { dalend } \\ 45 & \text { erg laag } & \text { constant } \\ 75 & \text { erg hoog } & \text { sterk dalend } \\ 70 & \text { hoog } & \text { dalend } \\ 63 & \text { gemiddeld } & \text { stijgend } \\ - & \text { laag } & \text { sterk stijgend }\end{array}$

Beroep

Pedagogische beroepen

Culturele beroepen

Agrarische beroepen

Technische en Industrieberoepen

Transportberoepen

Medische en Paramedische beroepen

Economisch-administratieve beroepen

Informaticaberoepen

Sociaal-culturele beroepen

Verzorgende en Dienstverlenende beroepen

Openbare orde- en Veiligheidsberoepen

Opleiding

Basisonderwijs

VMBO Theorie

VMBO Landbouw en techniek

VMBO Economie

VMBO Verzorging

HAVO/ VWO

MBO Landbouw en techniek

MBO Economie

MBO Dienstverlening en gezondheidszorg

$\mathrm{HO}$ Landbouw en techniek

$\mathrm{HO}$ Economie

HO Onderwijs en sociaal cultureel

HO (Para)medisch

laag

end

Bron: EBB (CBS) 
Tabel 8.6

Percentage werkenden dat als gevolg van klachten door lichamelijke belasting het werk heeft verzuimd, 1999

typering

\section{Beroep}

Culturele beroepen

Agrarische beroepen

Technische en Industrieberoepen

Transportberoepen

Medische en Paramedische beroepen

Economisch-administratieve beroepen

Informaticaberoepen

Sociaal-culturele beroepen

Verzorgende en Dienstverlenende beroepen

$8 \quad$ erg laag

gemiddeld

erg hoog

erg laag

gemiddeld

60 erg hoog

erg laag

Opleiding

Basisonderwijs

VMBO Theorie

VMBO Landbouw en techniek

VMBO Economie

VMBO Verzorging

HAVO/ VWO

MBO Landbouw en techniek

MBO Economie

MBO Dienstverlening en gezondheidszorg

$\mathrm{HO}$ Landbouw en techniek

HO Economie

$\mathrm{HO}$ Onderwijs en sociaal cultureel

gemiddeld

HO (Para)medisch

erg hoog

hoog

hoog

erg laag

gemiddeld

gemiddeld

gemiddeld

gemiddeld

gemiddeld

gemiddeld

erg laag

erg laag

Bron: POLS (CBS)

erg laag 
Tabel 8.7

Percentage werkenden dat als gevolg van problemen met de werkdruk het werk heeft verzuimd, 1999

$\% \quad$ typering

Beroep

Culturele beroepen

Agrarische beroepen

Technische en Industrieberoepen

Transportberoepen

Medische en Paramedische beroepen

Economisch-administratieve beroepen

Informaticaberoepen

Sociaal-culturele beroepen

Verzorgende en Dienstverlenende beroepen

Opleiding

Basisonderwijs

VMBO Theorie

VMBO Landbouw en techniek

VMBO Economie

VMBO Verzorging

HAVO/ VWO

MBO Landbouw en techniek

MBO Economie

MBO Dienstverlening en gezondheidszorg

HO Landbouw en techniek

HO Economie

$\mathrm{HO}$ Onderwijs en sociaal cultureel

$\mathrm{HO}$ (Para)medisch

erg laag

erg hoog

laag

erg hoog

erg laag

gemiddeld

erg laag

erg laag

gemiddeld

erg hoog

gemiddeld

hoog

erg laag

erg hoog

erg hoog

erg laag

laag

laag

erg laag

erg laag

erg laag

erg laag

Bron: POLS (CBS) 
Technologische en organisatorische ontwikkelingen

Tabel 8.8

Informatisering, 2000

\begin{tabular}{|c|c|c|c|}
\hline & $\%$ & typering & trend \\
\hline \multicolumn{4}{|l|}{ Bedrijfsgrootte } \\
\hline 5 tot 10 & 39 & laag & stijgend \\
\hline 10 tot 20 & 60 & gemiddeld & sterk stijgend \\
\hline 20 tot 100 & 63 & gemiddeld & constant \\
\hline 100 tot 500 & - & gemiddeld & - \\
\hline 500 of meer & 37 & laag & - \\
\hline \multicolumn{4}{|l|}{ Beroep } \\
\hline Pedagogische beroepen & - & erg hoog & - \\
\hline Culturele beroepen & _ & erg hoog & - \\
\hline Agrarische beroepen & - & laag & sterk stijgend \\
\hline Technische en Industrieberoepen & 35 & laag & dalend \\
\hline Transportberoepen & 39 & laag & sterk stijgend \\
\hline Medische en Paramedische beroepen & 93 & erg hoog & stijgend \\
\hline Economisch-administratieve beroepen & 88 & hoog & stijgend \\
\hline Informaticaberoepen & 100 & erg hoog & - \\
\hline Sociaal-culturele beroepen & 100 & erg hoog & sterk stijgend \\
\hline Verzorgende en Dienstverlenende beroepen & 38 & laag & stijgend \\
\hline \multicolumn{4}{|l|}{ Opleiding } \\
\hline Basisonderwijs & 29 & laag & sterk stijgend \\
\hline VMBO Theorie & 51 & gemiddeld & sterk stijgend \\
\hline VMBO Landbouw en techniek & 46 & gemiddeld & stijgend \\
\hline VMBO Economie & 46 & gemiddeld & sterk stijgend \\
\hline VMBO Verzorging & 20 & erg laag & stijgend \\
\hline HAVO/ VWO & 65 & gemiddeld & constant \\
\hline MBO Landbouw en techniek & 56 & gemiddeld & constant \\
\hline MBO Economie & 67 & gemiddeld & constant \\
\hline MBO Dienstverlening en gezondheidszorg & 61 & gemiddeld & constant \\
\hline HO Landbouw en techniek & 92 & erg hoog & dalend \\
\hline HO Economie & 93 & erg hoog & stijgend \\
\hline HO Onderwijs en sociaal cultureel & 71 & hoog & stijgend \\
\hline $\mathrm{HO}$ (Para)medisch & 100 & erg hoog & sterk stijgend \\
\hline
\end{tabular}

Bron: EBB (CBS) 
Ontwikkelingen in de structuur van de werkgelegenheid

Tabel 8.9

Uitstroomrisico, gemiddeld jaarlijks percentage, 1994-1998

\begin{tabular}{lcc}
\hline & $\%$ & typering \\
\hline Beroep & & \\
Agrarische beroepen & 0,0 & - \\
Technische en industrieberoepen & 4,9 & gemiddeld \\
Transportberoepen & 4,9 & gemiddeld \\
Medische en paramedische beroepen & 2,6 & laag \\
Economisch-administratieve beroepen & 3,7 & gemiddeld \\
Informaticaberoepen & 0,0 & - \\
Verzorgende en dienstverlenende beroepen & 6,3 & gemiddeld \\
Opleiding & & \\
Basisonderwijs & & \\
VMBO theorie & 7,6 & gemiddeld \\
VMBO overig & 6,5 & gemiddeld \\
HAVO/VWO & 7,1 & gemiddeld \\
MBO & 5,3 & gemiddeld \\
HBO & 3,8 & gemiddeld \\
WO & 3,6 & gemiddeld \\
& 2,7 & gemiddeld \\
\hline Bron: SEP (CBS) & & \\
\hline
\end{tabular}

Bron: SEP (CBS)

\section{Scholingsinspanningen}

Tabel 8.10

Deelname aan bedrijfsopleidingen, 2000 (momentopname)

\begin{tabular}{|c|c|c|c|}
\hline & $\%$ & typering & trend \\
\hline \multicolumn{4}{|l|}{ Beroep } \\
\hline Pedagogische beroepen & - & erg hoog & - \\
\hline Culturele beroepen & _- & erg laag & - \\
\hline Agrarische beroepen & - & erg laag & constant \\
\hline Technische en Industrieberoepen & 7 & gemiddeld & dalend \\
\hline Transportberoepen & - & erg laag & sterk stijgend \\
\hline Medische en Paramedische beroepen & - & erg hoog & sterk stijgend \\
\hline Economisch-administratieve beroepen & 5 & laag & stijgend \\
\hline Informaticaberoepen & - & gemiddeld & sterk dalend \\
\hline Sociaal-culturele beroepen & - & laag & - \\
\hline Verzorgende en Dienstverlenende beroepen & 4 & erg laag & stijgend \\
\hline Openbare orde- en Veiligheidsberoepen & - & erg hoog & - \\
\hline \multicolumn{4}{|l|}{ Opleiding } \\
\hline Basisonderwijs & _- & laag & sterk stijgend \\
\hline VMBO Theorie & - & erg laag & sterk stijgend \\
\hline VMBO Landbouw en techniek & _- & erg laag & sterk dalend \\
\hline VMBO Economie & - & erg laag & sterk stijgend \\
\hline VMBO Verzorging & - & erg laag & sterk stijgend \\
\hline HAVO/ VWO & - & erg laag & sterk stijgend \\
\hline MBO Landbouw en techniek & 7 & hoog & constant \\
\hline MBO Economie & 5 & laag & constant \\
\hline MBO Dienstverlening en gezondheidszorg & - & laag & constant \\
\hline HO Landbouw en techniek & - & erg hoog & sterk stijgend \\
\hline HO Economie & _- & erg laag & sterk dalend \\
\hline HO Onderwijs en sociaal cultureel & - & hoog & sterk stijgend \\
\hline HO (Para)medisch & _- & hoog & sterk stijgend \\
\hline
\end{tabular}

Bron: EBB (CBS) 


\section{Doelgroepen voor scholingsbeleid}

Tabel 8.11

Risicogroepen binnen de sector per risicofactor

Lichamelijke belasting

Beroep

Informaticaberoepen

Opleiding

Psychische belasting

Beroep

Opleiding

Informatisering

Beroep

Opleiding

Ontwikkelingen in de structuur van de werkgelegenheid Beroep

Opleiding

Bron: ROA 
9. Transport en communicatie 

Tabel 9.1

Kernindicatoren

\section{Arbeidsomstandigheden}

Belastende arbeidsomstandigheden

$\begin{array}{rr}\% & \text { typering } \\ 24 & \text { gemiddeld } \\ 10 & \text { gemiddeld } \\ 38 & \text { gemiddeld } \\ 51 & \text { gemiddeld } \\ 65 & \text { gemiddeld } \\ & \\ 9 & \text { gemiddeld } \\ 7 & \text { hoog }\end{array}$

Lawaai
Trilling
Kracht zetten
Beeldschermwerk
Tijdsdruk
Verzuim vanwege lichamelijke belasting, percentage 1999
Verzuim vanwege de hoge werkdruk, percentage 1999

hoog

\section{Technologische en organisatorische ontwikkelingen}

\begin{tabular}{|c|c|c|c|c|c|c|}
\hline Organisatorische ontwikkelingen & $992-1994^{*}$ & \multicolumn{2}{|c|}{ 1994-1996* } & \multicolumn{2}{|c|}{$1996-1998^{*}$} & $1992-1998^{*}$ \\
\hline Kleine veranderingen & 10 & & 7 & & 9 & 5 \\
\hline Intensieve veranderingen & 24 & & 4 & & 5 & 6 \\
\hline Veranderingen in positie & 3 & & 16 & & 10 & 5 \\
\hline Interne reorganisaties & 38 & & 13 & & 16 & 11 \\
\hline Technologische ontwikkelingen & 1997 & 1998 & 1999 & 2000 & 2001 & 1997-2001* \\
\hline FTE's ICT-personeel & 1,04 & 1,33 & 1,33 & 1,44 & 1,60 & 11 \\
\hline Reële automatiseringskosten (euro) & 215100 & 267100 & 296600 & 312500 & 316600 & 10 \\
\hline Aantal PC's $\mathrm{s}^{\star *}$ & 22 & 24 & 25 & 27 & 29 & 6 \\
\hline Aantal PC's in netwerk ${ }^{* *}$ & 20 & 22 & 23 & 25 & 27 & 7 \\
\hline Aantal internet-PC's** & - & 8 & 9 & 12 & 14 & 19 \\
\hline 1994 & 1995 & 1996 & 1997 & 1998 & 1999 & 1994-1999* \\
\hline Reële R\&D uitgaven & 85 & 79 & 76 & 66 & 97 & 2 \\
\hline
\end{tabular}

Ontwikkelingen in de structuur van de werkgelegenheid

Uitstroomrisico, 1994-1998*

Verwachte uitbreidingsvraag, 2001-2006*

Flexibele arbeid, percentage 2000

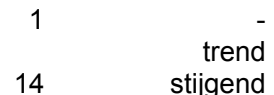

typering gemiddeld

Cursusparticipatie, percentage 1998-2000

Bron: K\&E, POLS, Automatiseringsstatistieken (allen CBS), Arbeidsaanbod- en arbeidsvraagpanel (beiden OSA), POA (ROA)

* Gemiddelde jaarlijkse percentages

** Aantal per bedrijf 


\section{Risicoprofiel}

Figuur 9.1

Sectoraal risicoprofiel

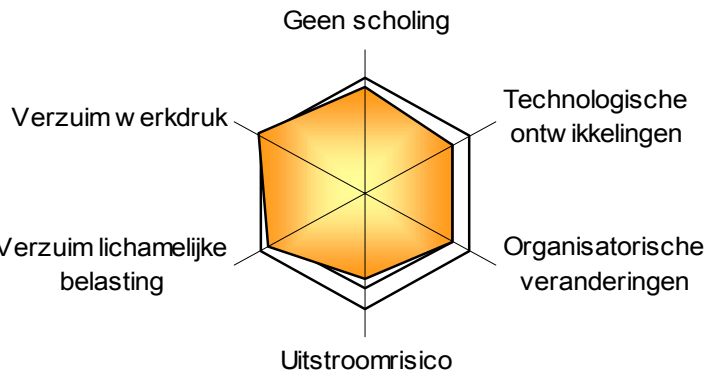

\section{Transport en communicatie}

Uitstroomrisico

\section{Arbeidsomstandigheden}

Tabel 9.2

Percentage werkenden dat wordt geconfronteerd met lawaai tijdens het werk, 2000

\begin{tabular}{|c|c|c|c|}
\hline & $\%$ & typering & trend \\
\hline \multicolumn{4}{|l|}{ Bedrijfsgrootte } \\
\hline 5 tot 10 & - & laag & sterk dalend \\
\hline 10 tot 20 & 14 & laag & dalend \\
\hline 20 tot 100 & 29 & hoog & stijgend \\
\hline \multicolumn{4}{|l|}{ Beroep } \\
\hline Pedagogische beroepen & - & erg laag & - \\
\hline Culturele beroepen & - & erg hoog & - \\
\hline Agrarische beroepen & - & erg hoog & - \\
\hline Technische en Industrieberoepen & 51 & erg hoog & dalend \\
\hline Transportberoepen & 23 & gemiddeld & constant \\
\hline Medische en Paramedische beroepen & - & - & - \\
\hline Economisch-administratieve beroepen & 18 & gemiddeld & sterk stijgend \\
\hline Informaticaberoepen & - & erg laag & - \\
\hline Sociaal-culturele beroepen & - & gemiddeld & - \\
\hline Verzorgende en Dienstverlenende beroepen & - & erg hoog & stijgend \\
\hline Openbare orde- en Veiligheidsberoepen & - & erg hoog & - \\
\hline \multicolumn{4}{|l|}{ Opleiding } \\
\hline Basisonderwijs & 15 & laag & sterk dalend \\
\hline VMBO Theorie & 21 & gemiddeld & stijgend \\
\hline VMBO Landbouw en techniek & 20 & gemiddeld & dalend \\
\hline VMBO Economie & 29 & hoog & sterk stijgend \\
\hline VMBO Verzorging & - & erg hoog & sterk stijgend \\
\hline HAVO/ VWO & 24 & gemiddeld & sterk stijgend \\
\hline MBO Landbouw en techniek & 34 & erg hoog & constant \\
\hline MBO Economie & 15 & laag & constant \\
\hline MBO Dienstverlening en gezondheidszorg & - & gemiddeld & dalend \\
\hline HO Landbouw en techniek & 32 & hoog & constant \\
\hline HO Economie & 36 & erg hoog & sterk stijgend \\
\hline HO Onderwijs en sociaal cultureel & - & hoog & sterk stijgend \\
\hline HO (Para)medisch & - & erg laag & - \\
\hline
\end{tabular}

Bron: EBB (CBS), bewerking ROA 
Tabel 9.3

Percentage werkenden dat gebruik maakt van gereedschap of apparaten die trilling veroorzaken, 2000

\begin{tabular}{|c|c|c|c|}
\hline & $\%$ & typering & trend \\
\hline \multicolumn{4}{|l|}{ Bedrijfsgrootte } \\
\hline 5 tot 10 & - & gemiddeld & stijgend \\
\hline 10 tot 20 & 12 & gemiddeld & stijgend \\
\hline 20 tot 100 & 9 & gemiddeld & constant \\
\hline \multicolumn{4}{|l|}{ Beroep } \\
\hline Pedagogische beroepen & - & laag & - \\
\hline Culturele beroepen & - & laag & - \\
\hline Agrarische beroepen & - & laag & - \\
\hline Technische en Industrieberoepen & 28 & erg hoog & sterk dalend \\
\hline Transportberoepen & 11 & gemiddeld & stijgend \\
\hline Economisch-administratieve beroepen & - & laag & constant \\
\hline Informaticaberoepen & - & laag & - \\
\hline Sociaal-culturele beroepen & - & laag & - \\
\hline Verzorgende en Dienstverlenende beroepen & - & laag & - \\
\hline Openbare orde- en Veiligheidsberoepen & - & gemiddeld & - \\
\hline \multicolumn{4}{|l|}{ Opleiding } \\
\hline Basisonderwijs & 12 & gemiddeld & sterk stijgend \\
\hline VMBO Theorie & - & gemiddeld & sterk stijgend \\
\hline VMBO Landbouw en techniek & 15 & gemiddeld & sterk stijgend \\
\hline VMBO Economie & - & gemiddeld & dalend \\
\hline VMBO Verzorging & - & gemiddeld & - \\
\hline HAVO/ VWO & - & laag & sterk stijgend \\
\hline MBO Landbouw en techniek & 21 & hoog & constant \\
\hline MBO Economie & - & laag & - \\
\hline MBO Dienstverlening en gezondheidszorg & - & laag & - \\
\hline HO Landbouw en techniek & - & gemiddeld & sterk dalend \\
\hline HO Economie & - & laag & - \\
\hline HO Onderwijs en sociaal cultureel & - & laag & - \\
\hline $\mathrm{HO}$ (Para)medisch & - & laag & - \\
\hline
\end{tabular}

Bron: EBB (CBS) 
Tabel 9.4

Percentage werkenden dat kracht moet zetten tijdens het werk, 2000

\begin{tabular}{|c|c|c|c|}
\hline & $\%$ & typering & trend \\
\hline \multicolumn{4}{|l|}{ Bedrijfsgrootte } \\
\hline 5 tot 10 & 38 & gemiddeld & sterk dalend \\
\hline 10 tot 20 & 41 & gemiddeld & dalend \\
\hline 20 tot 100 & 37 & gemiddeld & stijgend \\
\hline 100 tot 500 & - & - & - \\
\hline 500 of meer & - & gemiddeld & - \\
\hline \multicolumn{4}{|l|}{ Beroep } \\
\hline Pedagogische beroepen & - & erg laag & - \\
\hline Culturele beroepen & - & erg laag & - \\
\hline Agrarische beroepen & - & erg hoog & - \\
\hline Technische en Industrieberoepen & 57 & hoog & dalend \\
\hline Transportberoepen & 56 & hoog & constant \\
\hline Medische en Paramedische beroepen & - & - & - \\
\hline Economisch-administratieve beroepen & 13 & laag & sterk stijgend \\
\hline Informaticaberoepen & - & erg laag & - \\
\hline Sociaal-culturele beroepen & - & erg laag & - \\
\hline Verzorgende en Dienstverlenende beroepen & - & gemiddeld & sterk dalend \\
\hline Openbare orde- en Veiligheidsberoepen & - & gemiddeld & - \\
\hline \multicolumn{4}{|l|}{ Opleiding } \\
\hline Basisonderwijs & 52 & hoog & constant \\
\hline VMBO Theorie & 58 & hoog & sterk stijgend \\
\hline VMBO Landbouw en techniek & 55 & hoog & constant \\
\hline VMBO Economie & 44 & gemiddeld & sterk dalend \\
\hline VMBO Verzorging & - & gemiddeld & sterk stijgend \\
\hline HAVO/ VWO & 21 & laag & constant \\
\hline MBO Landbouw en techniek & 44 & gemiddeld & dalend \\
\hline MBO Economie & 28 & gemiddeld & sterk stijgend \\
\hline MBO Dienstverlening en gezondheidszorg & 38 & gemiddeld & stijgend \\
\hline HO Landbouw en techniek & - & laag & constant \\
\hline HO Economie & - & laag & sterk stijgend \\
\hline HO Onderwijs en sociaal cultureel & - & laag & sterk stijgend \\
\hline HO (Para)medisch & - & hoog & - \\
\hline
\end{tabular}

Bron: EBB (CBS) 
Tabel 9.5

Percentage werkenden dat onder hoge tijdsdruk werkt, 2000

\begin{tabular}{|c|c|c|c|}
\hline & $\%$ & typering & trend \\
\hline \multicolumn{4}{|l|}{ Bedrijfsgrootte } \\
\hline 5 tot 10 & 48 & laag & sterk dalend \\
\hline 10 tot 20 & 60 & gemiddeld & constant \\
\hline 20 tot 100 & 68 & hoog & constant \\
\hline 500 of meer & - & erg laag & - \\
\hline \multicolumn{4}{|l|}{ Beroep } \\
\hline Pedagogische beroepen & - & erg hoog & constant \\
\hline Culturele beroepen & - & gemiddeld & - \\
\hline Agrarische beroepen & - & erg laag & - \\
\hline Technische en Industrieberoepen & 66 & hoog & constant \\
\hline Transportberoepen & 63 & gemiddeld & dalend \\
\hline Economisch-administratieve beroepen & 66 & hoog & dalend \\
\hline Informaticaberoepen & 78 & erg hoog & sterk stijgend \\
\hline Sociaal-culturele beroepen & - & laag & sterk stijgend \\
\hline Verzorgende en Dienstverlenende beroepen & - & gemiddeld & sterk dalend \\
\hline Openbare orde- en Veiligheidsberoepen & - & gemiddeld & sterk stijgend \\
\hline \multicolumn{4}{|l|}{ Opleiding } \\
\hline Basisonderwijs & 56 & gemiddeld & constant \\
\hline VMBO Theorie & 62 & gemiddeld & dalend \\
\hline VMBO Landbouw en techniek & 64 & gemiddeld & constant \\
\hline VMBO Economie & 63 & gemiddeld & sterk dalend \\
\hline VMBO Verzorging & - & laag & stijgend \\
\hline HAVO/ VWO & 60 & gemiddeld & sterk stijgend \\
\hline MBO Landbouw en techniek & 66 & hoog & dalend \\
\hline MBO Economie & 62 & gemiddeld & sterk dalend \\
\hline MBO Dienstverlening en gezondheidszorg & 68 & hoog & sterk stijgend \\
\hline HO Landbouw en techniek & 78 & erg hoog & constant \\
\hline HO Economie & 77 & erg hoog & stijgend \\
\hline HO Onderwijs en sociaal cultureel & 73 & erg hoog & sterk stijgend \\
\hline HO (Para)medisch & - & erg hoog & - \\
\hline
\end{tabular}

Bron: EBB (CBS) 
Tabel 9.6

Percentage werkenden dat als gevolg van klachten door lichamelijke belasting het werk heeft verzuimd, 1999

typering

Beroep

Pedagogische beroepen

Technische en Industrieberoepen

Transportberoepen

Economisch-administratieve beroepen

Informaticaberoepen

Verzorgende en Dienstverlenende beroepen

Opleiding

Basisonderwijs

VMBO Theorie

VMBO Landbouw en techniek

VMBO Economie

VMBO Verzorging

HAVO/ VWO

MBO Landbouw en techniek

MBO Economie

MBO Dienstverlening en gezondheidszorg

HO Landbouw en techniek

HO Economie

HO Onderwijs en sociaal culturee

HO (Para)medisch

erg laag

hoog

hoog

gemiddeld

erg laag

erg hoog

erg hoog

hoog

hoog

erg hoog

erg laag

laag

gemiddeld

hoog

erg hoog

erg laag

erg laag

erg laag

erg hoog

Bron: POLS (CBS)

Tabel 9.7

Percentage werkenden dat als gevolg van problemen met de werkdruk het werk heeft verzuimd, 1999

typering

Beroep

Pedagogische beroepen

Technische en Industrieberoepen

Transportberoepen

Economisch-administratieve beroepen

Informaticaberoepen

Verzorgende en Dienstverlenende beroepen

erg laag

erg laag

gemiddeld

erg hoog

erg laag

Opleiding

Basisonderwijs

VMBO Theorie

VMBO Landbouw en techniek

VMBO Economie

VMBO Verzorging

$\mathrm{HAVO} / \mathrm{VWO}$

MBO Landbouw en techniek

MBO Economie

MBO Dienstverlening en gezondheidszorg

HO Landbouw en techniek

HO Economie

HO Onderwijs en sociaal cultureel

erg hoog

laag

gemiddeld

erg laag

erg laag

erg hoog

erg laag

erg hoog

erg laag

erg hoog

erg hoog

erg laag

Bron: POLS (CBS) 
Technologische en organisatorische ontwikkelingen

Tabel 9.8

Informatisering, 2000

\begin{tabular}{|c|c|c|c|}
\hline & $\%$ & typering & trend \\
\hline \multicolumn{4}{|l|}{ Bedrijfsgrootte } \\
\hline 5 tot 10 & 34 & laag & sterk dalend \\
\hline 10 tot 20 & 36 & laag & stijgend \\
\hline 20 tot 100 & 57 & gemiddeld & constant \\
\hline 100 tot 500 & - & erg laag & - \\
\hline 500 of meer & - & laag & - \\
\hline \multicolumn{4}{|l|}{ Beroep } \\
\hline Pedagogische beroepen & - & erg hoog & - \\
\hline Culturele beroepen & - & erg laag & - \\
\hline Agrarische beroepen & - & hoog & - \\
\hline Technische en Industrieberoepen & 50 & gemiddeld & constant \\
\hline Transportberoepen & 16 & erg laag & constant \\
\hline Economisch-administratieve beroepen & 94 & erg hoog & constant \\
\hline Informaticaberoepen & 100 & erg hoog & - \\
\hline Sociaal-culturele beroepen & - & erg hoog & sterk stijgend \\
\hline Verzorgende en Dienstverlenende beroepen & - & erg laag & sterk dalend \\
\hline Openbare orde- en Veiligheidsberoepen & - & erg hoog & sterk stijgend \\
\hline \multicolumn{4}{|l|}{ Opleiding } \\
\hline Basisonderwijs & 18 & erg laag & sterk stijgend \\
\hline VMBO Theorie & 42 & laag & sterk dalend \\
\hline VMBO Landbouw en techniek & 33 & laag & sterk stijgend \\
\hline VMBO Economie & - & erg laag & sterk dalend \\
\hline VMBO Verzorging & - & laag & sterk stijgend \\
\hline HAVO/ VWO & 63 & gemiddeld & sterk stijgend \\
\hline MBO Landbouw en techniek & 52 & gemiddeld & sterk dalend \\
\hline MBO Economie & 73 & hoog & dalend \\
\hline MBO Dienstverlening en gezondheidszorg & 46 & gemiddeld & stijgend \\
\hline HO Landbouw en techniek & 86 & hoog & constant \\
\hline HO Economie & 92 & erg hoog & sterk stijgend \\
\hline HO Onderwijs en sociaal cultureel & 74 & hoog & sterk stijgend \\
\hline $\mathrm{HO}$ (Para)medisch & - & gemiddeld & - \\
\hline
\end{tabular}

Bron: EBB (CBS) 
Ontwikkelingen in de structuur van de werkgelegenheid

Tabel 9.9

Uitstroomrisico, gemiddeld jaarlijks percentage, 1994-1998

$\%$

typering

Beroep

Technische en industrieberoepen

Transportberoepen

Economisch-administratieve beroepen

Informaticaberoepen

Verzorgende en dienstverlenende beroepen

$2,6 \quad$ laag

4,9 gemiddeld

13,3 erg hoog

Opleiding

Basisonderwijs

VMBO theorie

0,0

VMBO overig

$2,4 \quad$ laag

HAVO/NWO

0,0

$2,7 \quad$ gemiddeld

MBO

7,9

4,0

$\mathrm{HBO}$

hoog

gemiddeld

WO

2,8
23,5

gemiddeld

erg hoog

Bron: SEP (CBS)

\section{Scholingsinspanningen}

Tabel 9.10

Deelname aan bedrijfsopleidingen, 2000 (momentopname)

\begin{tabular}{|c|c|c|c|}
\hline & $\%$ & typering & trend \\
\hline \multicolumn{4}{|l|}{ Beroep } \\
\hline Pedagogische beroepen & - & hoog & - \\
\hline Culturele beroepen & - & erg laag & - \\
\hline Agrarische beroepen & - & erg laag & - \\
\hline Technische en Industrieberoepen & - & erg hoog & stijgend \\
\hline Transportberoepen & 4 & erg laag & stijgend \\
\hline Economisch-administratieve beroepen & 8 & hoog & sterk stijgend \\
\hline Informaticaberoepen & - & erg hoog & sterk stijgend \\
\hline Sociaal-culturele beroepen & - & erg hoog & - \\
\hline Verzorgende en Dienstverlenende beroepen & - & hoog & stijgend \\
\hline Openbare orde- en Veiligheidsberoepen & - & erg laag & - \\
\hline \multicolumn{4}{|l|}{ Opleiding } \\
\hline Basisonderwijs & - & erg laag & sterk dalend \\
\hline VMBO Theorie & - & gemiddeld & stijgend \\
\hline VMBO Landbouw en techniek & - & laag & sterk stijgend \\
\hline VMBO Economie & - & erg laag & sterk stijgend \\
\hline VMBO Verzorging & - & erg laag & sterk dalend \\
\hline HAVO/ VWO & - & hoog & sterk stijgend \\
\hline MBO Landbouw en techniek & 9 & erg hoog & stijgend \\
\hline MBO Economie & - & gemiddeld & dalend \\
\hline MBO Dienstverlening en gezondheidszorg & - & laag & sterk stijgend \\
\hline HO Landbouw en techniek & - & gemiddeld & sterk stijgend \\
\hline HO Economie & - & hoog & sterk stijgend \\
\hline HO Onderwijs en sociaal cultureel & - & erg hoog & \\
\hline $\mathrm{HO}$ (Para)medisch & - & erg laag & - \\
\hline
\end{tabular}

Bron: EBB (CBS) 


\section{Doelgroepen voor scholingsbeleid}

Tabel 9.11

Risicogroepen binnen de sector per risicofactor

Lichamelijke belasting

Beroep

Verzorgende en dienstverlenende beroepen

Opleiding

Psychische belasting

Beroep

Opleiding

Informatisering

Beroep

Opleiding

Ontwikkelingen in de structuur van de werkgelegenheid Beroep

Opleiding

Bron: ROA 

10. Bank- en verzekeringswezen 

Tabel 10.1

Kernindicatoren

\section{Arbeidsomstandigheden}

Belastende arbeidsomstandigheden

Lawaai

Trilling

Kracht zetten

Beeldschermwerk

Tijdsdruk

typering

Verzuim vanwege lichamelijke belasting, percentage 1999

Verzuim vanwege de hoge werkdruk, percentage 1999

$\begin{array}{rr}\% & \text { typering } \\ 6 & \text { erg laag } \\ 1 & \text { laag } \\ 3 & \text { erg laag } \\ 98 & \text { erg hoog } \\ 64 & \text { gemiddeld } \\ & \\ 6 & \text { gemiddeld } \\ 8 & \text { erg hoog }\end{array}$

Technologische en organisatorische ontwikkelingen

Organisatorische ontwikkelingen

$1992-1994^{*}$

$1994-1996^{*}$

$1996-1998^{\star}$

$1992-1998$

Kleine veranderingen

Intensieve veranderingen

Veranderingen in positie

Interne reorganisaties

$11 \quad 18$

$9 \quad 5$

Technologische ontwikkelingen

10

5
9
33

17

6

8
28

FTE's ICT-personeel

$\begin{array}{lllll}1997 & 1998 & 1999 & 2000 & 2001\end{array}$

erg hoog

Reële automatiseringskosten (euro)

$8,11 \quad 7,77 \quad 8,16 \quad 8,40 \quad 8,57$

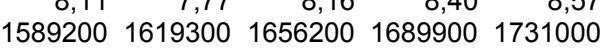

$1997-2001^{*}$

Aantal PC's**

Aantal PC's in netwerk ${ }^{* *}$

Aantal internet-PC's**

$\begin{array}{lllll}116 & 103 & 109 & 115 & 118\end{array}$

$\begin{array}{lllll}108 & 93 & 102 & 107 & 110\end{array}$

(verandering 1998-2001)

$\begin{array}{rrrrrrr} & 116 & 103 & 109 & 115 & 118 & 0 \\ & 108 & 93 & 102 & 107 & 110 & 0 \\ & - & 20 & 22 & 30 & 43 & 29 \\ 1994 & & & & & & \\ & 1995 & 1996 & 1997 & 1998 & 1999 & 1994-1999^{*} \\ 9 & 8 & 60 & 82 & 96 & 92 & 16\end{array}$

Ontwikkelingen in de structuur van de werkgelegenheid

Uitstroomrisico, 1994-1998*

Verwachte uitbreidingsvraag, 2001-2006*

Flexibele arbeid, percentage 2000
6
trend
dalend

\section{Scholingsdeelname}

Deelname aan bedrijfsopleidingen, percentage 2000 (momentopname)

Cursusparticipatie, percentage 1998-2000

66

Bron: K\&E, POLS, Automatiseringsstatistieken (allen CBS), Arbeidsaanbod- en arbeidsvraagpanel (beiden OSA), POA (ROA)

* Gemiddelde jaarlijkse percentages

** Aantal per bedrijf 


\section{Risicoprofiel}

Figuur 10.1

Sectoraal risicoprofiel

Bank- en verzekeringswezen

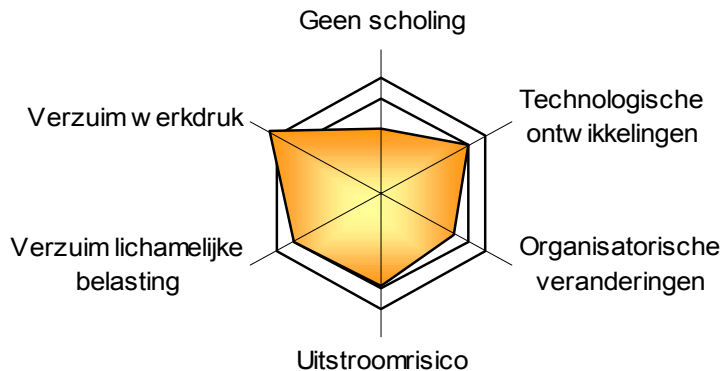

\section{Arbeidsomstandigheden}

Tabel 10.2

Percentage werkenden dat wordt geconfronteerd met lawaai tijdens het werk, 2000

\begin{tabular}{|c|c|c|c|}
\hline & $\%$ & typering & trend \\
\hline \multicolumn{4}{|l|}{ Bedrijfsgrootte } \\
\hline 10 tot 20 & - & erg laag & sterk stijgend \\
\hline 20 tot 100 & 7 & erg laag & sterk stijgend \\
\hline \multicolumn{4}{|l|}{ Beroep } \\
\hline Pedagogische beroepen & - & erg laag & - \\
\hline Culturele beroepen & - & erg laag & - \\
\hline Technische en Industrieberoepen & - & erg laag & - \\
\hline Transportberoepen & - & erg laag & - \\
\hline Medische en Paramedische beroepen & - & erg laag & - \\
\hline Economisch-administratieve beroepen & 7 & erg laag & sterk stijgend \\
\hline Informaticaberoepen & - & erg laag & - \\
\hline Sociaal-culturele beroepen & - & erg laag & - \\
\hline Verzorgende en Dienstverlenende beroepen & - & erg laag & - \\
\hline Openbare orde- en Veiligheidsberoepen & - & erg laag & - \\
\hline \multicolumn{4}{|l|}{ Opleiding } \\
\hline Basisonderwijs & - & gemiddeld & - \\
\hline VMBO Theorie & - & erg laag & dalend \\
\hline VMBO Landbouw en techniek & - & erg laag & - \\
\hline HAVO/ VWO & - & laag & constant \\
\hline MBO Landbouw en techniek & - & erg laag & - \\
\hline MBO Economie & - & erg laag & sterk stijgend \\
\hline MBO Dienstverlening en gezondheidszorg & - & laag & sterk stijgend \\
\hline HO Landbouw en techniek & - & erg laag & - \\
\hline HO Economie & - & erg laag & - \\
\hline HO Onderwijs en sociaal cultureel & - & erg laag & constant \\
\hline HO (Para)medisch & - & erg laag & - \\
\hline
\end{tabular}

Bron: EBB (CBS), bewerking ROA 
Tabel 10.3

Percentage werkenden dat gebruik maakt van gereedschap of apparaten die trilling veroorzaken, 2000

\begin{tabular}{|c|c|c|c|}
\hline & $\%$ & typering & trend \\
\hline \multicolumn{4}{|l|}{ Bedrijfsgrootte } \\
\hline 20 tot 100 & - & - & sterk stijgend \\
\hline \multicolumn{4}{|l|}{ Beroep } \\
\hline Pedagogische beroepen & - & laag & - \\
\hline Culturele beroepen & - & laag & - \\
\hline Technische en Industrieberoepen & - & laag & - \\
\hline Transportberoepen & - & laag & - \\
\hline Medische en Paramedische beroepen & - & laag & - \\
\hline Economisch-administratieve beroepen & - & laag & - \\
\hline Informaticaberoepen & - & laag & - \\
\hline Sociaal-culturele beroepen & - & laag & - \\
\hline Verzorgende en Dienstverlenende beroepen & - & laag & - \\
\hline Openbare orde- en Veiligheidsberoepen & - & laag & - \\
\hline \multicolumn{4}{|l|}{ Opleiding } \\
\hline Basisonderwijs & - & laag & - \\
\hline VMBO Theorie & - & laag & - \\
\hline VMBO Landbouw en techniek & - & laag & - \\
\hline HAVO/ VWO & - & laag & - \\
\hline MBO Landbouw en techniek & - & hoog & - \\
\hline MBO Economie & - & laag & - \\
\hline MBO Dienstverlening en gezondheidszorg & - & laag & - \\
\hline HO Landbouw en techniek & - & laag & - \\
\hline HO Economie & - & laag & - \\
\hline HO Onderwijs en sociaal cultureel & - & laag & - \\
\hline HO (Para)medisch & - & laag & - \\
\hline
\end{tabular}

Bron: EBB (CBS) 
Tabel 10.4

Percentage werkenden dat kracht moet zetten tijdens het werk, 2000

\begin{tabular}{|c|c|c|c|}
\hline & $\%$ & typering & trend \\
\hline \multicolumn{4}{|l|}{ Bedrijfsgrootte } \\
\hline 10 tot 20 & - & - & sterk stijgend \\
\hline 20 tot 100 & 4 & erg laag & stijgend \\
\hline \multicolumn{4}{|l|}{ Beroep } \\
\hline Pedagogische beroepen & - & erg laag & - \\
\hline Culturele beroepen & - & erg laag & - \\
\hline Technische en Industrieberoepen & - & erg laag & - \\
\hline Transportberoepen & - & gemiddeld & - \\
\hline Medische en Paramedische beroepen & - & erg laag & - \\
\hline Economisch-administratieve beroepen & 3 & erg laag & sterk stijgend \\
\hline Informaticaberoepen & - & erg laag & sterk stijgend \\
\hline Sociaal-culturele beroepen & - & erg laag & - \\
\hline Verzorgende en Dienstverlenende beroepen & - & gemiddeld & sterk dalend \\
\hline Openbare orde- en Veiligheidsberoepen & - & erg laag & - \\
\hline \multicolumn{4}{|l|}{ Opleiding } \\
\hline Basisonderwijs & - & laag & - \\
\hline VMBO Theorie & - & erg laag & stijgend \\
\hline VMBO Landbouw en techniek & - & erg laag & - \\
\hline HAVO/ VWO & - & erg laag & - \\
\hline MBO Landbouw en techniek & - & erg laag & - \\
\hline MBO Economie & - & erg laag & sterk stijgend \\
\hline MBO Dienstverlening en gezondheidszorg & - & erg laag & constant \\
\hline HO Landbouw en techniek & - & erg laag & - \\
\hline HO Economie & - & erg laag & - \\
\hline HO Onderwijs en sociaal cultureel & - & erg laag & - \\
\hline HO (Para)medisch & - & erg laag & - \\
\hline
\end{tabular}

Bron: EBB (CBS) 
Tabel 10.5

Percentage werkenden dat onder hoge tijdsdruk werkt, 2000

$\% \quad$ typering trend

Bedrijfsgrootte

5 tot 10

10 tot 20

20 tot 100

$\begin{array}{lll}46 & \text { erg laag } & \text { sterk stijgend } \\ 56 & \text { gemiddeld } & \text { dalend } \\ 68 & \text { hoog } & \text { constant }\end{array}$

Beroep

Pedagogische beroepen

Culturele beroepen

Technische en Industrieberoepen

Transportberoepen

Medische en Paramedische beroepen

Economisch-administratieve beroepen

Informaticaberoepen

Sociaal-culturele beroepen

Verzorgende en Dienstverlenende beroepen

Openbare orde- en Veiligheidsberoepen

Opleiding

Basisonderwijs

VMBO Theorie

VMBO Landbouw en techniek

VMBO Economie

VMBO Verzorging

HAVO/ VWO

MBO Landbouw en techniek

MBO Economie

MBO Dienstverlening en gezondheidszorg

HO Landbouw en techniek

HO Economie

$\mathrm{HO}$ Onderwijs en sociaal cultureel

HO (Para)medisch

$\begin{array}{rll}- & \text { erg hoog } & \text { sterk dalend } \\ - & \text { erg laag } & \text { dalend } \\ - & \text { erg hoog } & \text { dalend } \\ - & \text { erg laag } & - \\ - & \text { gemiddeld } & \text { stijgend } \\ 63 & \text { gemiddeld } & \text { constant } \\ 75 & \text { erg hoog } & \text { stijgend } \\ - & \text { erg hoog } & \text { sterk stijgend } \\ - & \text { laag } & \text { sterk dalend } \\ - & \text { gemiddeld } & - \\ & & \\ & & \\ 59 & \text { hoog } & \text { sterk stijgend } \\ - & \text { hoog } & \text { dalend } \\ - & \text { erg laag } & - \\ - & \text { laag } & \text { sterk dalend } \\ 63 & \text { gemiddeld } & \text { dalend } \\ - & \text { gemiddeld } & \text { constant } \\ 55 & \text { gemiddeld } & \text { constant } \\ 57 & \text { gemiddeld } & \text { sterk dalend } \\ 80 & \text { erg hoog } & \text { dalend } \\ 76 & \text { erg hoog } & \text { sterk stijgend } \\ 64 & \text { gemiddeld } & \text { sterk dalend } \\ - & \text { hoog } & \text { sterk stijgend }\end{array}$

Bron: EBB (CBS) 
Tabel 10.6

Percentage werkenden dat als gevolg van klachten door lichamelijke belasting het werk heeft verzuimd, 1999

typering

Beroep

Culturele beroepen

Technische en Industrieberoepen

Medische en Paramedische beroepen

Economisch-administratieve beroepen

Informaticaberoepen

Sociaal-culturele beroepen

Opleiding

Basisonderwijs

VMBO Theorie

VMBO Landbouw en techniek

VMBO Economie

VMBO Verzorging

$\mathrm{HAVO} / \mathrm{VWO}$

MBO Landbouw en techniek

MBO Economie

MBO Dienstverlening en gezondheidszorg

HO Landbouw en techniek

HO Economie

HO Onderwijs en sociaal culturee

HO (Para)medisch

- $\quad$ erg laag

- $\quad$ erg laag

- $\quad$ erg laag

8 gemiddeld

- $\quad$ erg laag

- $\quad$ erg laag

- $\quad$ erg laag

23 erg hoog

- $\quad$ erg laag

- $\quad$ erg hoog

- $\quad$ erg laag

8 gemiddeld

100 erg hoog

2 laag

$4 \quad$ laag

- $\quad$ erg laag

- $\quad$ erg laag

- $\quad$ erg laag

- $\quad$ erg laag

Bron: POLS (CBS)

Tabel 10.7

Percentage werkenden dat als gevolg van problemen met de werkdruk het werk heeft verzuimd, 1999

typering

\section{Beroep}

Culturele beroepen

Technische en Industrieberoepen

Medische en Paramedische beroepen

Economisch-administratieve beroepen

Informaticaberoepen

Sociaal-culturele beroepen

erg laag

- $\quad$ erg laag

- $\quad$ erg laag

erg hoog

erg laag

Opleiding

Basisonderwijs

VMBO Theorie

VMBO Landbouw en techniek

- $\quad$ erg laag

VMBO Verzorging

HAVO/ VWO

MBO Landbouw en techniek

MBO Economie

MBO Dienstverlening en gezondheidszorg

HO Landbouw en techniek

HO Economie

$\mathrm{HO}$ Onderwijs en sociaal cultureel

HO (Para)medisch

erg hoog

erg hoog

erg laag

erg laag

erg hoog

erg laag

erg laag

erg hoog

erg laag

laag

erg laag

erg laag

Bron: POLS (CBS) 
Technologische en organisatorische ontwikkelingen

Tabel 10.8

Informatisering, 2000

\begin{tabular}{|c|c|c|c|}
\hline & $\%$ & typering & trend \\
\hline \multicolumn{4}{|l|}{ Bedrijfsgrootte } \\
\hline 5 tot 10 & 95 & erg hoog & sterk stijgend \\
\hline 10 tot 20 & 98 & erg hoog & sterk stijgend \\
\hline 20 tot 100 & 98 & erg hoog & constant \\
\hline 500 of meer & - & gemiddeld & - \\
\hline \multicolumn{4}{|l|}{ Beroep } \\
\hline Pedagogische beroepen & - & erg hoog & - \\
\hline Culturele beroepen & - & erg hoog & - \\
\hline Technische en Industrieberoepen & - & laag & - \\
\hline Transportberoepen & - & gemiddeld & - \\
\hline Medische en Paramedische beroepen & - & erg hoog & - \\
\hline Economisch-administratieve beroepen & 98 & erg hoog & stijgend \\
\hline Informaticaberoepen & 100 & erg hoog & sterk stijgend \\
\hline Sociaal-culturele beroepen & - & erg hoog & - \\
\hline Verzorgende en Dienstverlenende beroepen & - & erg laag & - \\
\hline Openbare orde- en Veiligheidsberoepen & - & erg hoog & - \\
\hline \multicolumn{4}{|l|}{ Opleiding } \\
\hline Basisonderwijs & - & hoog & - \\
\hline VMBO Theorie & 98 & erg hoog & constant \\
\hline VMBO Landbouw en techniek & 99 & erg hoog & dalend \\
\hline HAVO/ VWO & 95 & erg hoog & dalend \\
\hline MBO Landbouw en techniek & 90 & hoog & stijgend \\
\hline MBO Economie & 99 & erg hoog & stijgend \\
\hline MBO Dienstverlening en gezondheidszorg & 99 & erg hoog & dalend \\
\hline HO Landbouw en techniek & 98 & erg hoog & - \\
\hline HO Economie & 99 & erg hoog & sterk stijgend \\
\hline HO Onderwijs en sociaal cultureel & 97 & erg hoog & sterk stijgend \\
\hline HO (Para)medisch & - & erg hoog & - \\
\hline
\end{tabular}

Bron: EBB (CBS) 
Ontwikkelingen in de structuur van de werkgelegenheid

Tabel 10.9

Uitstroomrisico, gemiddeld jaarlijks percentage, 1994-1998

$\%$

typering

Beroep

Economisch-administratieve beroepen

gemiddeld

Informaticaberoepen

Sociaal-culturele beroepen

Verzorgende en dienstverlenende beroepen

3,6

0,0

14,3

$11,1 \quad$ erg hoog

Opleiding

Basisonderwijs

0,0

VMBO theorie

$5,3 \quad$ gemiddeld

VMBO overig

5,6

HAVO/VWO

4,3

$\mathrm{MBO}$

4,1

$\mathrm{HBO}$

1,1

gemiddeld

gemiddeld

gemiddeld

WO

laag

4,5 gemiddeld

Bron: SEP (CBS)

\section{Scholingsinspanningen}

Tabel 10.10

Deelname aan bedrijfsopleidingen, 2000 (momentopname)

$\% \quad$ typering trend

\section{Beroep}

Pedagogische beroepen

Culturele beroepen

Technische en Industrieberoepen

Transportberoepen

Medische en Paramedische beroepen

Economisch-administratieve beroepen

Informaticaberoepen

Sociaal-culturele beroepen

Verzorgende en Dienstverlenende beroepen

Openbare orde- en Veiligheidsberoepen

Opleiding

Basisonderwijs

VMBO Theorie

VMBO Landbouw en techniek

VMBO Economie

VMBO Verzorging

HAVO/ VWO

MBO Landbouw en techniek

MBO Economie

MBO Dienstverlening en gezondheidszorg

HO Landbouw en techniek

HO Economie

$\mathrm{HO}$ Onderwijs en sociaal cultureel

HO (Para)medisch

\begin{tabular}{rll}
- & erg laag & - \\
- & erg hoog & - \\
- & erg laag & - \\
- & erg laag & - \\
- & erg laag & - \\
13 & erg hoog & dalend \\
- & erg hoog & sterk stijgend \\
- & gemiddeld & - \\
- & erg laag & - \\
- & erg laag & - \\
& & \\
& & \\
- & erg hoog & sterk stijgend \\
- & erg hoog & constant \\
- & laag & sterk dalend \\
- & erg laag & - \\
\hline- & gemiddeld & sterk dalend \\
17 & erg hoog & stijgend \\
- & erg hoog & sterk stijgend \\
11 & erg hoog & sterk dalend \\
14 & erg hoog & stijgend \\
- & gemiddeld & sterk dalend \\
11 & erg hoog & dalend \\
- & erg hoog & sterk stijgend \\
- & erg laag & -
\end{tabular}

Bron: EBB (CBS) 


\section{Doelgroepen voor scholingsbeleid}

Tabel 10.11

Risicogroepen binnen de sector per risicofactor

Lichamelijke belasting

Beroep

Opleiding

Psychische belasting

Beroep

Opleiding

Informatisering

Beroep

Opleiding

Ontwikkelingen in de structuur van de werkgelegenheid Beroep

Opleiding

Bron: ROA 

11. Horeca en zakelijke dienstverlening 

Tabel 11.1

Kernindicatoren

\section{Arbeidsomstandigheden}

Belastende arbeidsomstandigheden

$\begin{array}{rr}\% & \text { typering } \\ & \\ 15 & \text { laag } \\ 6 & \text { laag } \\ 24 & \text { laag } \\ 70 & \text { gemiddeld } \\ 64 & \text { gemiddeld } \\ & \\ 5 & \text { gemiddeld } \\ 4 & \text { gemiddeld }\end{array}$

\section{Technologische en organisatorische ontwikkelingen}

Organisatorische ontwikkelingen

$1992-1994^{*}$

1994-1996*

$1996-1998$

$1992-1998$

Kleine veranderingen

Intensieve veranderingen

Veranderingen in positie

Interne reorganisaties

$37 \quad 11$

$19-10$

932

Technologische ontwikkelingen

65

11
10
32

$65-21$

FTE's ICT-personeel

19981999

2000

$1997-2001$

Reële automatiseringskosten (euro)

$\begin{array}{rrrrr}1,33 & 2,12 & 2,33 & 2,53 & 2,78 \\ 90900 & 136200 & 140900 & 148300 & 156700\end{array}$

15

Aantal PC's**

Aantal PC's in netwerk**

Aantal internet-PC's ${ }^{* *}$

$\begin{array}{llllll}12 & 16 & 17 & 18 & 20 & 12\end{array}$

$\begin{array}{lllll}11 & 15 & 14 & 16 & 17\end{array}$

(verandering 1998-2001)

$\begin{array}{rrrrrrr} & 12 & 16 & 17 & 18 & 20 & 12 \\ & 11 & 15 & 14 & 16 & 17 & 13 \\ & - & 8 & 8 & 11 & 12 & 17 \\ 1994 & & & & & & \\ 1995 & 1996 & 1997 & 1998 & 1999 & 1994-1999^{*} \\ 120 & 124 & 228 & 318 & 236 & 256 & 16\end{array}$

Ontwikkelingen in de structuur van de werkgelegenheid

Uitstroomrisico, 1994-1998*

Verwachte uitbreidingsvraag, 2001-2006*

2,7

Flexibele arbeid, percentage 2000

\section{Scholingsdeelname}

Deelname aan bedrijfsopleidingen, percentage 2000 (momentopname)

typering 6 gemiddeld

Cursusparticipatie, percentage 1998-2000 50

Bron: K\&E, POLS, Automatiseringsstatistieken (allen CBS), Arbeidsaanbod- en arbeidsvraagpanel (beiden OSA), POA (ROA)

* Gemiddelde jaarlijkse percentages

** Aantal per bedrijf 


\section{Risicoprofiel}

Figuur 11.1

Sectoraal risicoprofiel

Horeca en zakelijke dienstverlening

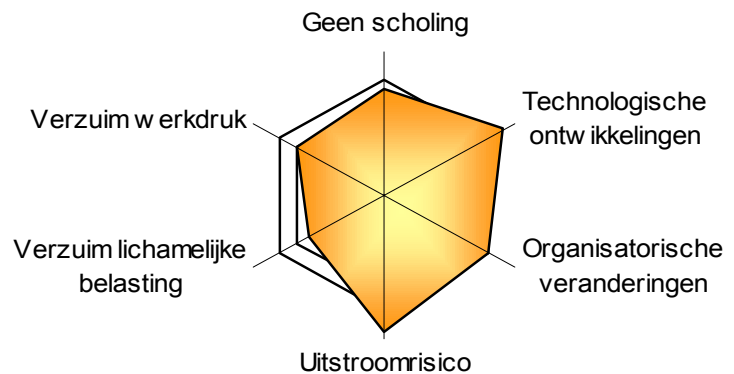

\section{Arbeidsomstandigheden}

Tabel 11.2

Percentage werkenden dat wordt geconfronteerd met lawaai tijdens het werk, 2000

\begin{tabular}{|c|c|c|c|}
\hline & $\%$ & typering & trend \\
\hline \multicolumn{4}{|l|}{ Bedrijfsgrootte } \\
\hline 5 tot 10 & 18 & gemiddeld & sterk stijgend \\
\hline 10 tot 20 & 13 & laag & stijgend \\
\hline 20 tot 100 & 14 & laag & stijgend \\
\hline 500 of meer & - & gemiddeld & - \\
\hline \multicolumn{4}{|l|}{ Beroep } \\
\hline Pedagogische beroepen & - & erg hoog & stijgend \\
\hline Culturele beroepen & - & laag & sterk stijgend \\
\hline Agrarische beroepen & - & gemiddeld & sterk dalend \\
\hline Technische en Industrieberoepen & 21 & gemiddeld & sterk dalend \\
\hline Transportberoepen & - & gemiddeld & sterk dalend \\
\hline Medische en Paramedische beroepen & - & laag & - \\
\hline Economisch-administratieve beroepen & 8 & erg laag & sterk stijgend \\
\hline Informaticaberoepen & 5 & erg laag & sterk stijgend \\
\hline Sociaal-culturele beroepen & - & erg laag & stijgend \\
\hline Verzorgende en Dienstverlenende beroepen & 25 & gemiddeld & sterk stijgend \\
\hline Openbare orde- en Veiligheidsberoepen & - & laag & dalend \\
\hline \multicolumn{4}{|l|}{ Opleiding } \\
\hline Basisonderwijs & 26 & hoog & sterk stijgend \\
\hline VMBO Theorie & 16 & gemiddeld & dalend \\
\hline VMBO Landbouw en techniek & 34 & erg hoog & sterk stijgend \\
\hline VMBO Economie & - & hoog & constant \\
\hline VMBO Verzorging & - & laag & sterk dalend \\
\hline HAVO/VWO & 16 & gemiddeld & sterk stijgend \\
\hline MBO Landbouw en techniek & 15 & laag & sterk dalend \\
\hline MBO Economie & 11 & laag & sterk stijgend \\
\hline MBO Dienstverlening en gezondheidszorg & 21 & gemiddeld & stijgend \\
\hline HO Landbouw en techniek & - & erg laag & sterk dalend \\
\hline HO Economie & - & erg laag & sterk stijgend \\
\hline HO Onderwijs en sociaal cultureel & 12 & laag & sterk stijgend \\
\hline HO (Para)medisch & - & gemiddeld & - \\
\hline
\end{tabular}

Bron: EBB (CBS), bewerking ROA 
Tabel 11.3

Percentage werkenden dat gebruik maakt van gereedschap of apparaten die trilling veroorzaken, 2000

\begin{tabular}{|c|c|c|c|}
\hline & $\%$ & typering & trend \\
\hline \multicolumn{4}{|l|}{ Bedrijfsgrootte } \\
\hline 5 tot 10 & 6 & laag & dalend \\
\hline 10 tot 20 & 7 & laag & sterk stijgend \\
\hline 20 tot 100 & 6 & laag & constant \\
\hline \multicolumn{4}{|l|}{ Beroep } \\
\hline Pedagogische beroepen & - & laag & - \\
\hline Culturele beroepen & - & laag & - \\
\hline Agrarische beroepen & 41 & erg hoog & sterk stijgend \\
\hline Technische en Industrieberoepen & 22 & hoog & stijgend \\
\hline Transportberoepen & - & gemiddeld & sterk dalend \\
\hline Medische en Paramedische beroepen & - & laag & - \\
\hline Economisch-administratieve beroepen & 2 & laag & sterk stijgend \\
\hline Informaticaberoepen & - & laag & sterk dalend \\
\hline Sociaal-culturele beroepen & - & laag & - \\
\hline Verzorgende en Dienstverlenende beroepen & 6 & laag & dalend \\
\hline Openbare orde- en Veiligheidsberoepen & - & laag & - \\
\hline \multicolumn{4}{|l|}{ Opleiding } \\
\hline Basisonderwijs & 14 & gemiddeld & sterk stijgend \\
\hline VMBO Theorie & - & laag & dalend \\
\hline VMBO Landbouw en techniek & 23 & hoog & stijgend \\
\hline VMBO Economie & - & gemiddeld & - \\
\hline VMBO Verzorging & - & gemiddeld & sterk stijgend \\
\hline HAVO/ VWO & - & laag & sterk stijgend \\
\hline MBO Landbouw en techniek & 13 & gemiddeld & constant \\
\hline MBO Economie & - & laag & dalend \\
\hline MBO Dienstverlening en gezondheidszorg & 9 & gemiddeld & stijgend \\
\hline HO Landbouw en techniek & - & laag & sterk dalend \\
\hline HO Economie & - & laag & - \\
\hline HO Onderwijs en sociaal cultureel & - & laag & - \\
\hline $\mathrm{HO}$ (Para)medisch & - & laag & - \\
\hline
\end{tabular}

Bron: EBB (CBS) 
Tabel 11.4

Percentage werkenden dat kracht moet zetten tijdens het werk, 2000

\begin{tabular}{|c|c|c|c|}
\hline & $\%$ & typering & trend \\
\hline \multicolumn{4}{|l|}{ Bedrijfsgrootte } \\
\hline 5 tot 10 & 27 & gemiddeld & constant \\
\hline 10 tot 20 & 25 & laag & sterk stijgend \\
\hline 20 tot 100 & 20 & laag & dalend \\
\hline 500 of meer & 55 & hoog & - \\
\hline \multicolumn{4}{|l|}{ Beroep } \\
\hline Pedagogische beroepen & - & erg laag & sterk dalend \\
\hline Culturele beroepen & 27 & gemiddeld & sterk stijgend \\
\hline Agrarische beroepen & 58 & hoog & stijgend \\
\hline Technische en Industrieberoepen & 34 & gemiddeld & constant \\
\hline Transportberoepen & 76 & erg hoog & sterk stijgend \\
\hline Medische en Paramedische beroepen & - & erg laag & - \\
\hline Economisch-administratieve beroepen & 6 & erg laag & dalend \\
\hline Informaticaberoepen & 8 & erg laag & sterk stijgend \\
\hline Sociaal-culturele beroepen & - & erg laag & - \\
\hline Verzorgende en Dienstverlenende beroepen & 47 & hoog & constant \\
\hline Openbare orde- en Veiligheidsberoepen & - & laag & sterk stijgend \\
\hline \multicolumn{4}{|l|}{ Opleiding } \\
\hline Basisonderwijs & 54 & hoog & sterk stijgend \\
\hline VMBO Theorie & 25 & laag & sterk dalend \\
\hline VMBO Landbouw en techniek & 58 & hoog & constant \\
\hline VMBO Economie & & gemiddeld & dalend \\
\hline VMBO Verzorging & 39 & gemiddeld & constant \\
\hline HAVO/ VWO & 22 & laag & sterk stijgend \\
\hline MBO Landbouw en techniek & 33 & gemiddeld & sterk stijgend \\
\hline MBO Economie & 13 & laag & constant \\
\hline MBO Dienstverlening en gezondheidszorg & 33 & gemiddeld & constant \\
\hline HO Landbouw en techniek & 7 & erg laag & stijgend \\
\hline HO Economie & 4 & erg laag & sterk stijgend \\
\hline HO Onderwijs en sociaal cultureel & 8 & erg laag & sterk dalend \\
\hline $\mathrm{HO}$ (Para)medisch & - & laag & sterk dalend \\
\hline
\end{tabular}

Bron: EBB (CBS) 
Tabel 11.5

Percentage werkenden dat onder hoge tijdsdruk werkt, 2000

$\% \quad$ typering trend

Bedrijfsgrootte

5 tot 10

10 tot 20

20 tot 100

500 of meer

$\begin{array}{lll}58 & \text { gemiddeld } & \text { constant } \\ 63 & \text { gemiddeld } & \text { stijgend } \\ 68 & \text { hoog } & \text { constant } \\ 47 & \text { erg laag } & -\end{array}$

Beroep

Pedagogische beroepen

Culturele beroepen

Agrarische beroepen

Technische en Industrieberoepen

Transportberoepen

Medische en Paramedische beroepen

Economisch-administratieve beroepen

Informaticaberoepen

Sociaal-culturele beroepen

Verzorgende en Dienstverlenende beroepen

Openbare orde- en Veiligheidsberoepen

$\begin{array}{lll}47 & \text { laag } & \text { sterk stijgend } \\ 71 & \text { hoog } & \text { stijgend } \\ 6 & \text { erg laag } & \text { constant } \\ 1 & \text { gemiddeld } & \text { dalend } \\ 50 & \text { laag } & \text { sterk stijgend } \\ - & \text { laag } & \text { sterk stijgend } \\ 6 & \text { hoog } & \text { constant } \\ 6 & \text { erg hoog } & \text { stijgend } \\ 7 & \text { erg hoog } & \text { constant } \\ 9 & \text { gemiddeld } & \text { constant } \\ 4 & \text { erg laag } & \text { sterk stijgend }\end{array}$

Opleiding

Basisonderwijs

VMBO Theorie

VMBO Landbouw en techniek

VMBO Economie

VMBO Verzorging

HAVO/ VWO

MBO Landbouw en techniek

MBO Economie

MBO Dienstverlening en gezondheidszorg

$\mathrm{HO}$ Landbouw en techniek

HO Economie

$\mathrm{HO}$ Onderwijs en sociaal cultureel

HO (Para)medisch

$\begin{array}{ll}\text { laag } & \text { sterk stijgend } \\ \text { gemiddeld } & \text { constant } \\ \text { erg laag } & \text { dalend } \\ \text { gemiddeld } & \text { stijgend } \\ \text { gemiddeld } & \text { sterk stijgend } \\ \text { gemiddeld } & \text { sterk stijgend } \\ \text { laag } & \text { dalend } \\ \text { gemiddeld } & \text { constant } \\ \text { gemiddeld } & \text { constant } \\ \text { erg hoog } & \text { dalend } \\ \text { erg hoog } & \text { stijgend } \\ \text { erg hoog } & \text { stijgend } \\ \text { hoog } & \text { stijgend }\end{array}$

Bron: EBB (CBS) 
Tabel 11.6

Percentage werkenden dat als gevolg van klachten door lichamelijke belasting het werk heeft verzuimd, 1999

$\%$

typering

Beroep

Pedagogische beroepen

Culturele beroepen

Agrarische beroepen

Technische en Industrieberoepen

Transportberoepen

Medische en Paramedische beroepen

Economisch-administratieve beroepen

Informaticaberoepen

Sociaal-culturele beroepen

Verzorgende en Dienstverlenende beroepen

Openbare orde- en Veiligheidsberoepen

erg hoog

gemiddeld

erg hoog

laag

hoog

erg laag

laag

laag

gemiddeld

gemiddeld

erg laag

Opleiding

Basisonderwijs

VMBO Theorie

VMBO Landbouw en techniek

VMBO Economie

VMBO Verzorging

HAVO/ VWO

MBO Landbouw en techniek

MBO Economie

MBO Dienstverlening en gezondheidszorg

HO Landbouw en techniek

HO Economie

HO Onderwijs en sociaal cultureel

HO (Para)medisch

erg hoog

laag

erg hoog

erg laag

gemiddeld

gemiddeld

laag

laag

laag

laag

erg laag

laag

erg laag

Bron: POLS (CBS) 
Tabel 11.7

Percentage werkenden dat als gevolg van problemen met de werkdruk het werk heeft verzuimd, 1999

$\% \quad$ typering

Beroep

Pedagogische beroepen

Culturele beroepen

Agrarische beroepen

Technische en Industrieberoepen

Transportberoepen

Medische en Paramedische beroepen

Economisch-administratieve beroepen

Informaticaberoepen

Sociaal-culturele beroepen

Verzorgende en Dienstverlenende beroepen

Openbare orde- en Veiligheidsberoepen

erg laag

7 hoog

7 hoog

- $\quad$ erg laag

11 erg hoog

erg laag

gemiddeld

erg laag

gemiddeld

gemiddeld

hoog

Opleiding

Basisonderwijs

VMBO Theorie

VMBO Landbouw en techniek

VMBO Economie

VMBO Verzorging

HAVO/ VWO

MBO Landbouw en techniek

MBO Economie

MBO Dienstverlening en gezondheidszorg

HO Landbouw en techniek

HO Economie

HO Onderwijs en sociaal cultureel

$\mathrm{HO}$ (Para)medisch

hoog

gemiddeld

erg hoog

erg laag

laag

erg laag

erg laag

laag

laag

erg laag

laag

hoog

erg laag

Bron: POLS (CBS) 
Technologische en organisatorische ontwikkelingen

Tabel 11.8

Informatisering, 2000

\begin{tabular}{|c|c|c|c|}
\hline & $\%$ & typering & trend \\
\hline \multicolumn{4}{|l|}{ Bedrijfsgrootte } \\
\hline 5 tot 10 & 49 & gemiddeld & constant \\
\hline 10 tot 20 & 67 & gemiddeld & sterk stijgend \\
\hline 20 tot 100 & 77 & hoog & stijgend \\
\hline 100 tot 500 & - & hoog & sterk dalend \\
\hline 500 of meer & 40 & laag & - \\
\hline \multicolumn{4}{|l|}{ Beroep } \\
\hline Pedagogische beroepen & 64 & gemiddeld & sterk stijgend \\
\hline Culturele beroepen & 88 & hoog & stijgend \\
\hline Agrarische beroepen & - & laag & dalend \\
\hline Technische en Industrieberoepen & 68 & gemiddeld & stijgend \\
\hline Transportberoepen & - & erg laag & constant \\
\hline Medische en Paramedische beroepen & - & gemiddeld & sterk stijgend \\
\hline Economisch-administratieve beroepen & 95 & erg hoog & stijgend \\
\hline Informaticaberoepen & 100 & erg hoog & stijgend \\
\hline Sociaal-culturele beroepen & 99 & erg hoog & stijgend \\
\hline Verzorgende en Dienstverlenende beroepen & 17 & erg laag & stijgend \\
\hline Openbare orde- en Veiligheidsberoepen & 71 & hoog & sterk stijgend \\
\hline \multicolumn{4}{|l|}{ Opleiding } \\
\hline Basisonderwijs & 18 & erg laag & sterk stijgend \\
\hline VMBO Theorie & 65 & gemiddeld & stijgend \\
\hline VMBO Landbouw en techniek & 40 & laag & dalend \\
\hline VMBO Economie & & laag & sterk stijgend \\
\hline VMBO Verzorging & 27 & laag & sterk stijgend \\
\hline HAVO/ VWO & 68 & gemiddeld & sterk stijgend \\
\hline MBO Landbouw en techniek & 68 & gemiddeld & constant \\
\hline MBO Economie & 86 & hoog & stijgend \\
\hline MBO Dienstverlening en gezondheidszorg & 43 & laag & sterk stijgend \\
\hline HO Landbouw en techniek & 96 & erg hoog & constant \\
\hline HO Economie & 96 & erg hoog & sterk stijgend \\
\hline HO Onderwijs en sociaal cultureel & 92 & erg hoog & stijgend \\
\hline $\mathrm{HO}$ (Para)medisch & - & hoog & - \\
\hline
\end{tabular}

Bron: EBB (CBS) 
Ontwikkelingen in de structuur van de werkgelegenheid

Tabel 11.9

Uitstroomrisico, gemiddeld jaarlijks percentage, 1994-1998

$\%$

typering

Beroep

Pedagogische beroepen

Culturele beroepen

Agrarische beroepen

Technische en industrieberoepen

Transportberoepen

Medische en paramedische beroepen

Economisch-administratieve beroepen

Informaticaberoepen

Sociaal-culturele beroepen

Verzorgende en dienstverlenende beroepen

Openbare orde en veiligheidsberoepen

0,0

$1,6 \quad$ laag

8,9

5,0

7,4

14,3

4,2

2,6

2,6
7,4

11,8

0,0

Opleiding

Basisonderwijs

VMBO theorie

VMBO overig

HAVO/VWO

MBO

$\mathrm{HBO}$

WO

$\begin{aligned} 14,9 & \text { erg hoog } \\ 8,0 & \text { hoog } \\ 8,7 & \text { hoog } \\ 7,7 & \text { gemiddeld } \\ 6,4 & \text { gemiddeld } \\ 3,5 & \text { gemiddeld } \\ 0,6 & \text { laag }\end{aligned}$

hoog

gemiddeld

gemiddeld

erg hoog

gemiddeld

laag

gemiddeld

erg hoog

-

laag

Bron: SEP (CBS) 


\section{Scholingsinspanningen}

Tabel 11.10

Deelname aan bedrijfsopleidingen, 2000 (momentopname)

\begin{tabular}{|c|c|c|c|}
\hline & $\%$ & typering & trend \\
\hline \multicolumn{4}{|l|}{ Beroep } \\
\hline Pedagogische beroepen & - & erg hoog & sterk stijgend \\
\hline Culturele beroepen & - & laag & sterk stijgend \\
\hline Agrarische beroepen & - & erg hoog & sterk stijgend \\
\hline Technische en Industrieberoepen & 7 & gemiddeld & sterk stijgend \\
\hline Transportberoepen & - & erg laag & sterk stijgend \\
\hline Medische en Paramedische beroepen & - & erg laag & - \\
\hline Economisch-administratieve beroepen & 6 & gemiddeld & sterk stijgend \\
\hline Informaticaberoepen & 13 & erg hoog & stijgend \\
\hline Sociaal-culturele beroepen & - & erg hoog & constant \\
\hline Verzorgende en Dienstverlenende beroepen & 2 & erg laag & stijgend \\
\hline Openbare orde- en Veiligheidsberoepen & - & erg hoog & sterk stijgend \\
\hline \multicolumn{4}{|l|}{ Opleiding } \\
\hline Basisonderwijs & - & erg laag & sterk stijgend \\
\hline VMBO Theorie & - & gemiddeld & sterk stijgend \\
\hline VMBO Landbouw en techniek & - & gemiddeld & sterk stijgend \\
\hline VMBO Economie & - & erg laag & - \\
\hline VMBO Verzorging & - & erg laag & sterk stijgend \\
\hline HAVO/ VWO & - & erg laag & stijgend \\
\hline MBO Landbouw en techniek & 8 & hoog & stijgend \\
\hline MBO Economie & 6 & laag & sterk stijgend \\
\hline MBO Dienstverlening en gezondheidszorg & - & laag & sterk stijgend \\
\hline HO Landbouw en techniek & 11 & erg hoog & sterk stijgend \\
\hline HO Economie & 9 & erg hoog & sterk stijgend \\
\hline HO Onderwijs en sociaal cultureel & - & laag & sterk stijgend \\
\hline $\mathrm{HO}$ (Para)medisch & - & erg laag & - \\
\hline
\end{tabular}

Bron: EBB (CBS)

\section{Doelgroepen voor scholingsbeleid}

Tabel 11.11

Risicogroepen binnen de sector per risicofactor

$\begin{array}{ll}\text { Lichamelijke belasting } & - \\ \text { Beroep } & - \\ \text { Opleiding } & - \\ \begin{array}{l}\text { Psychische belasting } \\ \text { Beroep }\end{array} & - \\ \text { Opleiding } & - \\ \begin{array}{l}\text { Informatisering } \\ \text { Beroep }\end{array} & - \\ \text { Opleiding } & \\ \begin{array}{l}\text { Ontwikkelingen in de structuur van de werkgelegenheid } \\ \text { Beroep }\end{array} & \text { Verzorgende en dienstverlenende beroepen } \\ \text { Opleiding } & \text { Medische en paramedische beroepen }\end{array}$

Bron: ROA 


\section{Kwartaire diensten}



Tabel 12.1

Kernindicatoren

\section{Arbeidsomstandigheden}

Belastende arbeidsomstandigheden

$\begin{array}{rr}\% & \text { typering } \\ & \\ 15 & \text { laag } \\ 5 & \text { laag } \\ 46 & \text { gemiddeld } \\ 53 & \text { gemiddeld } \\ 55 & \text { gemiddeld } \\ & \\ 8 & \text { gemiddeld } \\ 7 & \text { hoog }\end{array}$

Lawaai

Trilling

Kracht zetten

Beeldschermwerk

Tijdsdruk

$$
\text { hoog }
$$

\section{Technologische en organisatorische ontwikkelingen}

\begin{tabular}{|c|c|c|c|c|c|c|c|}
\hline Organisatorische ontwikkelingen & \multicolumn{2}{|c|}{$1992-1994^{*}$} & \multicolumn{2}{|c|}{$1994-1996 *$} & \multicolumn{2}{|c|}{$1996-1998^{*}$} & $1992-1998^{*}$ \\
\hline Kleine veranderingen & & 18 & & 20 & & 18 & 9 \\
\hline Intensieve veranderingen & & 9 & & 12 & & 13 & 6 \\
\hline Veranderingen in positie & & 6 & & 57 & & 12 & 12 \\
\hline Interne reorganisaties & & 21 & & 32 & & 36 & 15 \\
\hline \multicolumn{2}{|l|}{ Technologische ontwikkelingen } & 1997 & 1998 & 1999 & 2000 & 2001 & $1997-2001^{*}$ \\
\hline \multirow{2}{*}{\multicolumn{2}{|c|}{$\begin{array}{l}\text { FTE's ICT-personeel } \\
\text { Reële automatiseringskosten (euro) }\end{array}$}} & 0,48 & 0,47 & 0,71 & 0,80 & 0,87 & 16 \\
\hline & & 60200 & 59900 & 71200 & 72300 & 76500 & 6 \\
\hline \multirow{4}{*}{$\begin{array}{l}\text { Aantal PC's } \mathrm{s}^{* *} \\
\text { Aantal PC's in netwerk } \\
\text { Aantal internet-PC's }{ }^{* *} \\
\text { (verandering 1998-2001) }\end{array}$} & & 27 & 30 & 37 & 41 & 44 & 13 \\
\hline & & 20 & 23 & 29 & 33 & 38 & 16 \\
\hline & & - & 6 & 12 & 18 & 24 & 55 \\
\hline & 1994 & 1995 & 1996 & 1997 & 1998 & 1999 & 1994-1999* \\
\hline Reële R\&D uitgaven & 1146 & 1152 & 1173 & 1206 & 1230 & 1242 & \\
\hline
\end{tabular}

Ontwikkelingen in de structuur van de werkgelegenheid

Uitstroomrisico, 1994-1998*

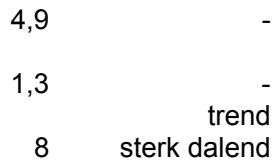

Flexibele arbeid, percentage 2000

\section{Scholingsdeelname}

Deelname aan bedrijfsopleidingen, percentage 2000 (momentopname)
Cursusparticipatie, percentage 1998-2000

48

Bron: K\&E, POLS, Automatiseringsstatistieken (allen CBS), Arbeidsaanbod- en arbeidsvraagpanel (beiden OSA), POA (ROA)

* Gemiddelde jaarlijkse percentages

** Aantal per bedrijf 


\section{Risicoprofiel}

Figuur 12.1

Sectoraal risicoprofiel

\section{Kwartaire diensten}

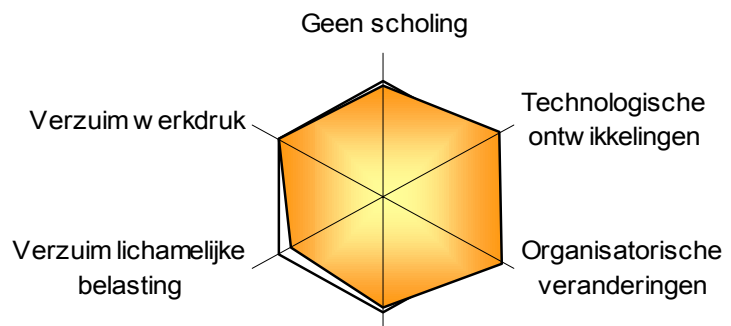

Uitstroomrisico

\section{Arbeidsomstandigheden}

Tabel 12.2

Percentage werkenden dat wordt geconfronteerd met lawaai tijdens het werk, 2000

\begin{tabular}{|c|c|c|c|}
\hline & $\%$ & typering & trend \\
\hline \multicolumn{4}{|l|}{ Bedrijfsgrootte } \\
\hline 5 tot 10 & 15 & laag & sterk stijgend \\
\hline 10 tot 20 & 17 & gemiddeld & sterk stijgend \\
\hline 20 tot 100 & 14 & laag & stijgend \\
\hline 500 of meer & - & hoog & - \\
\hline \multicolumn{4}{|l|}{ Beroep } \\
\hline Pedagogische beroepen & - & gemiddeld & sterk stijgend \\
\hline Culturele beroepen & 19 & gemiddeld & sterk stijgend \\
\hline Agrarische beroepen & - & gemiddeld & - \\
\hline Technische en Industrieberoepen & 40 & erg hoog & sterk stijgend \\
\hline Transportberoepen & - & laag & - \\
\hline Medische en Paramedische beroepen & 11 & laag & constant \\
\hline Economisch-administratieve beroepen & 8 & erg laag & sterk stijgend \\
\hline Informaticaberoepen & - & erg laag & - \\
\hline Sociaal-culturele beroepen & 15 & laag & stijgend \\
\hline Verzorgende en Dienstverlenende beroepen & 19 & gemiddeld & constant \\
\hline Openbare orde- en Veiligheidsberoepen & - & erg laag & - \\
\hline \multicolumn{4}{|l|}{ Opleiding } \\
\hline Basisonderwijs & 12 & laag & stijgend \\
\hline VMBO Theorie & - & laag & sterk dalend \\
\hline VMBO Landbouw en techniek & 22 & gemiddeld & sterk stijgend \\
\hline VMBO Economie & - & erg laag & - \\
\hline VMBO Verzorging & 13 & laag & sterk stijgend \\
\hline HAVO/ VWO & 22 & gemiddeld & sterk stijgend \\
\hline MBO Landbouw en techniek & 27 & hoog & sterk stijgend \\
\hline MBO Economie & 9 & laag & stijgend \\
\hline MBO Dienstverlening en gezondheidszorg & 18 & gemiddeld & constant \\
\hline HO Landbouw en techniek & 14 & laag & sterk stijgend \\
\hline HO Economie & - & erg laag & sterk stijgend \\
\hline HO Onderwijs en sociaal cultureel & 14 & laag & constant \\
\hline HO (Para)medisch & 9 & laag & sterk stijgend \\
\hline
\end{tabular}

Bron: EBB (CBS), bewerking ROA 
Tabel 12.3

Percentage werkenden dat gebruik maakt van gereedschap of apparaten die trilling veroorzaken, 2000

\begin{tabular}{|c|c|c|c|}
\hline & $\%$ & typering & trend \\
\hline \multicolumn{4}{|l|}{ Bedrijfsgrootte } \\
\hline 5 tot 10 & 8 & gemiddeld & sterk stijgend \\
\hline 10 tot 20 & 5 & laag & sterk stijgend \\
\hline 20 tot 100 & 5 & laag & stijgend \\
\hline \multicolumn{4}{|l|}{ Beroep } \\
\hline Pedagogische beroepen & - & laag & - \\
\hline Culturele beroepen & - & laag & - \\
\hline Agrarische beroepen & - & erg hoog & sterk stijgend \\
\hline Technische en Industrieberoepen & 30 & erg hoog & stijgend \\
\hline Transportberoepen & - & gemiddeld & - \\
\hline Medische en Paramedische beroepen & 8 & gemiddeld & sterk stijgend \\
\hline Economisch-administratieve beroepen & - & laag & sterk stijgend \\
\hline Informaticaberoepen & - & laag & - \\
\hline Sociaal-culturele beroepen & - & laag & constant \\
\hline Verzorgende en Dienstverlenende beroepen & 3 & laag & stijgend \\
\hline Openbare orde- en Veiligheidsberoepen & - & laag & - \\
\hline \multicolumn{4}{|l|}{ Opleiding } \\
\hline Basisonderwijs & - & gemiddeld & sterk stijgend \\
\hline VMBO Theorie & - & laag & sterk stijgend \\
\hline VMBO Landbouw en techniek & 22 & hoog & sterk stijgend \\
\hline VMBO Economie & - & hoog & - \\
\hline VMBO Verzorging & - & laag & - \\
\hline HAVO/ VWO & - & laag & sterk dalend \\
\hline MBO Landbouw en techniek & 17 & gemiddeld & sterk stijgend \\
\hline MBO Economie & - & laag & sterk stijgend \\
\hline MBO Dienstverlening en gezondheidszorg & 3 & laag & constant \\
\hline HO Landbouw en techniek & - & gemiddeld & constant \\
\hline HO Economie & - & laag & - \\
\hline HO Onderwijs en sociaal cultureel & - & laag & - \\
\hline HO (Para)medisch & 8 & gemiddeld & sterk stijgend \\
\hline
\end{tabular}

Bron: EBB (CBS) 
Tabel 12.4

Percentage werkenden dat kracht moet zetten tijdens het werk, 2000

\begin{tabular}{|c|c|c|c|}
\hline & $\%$ & typering & trend \\
\hline \multicolumn{4}{|l|}{ Bedrijfsgrootte } \\
\hline 5 tot 10 & 29 & gemiddeld & sterk stijgend \\
\hline 10 tot 20 & 42 & gemiddeld & stijgend \\
\hline 20 tot 100 & 49 & hoog & stijgend \\
\hline 500 of meer & - & gemiddeld & - \\
\hline \multicolumn{4}{|l|}{ Beroep } \\
\hline Pedagogische beroepen & - & laag & sterk stijgend \\
\hline Culturele beroepen & - & erg laag & sterk dalend \\
\hline Agrarische beroepen & - & hoog & - \\
\hline Technische en Industrieberoepen & 52 & hoog & constant \\
\hline Transportberoepen & - & gemiddeld & stijgend \\
\hline Medische en Paramedische beroepen & 56 & hoog & stijgend \\
\hline Economisch-administratieve beroepen & 12 & laag & sterk stijgend \\
\hline Informaticaberoepen & & erg laag & - \\
\hline Sociaal-culturele beroepen & 24 & laag & sterk stijgend \\
\hline Verzorgende en Dienstverlenende beroepen & 77 & erg hoog & stijgend \\
\hline Openbare orde- en Veiligheidsberoepen & - & gemiddeld & - \\
\hline \multicolumn{4}{|l|}{ Opleiding } \\
\hline Basisonderwijs & 57 & hoog & sterk stijgend \\
\hline VMBO Theorie & 48 & hoog & constant \\
\hline VMBO Landbouw en techniek & 56 & hoog & sterk stijgend \\
\hline VMBO Economie & - & erg hoog & sterk stijgend \\
\hline VMBO Verzorging & 73 & erg hoog & stijgend \\
\hline HAVO/VWO & 29 & gemiddeld & stijgend \\
\hline MBO Landbouw en techniek & 38 & gemiddeld & sterk stijgend \\
\hline MBO Economie & 19 & laag & stijgend \\
\hline MBO Dienstverlening en gezondheidszorg & 68 & erg hoog & constant \\
\hline HO Landbouw en techniek & - & erg laag & sterk dalend \\
\hline HO Economie & - & erg laag & sterk stijgend \\
\hline HO Onderwijs en sociaal cultureel & 23 & laag & stijgend \\
\hline HO (Para)medisch & 52 & hoog & sterk stijgend \\
\hline
\end{tabular}

Bron: EBB (CBS) 
Tabel 12.5

Percentage werkenden dat onder hoge tijdsdruk werkt, 2000

$\% \quad$ typering trend

Bedrijfsgrootte

5 tot 10

10 tot 20

20 tot 100

500 of meer

$\begin{array}{lll}52 & \text { laag } & \text { constant } \\ 61 & \text { gemiddeld } & \text { constant } \\ 69 & \text { hoog } & \text { constant } \\ 47 & \text { erg laag } & -\end{array}$

Beroep

Pedagogische beroepen

Culturele beroepen

Agrarische beroepen

Technische en Industrieberoepen

Transportberoepen

Medische en Paramedische beroepen

Economisch-administratieve beroepen

Informaticaberoepen

Sociaal-culturele beroepen

Verzorgende en Dienstverlenende beroepen

Openbare orde- en Veiligheidsberoepen

$\begin{array}{rll}62 & \text { gemiddeld } & \text { stijgend } \\ 77 & \text { erg hoog } & \text { sterk stijgend } \\ - & \text { laag } & \text { sterk dalend } \\ 61 & \text { gemiddeld } & \text { constant } \\ - & \text { erg laag } & \text { constant } \\ 72 & \text { hoog } & \text { constant } \\ 67 & \text { hoog } & \text { stijgend } \\ 80 & \text { erg hoog } & \text { stijgend } \\ 64 & \text { gemiddeld } & \text { stijgend } \\ 59 & \text { gemiddeld } & \text { constant } \\ - & \text { erg laag } & \text { sterk stijgend }\end{array}$

Opleiding

Basisonderwijs

VMBO Theorie

VMBO Landbouw en techniek

VMBO Economie

VMBO Verzorging

HAVO/ VWO

MBO Landbouw en techniek

MBO Economie

MBO Dienstverlening en gezondheidszorg

HO Landbouw en techniek

HO Economie

$\mathrm{HO}$ Onderwijs en sociaal cultureel

HO (Para)medisch

laag
gemiddeld
erg laag
laag
laag
hoog
gemiddeld
gemiddeld
hoog
erg hoog
hoog
hoog
erg hoog

sterk stijgend

dalend

dalend

sterk stijgend

constant

sterk stijgend

sterk stijgend

constant

dalend

constant

constant

constant

constant

Bron: EBB (CBS) 
Tabel 12.6

Percentage werkenden dat als gevolg van klachten door lichamelijke belasting het werk heeft verzuimd, 1999

typering

Beroep

Pedagogische beroepen

Culturele beroepen

Agrarische beroepen

Technische en Industrieberoepen

Transportberoepen

Medische en Paramedische beroepen

Economisch-administratieve beroepen

Informaticaberoepen

Sociaal-culturele beroepen

Verzorgende en Dienstverlenende beroepen

erg laag

laag

erg laag

12 hoog

erg hoog

gemiddeld

gemiddeld

hoog

gemiddeld

erg hoog

Opleiding

Basisonderwijs

VMBO Theorie

VMBO Landbouw en techniek

VMBO Economie

VMBO Verzorging

HAVO/ VWO

MBO Landbouw en techniek

MBO Economie

MBO Dienstverlening en gezondheidszorg

$\mathrm{HO}$ Landbouw en techniek

HO Economie

HO Onderwijs en sociaal cultureel

$\mathrm{HO}$ (Para)medisch

erg hoog

erg laag

gemiddeld

erg laag

laag

gemiddeld

erg laag

erg hoog

hoog

gemiddeld

erg laag

laag

laag

Bron: POLS (CBS) 
Tabel 12.7

Percentage werkenden dat als gevolg van problemen met de werkdruk het werk heeft verzuimd, 1999

$\% \quad$ typering

Beroep

Pedagogische beroepen

Culturele beroepen

Agrarische beroepen

Technische en Industrieberoepen

Transportberoepen

Medische en Paramedische beroepen

Economisch-administratieve beroepen

Informaticaberoepen

Sociaal-culturele beroepen

Verzorgende en Dienstverlenende beroepen

Opleiding

Basisonderwijs

VMBO Theorie

VMBO Landbouw en techniek

VMBO Economie

VMBO Verzorging

HAVO/ VWO

MBO Landbouw en techniek

MBO Economie

MBO Dienstverlening en gezondheidszorg

$\mathrm{HO}$ Landbouw en techniek

HO Economie

$\mathrm{HO}$ Onderwijs en sociaal cultureel

HO (Para)medisch

erg laag

erg laag

erg laag

gemiddeld

erg laag

hoog

gemiddeld

erg laag

erg hoog

hoog

Bron: POLS (CBS) 
Technologische en organisatorische ontwikkelingen

Tabel 12.8

Informatisering, 2000

\begin{tabular}{|c|c|c|c|}
\hline & $\%$ & typering & trend \\
\hline \multicolumn{4}{|l|}{ Bedrijfsgrootte } \\
\hline 5 tot 10 & 65 & gemiddeld & stijgend \\
\hline 10 tot 20 & 49 & gemiddeld & stijgend \\
\hline 20 tot 100 & 54 & gemiddeld & constant \\
\hline 100 tot 500 & - & laag & - \\
\hline 500 of meer & - & laag & - \\
\hline \multicolumn{4}{|l|}{ Beroep } \\
\hline Pedagogische beroepen & 62 & gemiddeld & constant \\
\hline Culturele beroepen & 75 & hoog & sterk stijgend \\
\hline Agrarische beroepen & - & erg laag & sterk dalend \\
\hline Technische en Industrieberoepen & 39 & laag & sterk dalend \\
\hline Transportberoepen & - & erg laag & - \\
\hline Medische en Paramedische beroepen & 58 & gemiddeld & constant \\
\hline Economisch-administratieve beroepen & 94 & erg hoog & stijgend \\
\hline Informaticaberoepen & 100 & erg hoog & sterk stijgend \\
\hline Sociaal-culturele beroepen & 68 & gemiddeld & sterk stijgend \\
\hline Verzorgende en Dienstverlenende beroepen & 13 & erg laag & constant \\
\hline Openbare orde- en Veiligheidsberoepen & - & hoog & dalend \\
\hline \multicolumn{4}{|l|}{ Opleiding } \\
\hline Basisonderwijs & 22 & erg laag & sterk stijgend \\
\hline VMBO Theorie & 45 & gemiddeld & dalend \\
\hline VMBO Landbouw en techniek & 34 & laag & sterk stijgend \\
\hline VMBO Economie & - & erg laag & - \\
\hline VMBO Verzorging & 14 & erg laag & sterk stijgend \\
\hline HAVO/ VWO & 67 & gemiddeld & stijgend \\
\hline MBO Landbouw en techniek & 56 & gemiddeld & stijgend \\
\hline MBO Economie & 82 & hoog & stijgend \\
\hline MBO Dienstverlening en gezondheidszorg & 36 & laag & dalend \\
\hline HO Landbouw en techniek & 88 & hoog & dalend \\
\hline HO Economie & 94 & erg hoog & sterk stijgend \\
\hline HO Onderwijs en sociaal cultureel & 71 & hoog & stijgend \\
\hline HO (Para)medisch & 67 & gemiddeld & stijgend \\
\hline
\end{tabular}

Bron: EBB (CBS) 
Ontwikkelingen in de structuur van de werkgelegenheid

Tabel 12.9

Uitstroomrisico, gemiddeld jaarlijks percentage, 1994-1998

typering

Beroep

Pedagogische beroepen

gemiddeld

Culturele beroepen

Agrarische beroepen

Technische en industrieberoepen

Transportberoepen

Medische en paramedische beroepen

Economisch-administratieve beroepen

Informaticaberoepen

Sociaal-culturele beroepen

Verzorgende en dienstverlenende beroepen

$9,4 \quad$ hoog

0,0

gemiddeld

0,0

3,1

gemiddeld

gemiddeld

0,0

0,0

3,7
8,7

gemiddeld

Opleiding

Basisonderwijs

VMBO theorie

7,9 hoog

VMBO overig

6,4 gemiddeld

HAVO/VWO

hoog

MBO

10,3

$\mathrm{HBO}$

hoog

gemiddeld

WO

gemiddeld

2,1 laag

Bron: SEP (CBS) 


\section{Scholingsinspanningen}

Tabel 12.10

Deelname aan bedrijfsopleidingen, 2000 (momentopname)

\begin{tabular}{|c|c|c|c|}
\hline & $\%$ & typering & trend \\
\hline \multicolumn{4}{|l|}{ Beroep } \\
\hline Pedagogische beroepen & - & gemiddeld & sterk stijgend \\
\hline Culturele beroepen & - & erg laag & sterk stijgend \\
\hline Agrarische beroepen & - & erg laag & - \\
\hline Technische en Industrieberoepen & - & erg laag & sterk dalend \\
\hline Transportberoepen & - & erg laag & - \\
\hline Medische en Paramedische beroepen & 7 & hoog & dalend \\
\hline Economisch-administratieve beroepen & 5 & erg laag & sterk stijgend \\
\hline Informaticaberoepen & - & erg hoog & sterk stijgend \\
\hline Sociaal-culturele beroepen & 5 & laag & sterk stijgend \\
\hline Verzorgende en Dienstverlenende beroepen & 6 & laag & stijgend \\
\hline Openbare orde- en Veiligheidsberoepen & - & erg hoog & sterk dalend \\
\hline \multicolumn{4}{|l|}{ Opleiding } \\
\hline Basisonderwijs & - & erg laag & sterk stijgend \\
\hline VMBO Theorie & - & gemiddeld & sterk dalend \\
\hline VMBO Landbouw en techniek & - & gemiddeld & dalend \\
\hline VMBO Economie & - & erg laag & - \\
\hline VMBO Verzorging & - & erg laag & sterk dalend \\
\hline HAVO/ VWO & - & laag & constant \\
\hline MBO Landbouw en techniek & - & erg laag & sterk dalend \\
\hline MBO Economie & - & laag & sterk stijgend \\
\hline MBO Dienstverlening en gezondheidszorg & 7 & hoog & stijgend \\
\hline HO Landbouw en techniek & - & laag & stijgend \\
\hline HO Economie & - & erg laag & sterk dalend \\
\hline HO Onderwijs en sociaal cultureel & 6 & laag & sterk stijgend \\
\hline $\mathrm{HO}$ (Para)medisch & 6 & gemiddeld & sterk stijgend \\
\hline
\end{tabular}

Bron: EBB (CBS)

\section{Doelgroepen voor scholingsbeleid}

Tabel 12.11

Risicogroepen binnen de sector per risicofactor

\begin{tabular}{|c|c|}
\hline $\begin{array}{l}\text { Lichamelijke belasting } \\
\text { Beroep }\end{array}$ & Transportberoepen \\
\hline Opleiding & - \\
\hline $\begin{array}{l}\text { Psychische belasting } \\
\text { Beroep }\end{array}$ & - \\
\hline Opleiding & MBO economie \\
\hline $\begin{array}{l}\text { Informatisering } \\
\text { Beroep }\end{array}$ & $\begin{array}{l}\text { Economisch- administratieve beroepen } \\
\text { Culturele beroepen }\end{array}$ \\
\hline Opleiding & $\mathrm{HO}$ economie \\
\hline $\begin{array}{l}\text { Ontwikkelingen in de structuur van de werkgelegenheid } \\
\text { Beroep }\end{array}$ & - \\
\hline Opleiding & - \\
\hline
\end{tabular}

Bron: ROA 
13. Overheid en Onderwijs 

Tabel 13.1

Kernindicatoren

\section{Arbeidsomstandigheden}

Belastende arbeidsomstandigheden

$\%$

typering

Lawaai

Trilling

Kracht zetten

Beeldschermwerk

Tijdsdruk

Verzuim vanwege lichamelijke belasting, percentage 1999

Verzuim vanwege de hoge werkdruk, percentage 1999

\section{Technologische en organisatorische ontwikkelingen}

Organisatorische ontwikkelingen

$1992-1994^{*}$

1994-1996*

$1996-1998$

$1992-1998$

Kleine veranderingen

Intensieve veranderingen

Veranderingen in positie

Interne reorganisaties

Technologische ontwikkelingen

FTE's ICT-personee

Reële automatiseringskosten (euro)

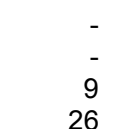

18

$26-21$

$\begin{array}{lllll}1997 & 1998 & 1999 & 2000 & 2001\end{array}$

$\begin{array}{lllll}1,56 & 1,43 & 1,45 & 1,58 & 1,63\end{array}$

$\begin{array}{rrrrr}182900 & 229400 & 219600 & 225300 & 229000\end{array}$

gemiddeld

6

laag

hoog

gemiddeld

4
6

laag

hoog

Aantal PC's**

Aantal PC's in netwerk**

Aantal internet-PC's ${ }^{* *}$

$\begin{array}{rrrrr}78 & 88 & 95 & 107 & 118 \\ 59 & 72 & 73 & 85 & 100\end{array}$

$59 \quad 72$

85

100

(verandering 1998-2001)

$\begin{array}{rrrrr}59 & 42 & 73 & 85 & 100 \\ - & 43 & 46 & 62 & 78\end{array}$

$\begin{array}{lrrrrrr} & 1994 & 1995 & 1996 & 1997 & 1998 & 1999 \\ \text { Reële R\&D uitgaven } & 1636 & 1700 & 1752 & 1778 & 1750 & 1765\end{array}$

1,1

8 trend

Flexibele arbeid, percentage 2000

typering

9

erg hoog

Deelname aan bedrijfsopleidingen, percentage 2000 (momentopname)

62

Bron: K\&E, POLS, Automatiseringsstatistieken (allen CBS), Arbeidsaanbod- en arbeidsvraagpanel (beiden OSA), POA (ROA)

* Gemiddelde jaarlijkse percentages

** Aantal per bedrijf 


\section{Risicoprofiel}

Figuur 13.1

Sectoraal risicoprofiel

Overheid en onderwijs

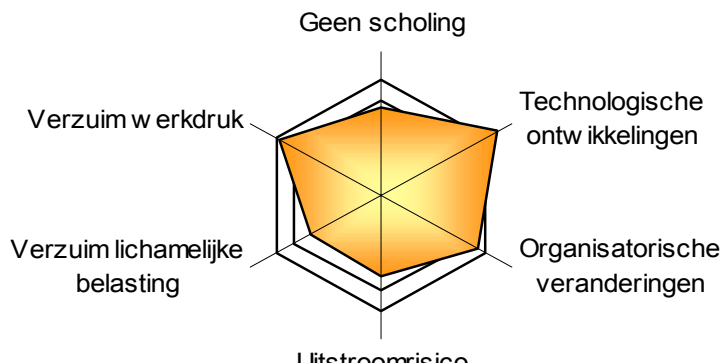

Uitstroomrisico
Technologische

ontw ikkelingen

Organisatorische veranderingen

\section{Arbeidsomstandigheden}

Tabel 13.2

Percentage werkenden dat wordt geconfronteerd met lawaai tijdens het werk, 2000

\begin{tabular}{|c|c|c|c|}
\hline & $\%$ & typering & trend \\
\hline \multicolumn{4}{|l|}{ Bedrijfsgrootte } \\
\hline 5 tot 10 & - & gemiddeld & sterk stijgend \\
\hline 10 tot 20 & 27 & hoog & sterk stijgend \\
\hline 20 tot 100 & 20 & gemiddeld & stijgend \\
\hline \multicolumn{4}{|l|}{ Beroep } \\
\hline Pedagogische beroepen & 37 & erg hoog & sterk stijgend \\
\hline Culturele beroepen & - & laag & sterk stijgend \\
\hline Agrarische beroepen & 37 & erg hoog & stijgend \\
\hline Technische en Industrieberoepen & 25 & gemiddeld & stijgend \\
\hline Transportberoepen & - & gemiddeld & sterk dalend \\
\hline Medische en Paramedische beroepen & - & gemiddeld & sterk stijgend \\
\hline Economisch-administratieve beroepen & 10 & laag & sterk stijgend \\
\hline Informaticaberoepen & - & erg laag & - \\
\hline Sociaal-culturele beroepen & 14 & laag & sterk stijgend \\
\hline Verzorgende en Dienstverlenende beroepen & - & laag & sterk dalend \\
\hline Openbare orde- en Veiligheidsberoepen & 20 & gemiddeld & sterk stijgend \\
\hline \multicolumn{4}{|l|}{ Opleiding } \\
\hline Basisonderwijs & 21 & gemiddeld & sterk stijgend \\
\hline VMBO Theorie & - & erg laag & sterk dalend \\
\hline VMBO Landbouw en techniek & 33 & erg hoog & sterk stijgend \\
\hline VMBO Economie & - & erg laag & - \\
\hline VMBO Verzorging & - & erg laag & - \\
\hline HAVO/ VWO & - & laag & sterk stijgend \\
\hline MBO Landbouw en techniek & 21 & gemiddeld & constant \\
\hline MBO Economie & 11 & laag & sterk stijgend \\
\hline MBO Dienstverlening en gezondheidszorg & 28 & hoog & sterk stijgend \\
\hline HO Landbouw en techniek & 13 & laag & sterk stijgend \\
\hline HO Economie & 7 & erg laag & sterk stijgend \\
\hline HO Onderwijs en sociaal cultureel & 32 & hoog & stijgend \\
\hline $\mathrm{HO}$ (Para)medisch & - & gemiddeld & sterk stijgend \\
\hline
\end{tabular}

Bron: EBB (CBS), bewerking ROA 
Tabel 13.3

Percentage werkenden dat gebruik maakt van gereedschap of apparaten die trilling veroorzaken, 2000

\begin{tabular}{|c|c|c|c|}
\hline & $\%$ & typering & trend \\
\hline \multicolumn{4}{|l|}{ Bedrijfsgrootte } \\
\hline 10 tot 20 & 3 & laag & dalend \\
\hline 20 tot 100 & 6 & laag & constant \\
\hline \multicolumn{4}{|l|}{ Beroep } \\
\hline Pedagogische beroepen & 2 & laag & sterk dalend \\
\hline Culturele beroepen & - & gemiddeld & - \\
\hline Agrarische beroepen & 53 & erg hoog & sterk stijgend \\
\hline Technische en Industrieberoepen & 22 & hoog & dalend \\
\hline Transportberoepen & - & gemiddeld & - \\
\hline Medische en Paramedische beroepen & - & laag & - \\
\hline Economisch-administratieve beroepen & - & laag & sterk stijgend \\
\hline Informaticaberoepen & - & gemiddeld & - \\
\hline Sociaal-culturele beroepen & - & laag & - \\
\hline Verzorgende en Dienstverlenende beroepen & - & gemiddeld & sterk stijgend \\
\hline Openbare orde- en Veiligheidsberoepen & 11 & gemiddeld & sterk stijgend \\
\hline \multicolumn{4}{|l|}{ Opleiding } \\
\hline Basisonderwijs & 30 & erg hoog & sterk stijgend \\
\hline VMBO Theorie & & laag & sterk stijgend \\
\hline VMBO Landbouw en techniek & 22 & hoog & dalend \\
\hline VMBO Economie & - & gemiddeld & - \\
\hline VMBO Verzorging & - & gemiddeld & - \\
\hline HAVO/ VWO & - & laag & sterk stijgend \\
\hline MBO Landbouw en techniek & 14 & gemiddeld & dalend \\
\hline MBO Economie & - & laag & sterk stijgend \\
\hline MBO Dienstverlening en gezondheidszorg & - & laag & sterk stijgend \\
\hline HO Landbouw en techniek & - & laag & stijgend \\
\hline HO Economie & - & laag & - \\
\hline HO Onderwijs en sociaal cultureel & - & laag & sterk dalend \\
\hline $\mathrm{HO}$ (Para)medisch & - & laag & - \\
\hline
\end{tabular}

Bron: EBB (CBS) 
Tabel 13.4

Percentage werkenden dat kracht moet zetten tijdens het werk, 2000

\begin{tabular}{|c|c|c|c|}
\hline & $\%$ & typering & trend \\
\hline \multicolumn{4}{|l|}{ Bedrijfsgrootte } \\
\hline 10 tot 20 & 16 & laag & sterk stijgend \\
\hline 20 tot 100 & 16 & laag & constant \\
\hline \multicolumn{4}{|l|}{ Beroep } \\
\hline Pedagogische beroepen & 11 & erg laag & dalend \\
\hline Culturele beroepen & - & laag & sterk stijgend \\
\hline Agrarische beroepen & 65 & erg hoog & stijgend \\
\hline Technische en Industrieberoepen & 38 & gemiddeld & constant \\
\hline Transportberoepen & 56 & hoog & dalend \\
\hline Medische en Paramedische beroepen & - & laag & sterk stijgend \\
\hline Economisch-administratieve beroepen & 5 & erg laag & sterk stijgend \\
\hline Informaticaberoepen & 23 & laag & sterk stijgend \\
\hline Sociaal-culturele beroepen & - & erg laag & sterk stijgend \\
\hline Verzorgende en Dienstverlenende beroepen & 51 & hoog & stijgend \\
\hline Openbare orde- en Veiligheidsberoepen & 33 & gemiddeld & stijgend \\
\hline \multicolumn{4}{|l|}{ Opleiding } \\
\hline Basisonderwijs & 52 & hoog & sterk stijgend \\
\hline VMBO Theorie & 17 & laag & constant \\
\hline VMBO Landbouw en techniek & 43 & gemiddeld & constant \\
\hline VMBO Economie & - & laag & - \\
\hline VMBO Verzorging & - & gemiddeld & sterk stijgend \\
\hline HAVO/ VWO & - & erg laag & constant \\
\hline MBO Landbouw en techniek & 34 & gemiddeld & constant \\
\hline MBO Economie & 9 & erg laag & sterk stijgend \\
\hline MBO Dienstverlening en gezondheidszorg & 18 & laag & sterk stijgend \\
\hline HO Landbouw en techniek & 6 & erg laag & sterk stijgend \\
\hline HO Economie & - & erg laag & sterk stijgend \\
\hline HO Onderwijs en sociaal cultureel & 10 & erg laag & constant \\
\hline $\mathrm{HO}$ (Para)medisch & - & laag & stijgend \\
\hline
\end{tabular}

Bron: EBB (CBS) 
Tabel 13.5

Percentage werkenden dat onder hoge tijdsdruk werkt, 2000

\begin{tabular}{|c|c|c|c|}
\hline & $\%$ & typering & trend \\
\hline \multicolumn{4}{|l|}{ Bedrijfsgrootte } \\
\hline 5 tot 10 & 49 & laag & sterk stijgend \\
\hline 10 tot 20 & 57 & gemiddeld & sterk stijgend \\
\hline 20 tot 100 & 64 & gemiddeld & dalend \\
\hline 500 of meer & 50 & laag & - \\
\hline \multicolumn{4}{|l|}{ Beroep } \\
\hline Pedagogische beroepen & 65 & gemiddeld & constant \\
\hline Culturele beroepen & 43 & erg laag & sterk dalend \\
\hline Agrarische beroepen & - & erg laag & sterk dalend \\
\hline Technische en Industrieberoepen & 49 & laag & sterk dalend \\
\hline Transportberoepen & - & erg laag & sterk dalend \\
\hline Medische en Paramedische beroepen & 73 & erg hoog & sterk stijgend \\
\hline Economisch-administratieve beroepen & 64 & gemiddeld & dalend \\
\hline Informaticaberoepen & 68 & hoog & dalend \\
\hline Sociaal-culturele beroepen & 76 & erg hoog & stijgend \\
\hline Verzorgende en Dienstverlenende beroepen & 44 & erg laag & constant \\
\hline Openbare orde- en Veiligheidsberoepen & 63 & gemiddeld & constant \\
\hline \multicolumn{4}{|l|}{ Opleiding } \\
\hline Basisonderwijs & 38 & erg laag & constant \\
\hline VMBO Theorie & 50 & laag & sterk dalend \\
\hline VMBO Landbouw en techniek & 39 & erg laag & dalend \\
\hline VMBO Economie & - & erg laag & sterk dalend \\
\hline VMBO Verzorging & - & erg laag & stijgend \\
\hline HAVO/ VWO & 54 & laag & sterk dalend \\
\hline MBO Landbouw en techniek & 58 & gemiddeld & dalend \\
\hline MBO Economie & 60 & gemiddeld & dalend \\
\hline MBO Dienstverlening en gezondheidszorg & 58 & gemiddeld & dalend \\
\hline HO Landbouw en techniek & 72 & hoog & dalend \\
\hline HO Economie & 73 & erg hoog & dalend \\
\hline HO Onderwijs en sociaal cultureel & 67 & hoog & constant \\
\hline HO (Para)medisch & 71 & hoog & stijgend \\
\hline
\end{tabular}

Bron: EBB (CBS) 
Tabel 13.6

Percentage werkenden dat als gevolg van klachten door lichamelijke belasting het werk heeft verzuimd, 1999

$\%$

typering

Beroep

Pedagogische beroepen

Culturele beroepen

Agrarische beroepen

Technische en Industrieberoepen

Transportberoepen

Medische en Paramedische beroepen

Economisch-administratieve beroepen

Informaticaberoepen

Sociaal-culturele beroepen

Verzorgende en Dienstverlenende beroepen

Openbare orde- en Veiligheidsberoepen

$3 \quad$ laag

laag

- $\quad$ erg laag

10 hoog

- $\quad$ erg laag

erg laag

laag

15 erg hoog

9 gemiddeld

erg laag

gemiddeld

Opleiding

Basisonderwijs

VMBO Theorie

VMBO Landbouw en techniek

VMBO Economie

VMBO Verzorging

HAVO/ VWO

MBO Landbouw en techniek

MBO Economie

MBO Dienstverlening en gezondheidszorg

HO Landbouw en techniek

HO Economie

$\mathrm{HO}$ Onderwijs en sociaal cultureel

HO (Para)medisch

laag

laag

erg hoog

erg laag

erg laag

gemiddeld

gemiddeld

laag

gemiddeld

erg laag

laag

laag

erg laag

Bron: POLS (CBS) 
Tabel 13.7

Percentage werkenden dat als gevolg van problemen met de werkdruk het werk heeft verzuimd, 1999

$\% \quad$ typering

Beroep

Pedagogische beroepen

Culturele beroepen

Agrarische beroepen

Technische en Industrieberoepen

Transportberoepen

Medische en Paramedische beroepen

Economisch-administratieve beroepen

Informaticaberoepen

Sociaal-culturele beroepen

Verzorgende en Dienstverlenende beroepen

Openbare orde- en Veiligheidsberoepen

Opleiding

Basisonderwijs

VMBO Theorie

VMBO Landbouw en techniek

VMBO Economie

VMBO Verzorging

HAVO/ VWO

MBO Landbouw en techniek

MBO Economie

MBO Dienstverlening en gezondheidszorg

$\mathrm{HO}$ Landbouw en techniek

HO Economie

HO Onderwijs en sociaal cultureel

HO (Para)medisch

hoog

erg laag

erg laag

gemiddeld

erg laag

erg hoog

gemiddeld

erg hoog

erg hoog

erg hoog

gemiddeld

erg hoog

hoog

laag

erg laag

erg laag

erg laag

hoog

erg hoog

gemiddeld

erg hoog

gemiddeld

hoog

erg laag

Bron: POLS (CBS) 
Technologische en organisatorische ontwikkelingen

Tabel 13.8

Informatisering, 2000

\begin{tabular}{|c|c|c|c|}
\hline & $\%$ & typering & trend \\
\hline \multicolumn{4}{|l|}{ Bedrijfsgrootte } \\
\hline 5 tot 10 & 52 & gemiddeld & sterk stijgend \\
\hline 10 tot 20 & 55 & gemiddeld & sterk stijgend \\
\hline 20 tot 100 & 83 & hoog & dalend \\
\hline 100 tot 500 & - & erg laag & - \\
\hline 500 of meer & - & gemiddeld & - \\
\hline \multicolumn{4}{|l|}{ Beroep } \\
\hline Pedagogische beroepen & 57 & gemiddeld & dalend \\
\hline Culturele beroepen & 88 & hoog & sterk dalend \\
\hline Agrarische beroepen & 37 & laag & constant \\
\hline Technische en Industrieberoepen & 65 & gemiddeld & sterk dalend \\
\hline Transportberoepen & - & erg laag & sterk dalend \\
\hline Medische en Paramedische beroepen & 76 & hoog & constant \\
\hline Economisch-administratieve beroepen & 97 & erg hoog & constant \\
\hline Informaticaberoepen & 100 & erg hoog & stijgend \\
\hline Sociaal-culturele beroepen & 97 & erg hoog & dalend \\
\hline Verzorgende en Dienstverlenende beroepen & - & erg laag & sterk stijgend \\
\hline Openbare orde- en Veiligheidsberoepen & 81 & hoog & stijgend \\
\hline \multicolumn{4}{|l|}{ Opleiding } \\
\hline Basisonderwijs & 38 & laag & stijgend \\
\hline VMBO Theorie & 83 & hoog & dalend \\
\hline VMBO Landbouw en techniek & 59 & gemiddeld & constant \\
\hline VMBO Economie & - & gemiddeld & - \\
\hline VMBO Verzorging & - & laag & stijgend \\
\hline HAVO/ VWO & 91 & erg hoog & sterk dalend \\
\hline MBO Landbouw en techniek & 79 & hoog & constant \\
\hline MBO Economie & 93 & erg hoog & stijgend \\
\hline MBO Dienstverlening en gezondheidszorg & 82 & hoog & dalend \\
\hline HO Landbouw en techniek & 93 & erg hoog & stijgend \\
\hline HO Economie & 95 & erg hoog & dalend \\
\hline HO Onderwijs en sociaal cultureel & 65 & gemiddeld & dalend \\
\hline HO (Para)medisch & 70 & gemiddeld & constant \\
\hline
\end{tabular}

Bron: EBB (CBS) 
Ontwikkelingen in de structuur van de werkgelegenheid

Tabel 13.9

Uitstroomrisico, gemiddeld jaarlijks percentage, 1994-1998

$\%$

typering

Beroep

gemiddeld

Pedagogische beroepen

Culturele beroepen

Agrarische beroepen

Technische en industrieberoepen

Transportberoepen

Medische en paramedische beroepen

Economisch-administratieve beroepen

Informaticaberoepen

Sociaal-culturele beroepen

Verzorgende en dienstverlenende beroepen

Openbare orde en veiligheidsberoepen

3,9

12,5

Opleiding

Basisonderwijs

VMBO theorie

VMBO overig

$\mathrm{HAVO} / \mathrm{VWO}$

MBO

$\mathrm{HBO}$

WO

Bron: SEP (CBS)
8,8

5,6

1,7

4,5

2,2

2,0

4,1

4,3

5,3

hoog

gemiddeld

laag

erg hoog

gemiddeld

laag

laag

gemiddeld

gemiddeld

gemiddeld

$\begin{array}{ll}2,0 & \text { laag } \\ 4,5 & \text { gemiddeld } \\ 7,2 & \text { gemiddeld } \\ 3,2 & \text { gemiddeld } \\ 2,8 & \text { gemiddeld } \\ 2,9 & \text { gemiddeld } \\ 3,7 & \text { gemiddeld }\end{array}$

gemiddeld

gemiddeld

gemiddeld 


\section{Scholingsinspanningen}

Tabel 13.10

Deelname aan bedrijfsopleidingen, 2000 (momentopname)

\begin{tabular}{|c|c|c|c|}
\hline & $\%$ & typering & trend \\
\hline \multicolumn{4}{|l|}{ Beroep } \\
\hline Pedagogische beroepen & 8 & erg hoog & sterk stijgend \\
\hline Culturele beroepen & - & erg laag & dalend \\
\hline Agrarische beroepen & - & hoog & sterk stijgend \\
\hline Technische en Industrieberoepen & 10 & erg hoog & stijgend \\
\hline Transportberoepen & - & erg hoog & sterk dalend \\
\hline Medische en Paramedische beroepen & - & erg laag & constant \\
\hline Economisch-administratieve beroepen & 9 & erg hoog & sterk stijgend \\
\hline Informaticaberoepen & - & erg hoog & sterk stijgend \\
\hline Sociaal-culturele beroepen & - & hoog & sterk stijgend \\
\hline Verzorgende en Dienstverlenende beroepen & - & laag & sterk stijgend \\
\hline Openbare orde- en Veiligheidsberoepen & 12 & erg hoog & dalend \\
\hline \multicolumn{4}{|l|}{ Opleiding } \\
\hline Basisonderwijs & - & gemiddeld & dalend \\
\hline VMBO Theorie & - & hoog & sterk dalend \\
\hline VMBO Landbouw en techniek & - & gemiddeld & sterk dalend \\
\hline VMBO Economie & - & erg hoog & stijgend \\
\hline VMBO Verzorging & - & erg hoog & sterk stijgend \\
\hline HAVO/ VWO & - & gemiddeld & dalend \\
\hline MBO Landbouw en techniek & 13 & erg hoog & sterk stijgend \\
\hline MBO Economie & 8 & hoog & sterk stijgend \\
\hline MBO Dienstverlening en gezondheidszorg & - & hoog & stijgend \\
\hline HO Landbouw en techniek & 8 & hoog & sterk stijgend \\
\hline HO Economie & 10 & erg hoog & sterk stijgend \\
\hline HO Onderwijs en sociaal cultureel & 9 & erg hoog & sterk stijgend \\
\hline $\mathrm{HO}$ (Para)medisch & - & laag & dalend \\
\hline
\end{tabular}

Bron: EBB (CBS)

\section{Doelgroepen voor scholingsbeleid}

Tabel 13.11

Risicogroepen binnen de sector per risicofactor

$\begin{array}{ll}\begin{array}{l}\text { Lichamelijke belasting } \\ \text { Beroep }\end{array} & - \\ \text { Opleiding } & - \\ \begin{array}{l}\text { Psychische belasting } \\ \text { Beroep }\end{array} & \begin{array}{l}\text { Verzorgende en dienstverlenende beroepen } \\ \text { Medische en paramedische beroepen }\end{array} \\ \text { Opleiding } & - \\ \begin{array}{l}\text { Informatisering } \\ \text { Beroep }\end{array} & - \\ \text { Opleiding } & - \\ \text { Ontwikkelingen in de structuur van de werkgelegenheid } & - \\ \text { Beroep } & - \\ \text { Opleiding }\end{array}$

Bron: ROA 